Pacific Northwest Laboratory

Annual Report for 1988 to

the Assistant Secretary for

Environment, Safety, and Health

Part 5 Environment, Safety, Health, and Quality Assurance February 1989

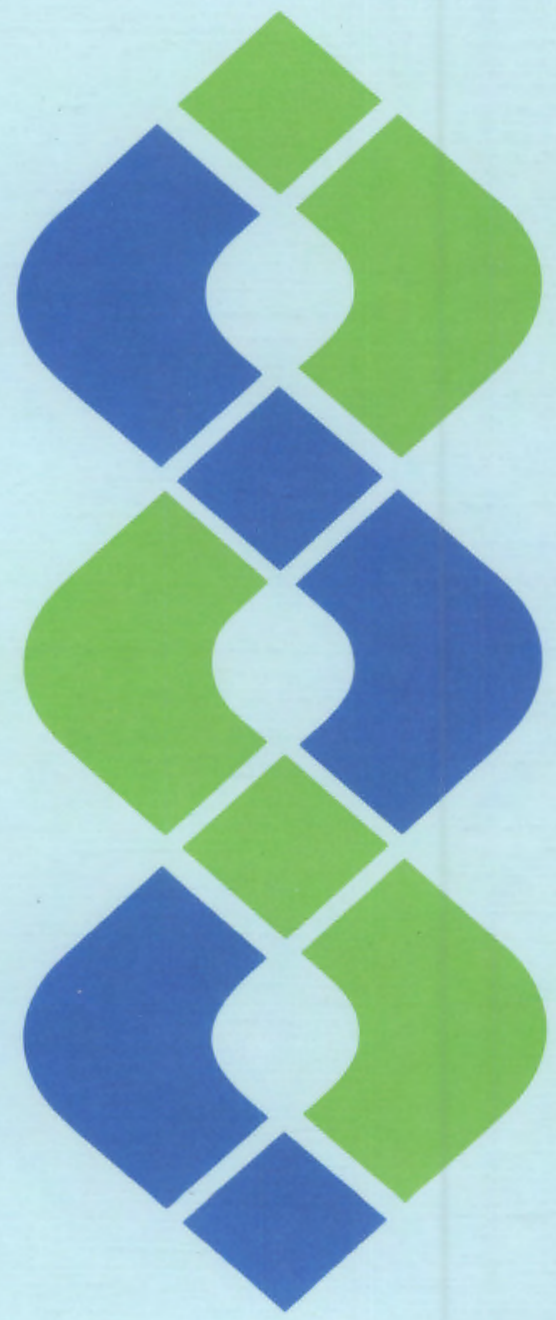

Prepared for the U.S. Department of Energy under Contract DE-AC06-76RLO 1830

Pacific Northwest Laboratory Operated for the U.S. Department of Energy by Battelle Memorial Institute 


\title{
DISCLAIMER
}

This report was prepared as an account of work sponsored by an agency of the United States Government. Neither the United States Government nor any agency thereof, nor Battelle Memorial Institute, nor any or their employees, makes any warranty, expressed or implied, or assumes any legal liability or responsibility for the accuracy, completeness, or usefulness of any information, apparatus, product, or process disclosed, or represents that its use would not infringe privately owned rights. Reference herein to any specific commercial product, process, or service by trade name, trademark, manufacturer, or otherwise does not necessarily constitute or imply its endorsement, recommendation, or favoring by the United States Government or any agency thereof, or Battelle Memorial Institute. The views and opinions of authors expressed herein do not necessarily state or reflect those of the United States Government or any agency thereof.

\author{
PACIFIC NORTHWEST LABORATORY \\ operated by \\ BATTELLE MEMORIAL INSTITUTE \\ for the \\ UNITED STATES DEPARTMENT OF ENERGY \\ under Contract DE-AC06-76RLO 1830
}

\begin{tabular}{|c|c|}
\hline \multicolumn{2}{|c|}{ Printed in the United States of America } \\
\hline & $\begin{array}{c}\text { Available from } \\
\text { National Technical Information Secvice }\end{array}$ \\
\hline \multicolumn{2}{|c|}{ National Technical Information Service } \\
\hline \multicolumn{2}{|c|}{ United States Department of Commerce } \\
\hline \multicolumn{2}{|c|}{5285 Port Royal Road } \\
\hline \multicolumn{2}{|c|}{ Springfield, Virginia 22161} \\
\hline \multicolumn{2}{|c|}{ NTIS Price Codes } \\
\hline \multicolumn{2}{|c|}{ Microfiche A01 } \\
\hline \multicolumn{2}{|c|}{ Printed Copy } \\
\hline & Price \\
\hline Pages & Codes \\
\hline 001-025 & $\mathrm{A} 02$ \\
\hline 026-050 & A03 \\
\hline 051-075 & A04 \\
\hline 076-100 & A05 \\
\hline $101-125$ & A06 \\
\hline $126-150$ & A07 \\
\hline $151-175$ & $\mathrm{~A} 0 \mathrm{~B}$ \\
\hline $176-200$ & A09 \\
\hline 201.225 & A10 \\
\hline $226-250$ & A11 \\
\hline 251-275 & A12 \\
\hline 276-300 & A13 \\
\hline
\end{tabular}




\section{Pacific Northwest Laboratory Annual Report for 1988 to the Assistant Secretary for Environment, Safety, and Health \\ Part 5 Environment, Safety, Health, and Quality Assurance}

L. G. Faust, W. T. Pennell, J. M. Selby, and Staff

February 1989

Prepared for the U.S. Department of Energy under Contract DE-AC06-76RLO 1830 


\section{PREFACE}

This 1988 Annual Report from Pacific Northwest Laboratory (PNL) to the U.S. Department of Energy (DOE) describes research in environment, safety and health conducted during fiscal year 1988 . The report again consists of five parts, each in a separate volume.

The five parts of the report are oriented to particular segments of the PNL program. Parts 1 to 4 report on research performed for the DOE Office of Health and Environmental Research in the Office of Energy Research. Part 5 reports progress on all research performed for the Assistant Secretary for Environment, Safety and Health. In some instances, the volumes report on research funded by other DOE components or by other governmental entities under interagency agreements. Each part consists of project reports authored by scientists from several PNL research departments, reflecting the multidisciplinary nature of the research effort.

The parts of the 1988 Annual Report are:

Part 1: Biomedical Sciences

Program Manager: J. F. Park $\quad$ D. L. Felton, Report Coordinator and Editor

Part 2: Environmental Sciences

Program Manager: R. E. Wildung S. G. Weiss, Report Coordinator and Editor

G. P. O'Connor, Editor

Part 3: Atmospheric Sciences

Program Manager: C. E. Elderkin $\quad$ C. E. Elderkin, Report Coordinator

E. L. Owczarski, Editor

Part 4: Physical Sciences

Program Manager: L. H. Toburen L. H. Toburen, Report Coordinator

K. A. Parnell, Editor

Part 5: Environment, Safety, Health, and Quality Assurance

Program Managers: L. G. Faust

W. T. Pennell

J. M. Selby

L. G. Faust and W. T. Pennell, Report Coordinators

S. K. Ennor, Editor

Activities of the scientists whose work is described in this annual report are broader in scope than the articles indicate. PNL staff have responded to numerous requests from DOE during the year for planning, for service on various task groups, and for special assistance.

Credit for this Annual Report goes to the many scientists who performed the research and wrote the individual project reports, to the program managers who directed the research and coordinated the technical process reports, to the editors who edited the individual project reports and assembled the five parts, and to Ray Baalman, editor in chief, who directed the total effort. 
Members of the Scientific Advisory Committee, established in 1985, are:

Dr. Franklin I. Badgley University of Washington

Dr. Leo K. Bustad Washington State University

Dr. Franklin Hutchinson Yale University

Dr. Albert W. Johnson San Diego State University

Dr. J. Newell Stannard University of Rochester; University of California, San Diego

\author{
W. J. Bair \\ T. S. Tentorde \\ Environment, Health and Safety \\ Research Program
}

Previous reports in this series:

\title{
Annual Report for:
}

\begin{tabular}{|c|c|}
\hline 1951 & $H W-25021, H W-25709$ \\
\hline 1952 & HW-27814, HW-28636 \\
\hline 1953 & $\mathrm{HW}-30437, \mathrm{HW}-30464$ \\
\hline 1954 & HW-30306, HW-33128, HW-35905, HW-35917 \\
\hline 1955 & HW-39558, HW-41315, HW-41500 \\
\hline 1956 & $H W-47500$ \\
\hline 1957 & HW-53500 \\
\hline 1958 & HW-59500 \\
\hline 1959 & HW-63824, HW-65500 \\
\hline 1960 & HW-69500, HW-70050 \\
\hline 1961 & $H W-72500, H W-73337$ \\
\hline 1962 & HW-76000, HW-77609 \\
\hline 1963 & HW-80500, HW-81746 \\
\hline 1964 & BNWL- 122 \\
\hline 1965 & BNWL-280, BNWL 235, Vol. 1-4; BNWL-361 \\
\hline 1966 & BNWL-480, Vol. 1; BNWL-481, Vol. 2, Pt. 1-4 \\
\hline 1967 & BNWL-714, Vol. 1; BNWL-715, Vol, 2, Pt. 1-4 \\
\hline 1968 & BNWL-1050, Vol. 1;, Pt. 1-2; BNWL-1051, Vol, 2, Pt. 1-3 \\
\hline 1969 & BNWL-1306, Vol. 1;, Pt. 1-2; BNWL-1307, Vol. 2, Pt. 1-3 \\
\hline 1970 & BNWL-1550, Vol, 1; Pt. 1-2; BNWL-155:, Vol. 2, Pt. 1-2 \\
\hline 1971 & BNWL-1650, Vol. 1;, Pt. 1-2; BNWL-1651, Vol. 2, Pt. 1-2 \\
\hline 1972 & BNWL-1750, Vol, 1; Pt. 1-2; BNWL-1751, Vol. 2, Pt. 1-2 \\
\hline 1973 & BNWL-1850, Pt. $1-4$ \\
\hline 1974 & BNWL-1950, Pt. $1-4$ \\
\hline 1975 & BNWL-2000, Pt. 1-4 \\
\hline 1976 & BNWL-2100, Pt. 1-5 \\
\hline 1977 & PNL-2500, Pt. $1-5$ \\
\hline 1978 & PNL-2850, Pt. 1-5 \\
\hline 1979 & PNL-3300, Pt. 1-5 \\
\hline 1980 & PNL-3700, Pt. $1-5$ \\
\hline 1981 & PNL-4100, Pt. $1-5$ \\
\hline 1982 & PNL-4600, Pt. $1-5$ \\
\hline 1983 & PNL -5000 , Pt. $1-5$ \\
\hline 1984 & PNL-5500, Pt. 1-5 \\
\hline 1985 & PNL-5750, Pt. 1-5 \\
\hline 1986 & PNL-6100, Pt. 1-5 \\
\hline 1987 & PNL-6500, Pt. $1-5$ \\
\hline
\end{tabular}




\section{FOREWORD}

Part 5 of the 1988 Annual Report to the U.S. Department of Energy's Assistant Secretary for Environment, Safety, and Health presents Pacific Northwest Laboratory's progress on work performed for the Office of Environmental Guidance and Compliance, the Office of Environmental Audit, the Office of National Environmental Policy Act Project Assistance, the Office of Nuclear Safety, the Office of Safety Compliance, and the Office of Policy and Standards. For each project, as identified by the Field Work Proposal, there is an article describing progress made during fiscal year 1988. Authors of these articles represent a broad spectrum of capabilities derived from five of the seven technical centers of the Laboratory, reflecting the interdisciplinary nature of the work. 



\section{CONTENTS}

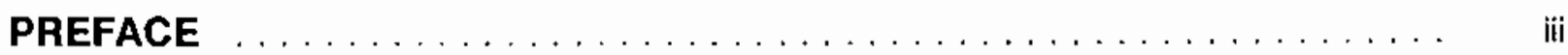

FOREWORD $\ldots \ldots \ldots \ldots \ldots \ldots \ldots \ldots \ldots \ldots \ldots \ldots \ldots \ldots \ldots \ldots \ldots \ldots$

DEPUTY ASSISTANT SECRETARY FOR ENVIRONMENT $\ldots \ldots \ldots \ldots$

Environmental Protection, Support, and Assistance $\ldots \ldots \ldots \ldots \ldots \ldots$

Technical Support to Criteria Development, R. D. Stenner, J. Mishima, W. E. Kennedy, Jr., W. L. Templeton, R. A. Peloquin,

J. K. Soldat, and L. K. Grove . . . . . . . . . . . . . . . . 3

Internal Dose Conversion Tabtes, W. E. Kennedy, Jr.,

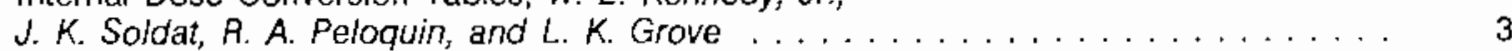

Derived Concentration Guides, W. E. Kennedy, Jr.,

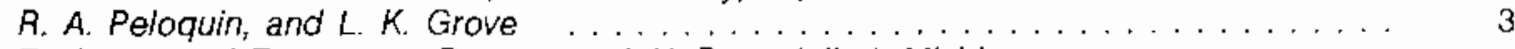

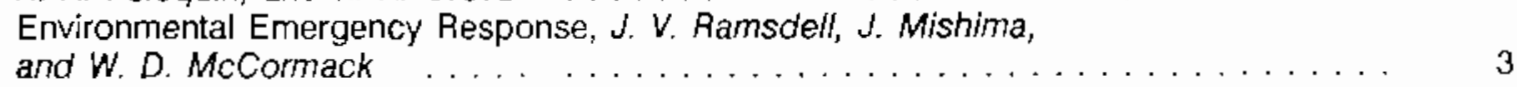

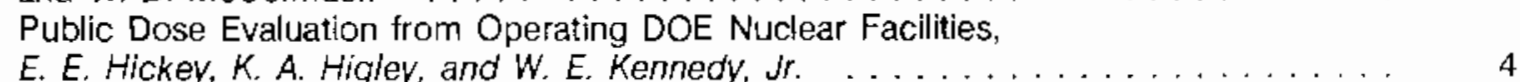

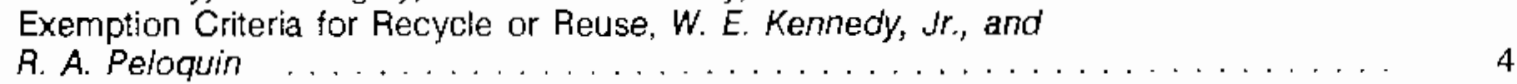

Public and Environmental ALARA and "Best Available Technology"

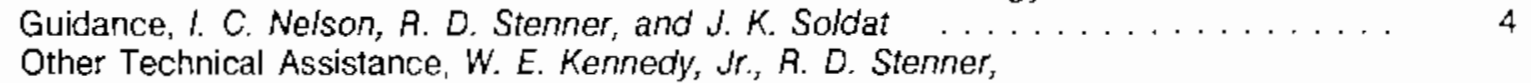

J. K. Soldat, P. E. Bramson, and 1. C. Nelson . . . . . . . . . . . . . 4

Environmental/Hazardous Waste Risk Assessment $\ldots \ldots \ldots \ldots \ldots \ldots$

Enhancement of the Remedial Action Priority System, J. G. Droppo,

G. Whelan, D. L. Strenge, K. A. Higley, J. S. Wilbur, P. G. Doctor,

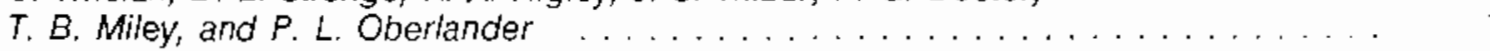

Development of the Multimedia Environmental Pollutant

Assessment Systern Methodology, J. G. Droppo, J.W. Buck,

B. L. Hoopes, M. B. Walter, D. R. Friedrichs, G. Whelan,

D. R. Roth, and K. A. Higley

Technical Support for the Environmental Survey

Environmental Survey Sampling and Analysis Program, J. L. Daniel,

L.J. Kirby, R. A. Owens, S. L. English, E. J. McCoy, G. A. McAtee,

J. L. Latkovich, D. E. Hilmas, J. E. Gebhart, D. W. Raichart,

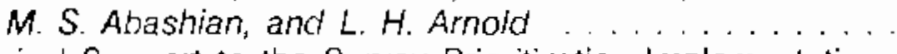

Technical Support to the Survey Prioritization Implementation

Working Group, K. A. Higley, B. L. Steelman, and G. Whelan

Technical Support in Evaluation of Superfund Sites Using

the RAPS Methodology, G. Whelan, K. A. Higley, J. G. Droppo,

D. L. Strenge, B. L. Steelman, M. B. Walter, J. W. Buck,

R. D. Brockhaus, and B. L. Hoopes ..................... 10

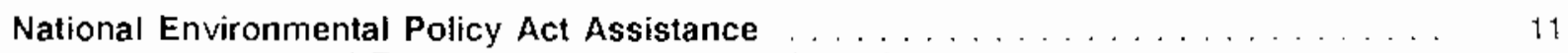

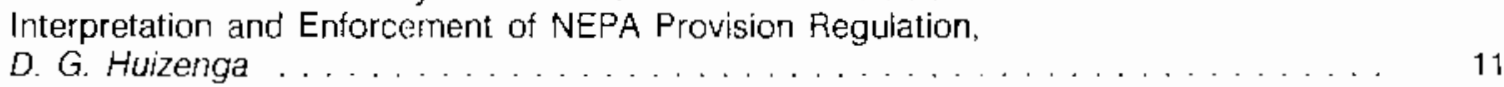

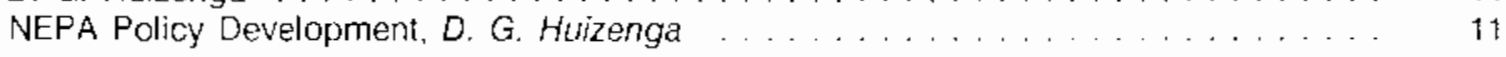


Long-Range Planning Assistance $\ldots \ldots \ldots \ldots \ldots \ldots \ldots \ldots \ldots$

Technical Evaluation, R. G. Schreckhise, T. L. Anderson,

D. A. Baker, D. P. Higby, B. V. Johnston, D. A. Lamar,

D. A. McNeill, M. L. Rosbach, D. R. Simpson, R. D. Sterner,

L. M. Valdez, and W. G. Woodruff . . . . . . . . . . . . . . . . .

DEPUTY ASSISTANT SECRETARY FOR SAFETY, HEALTH,

AND QUALITY ASSURANCE $\ldots \ldots \ldots \ldots \ldots \ldots \ldots \ldots \ldots \ldots \ldots \ldots$

Personnel Neutron Dosimeter Evaluation and Upgrade $\ldots \ldots \ldots \ldots \ldots \ldots \ldots$

Combination Thermoluminescent Dosimeter/Track-Etch Dosimeter,

M. A. Parkhurst, D. E. Hankins (LLNL), J. F. Johnson, and

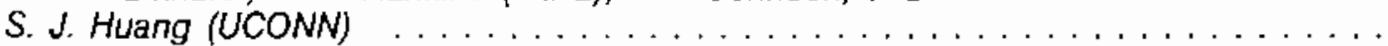

Portable Field Neutron Spectrometer, L. W. Brackenbush,

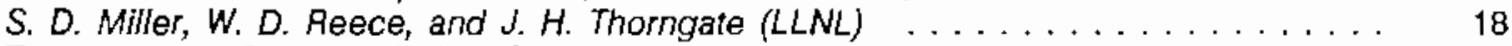

Total Effective Dose Equivalent System, J. E. Tanner,

L. W. Brackenbush, W. D. Reece, and R. I. Scherpelz . . . . . . . . . . . . . 18

Optically Stimulated Luminescent Dosimetry, S. D. Miller . . . . . . . . . . . . . . . . . . 19

Superheated Drop Detector, R. E. Apfel (Apfel Enterprises),

D. R. Sisk, C. M. Stroud, and K. L. Swinth . . . . . . . . . . . . . . . . . 20

Optical Track Detector for Neutron Dosimetry, J. E. Turner (ORNL),

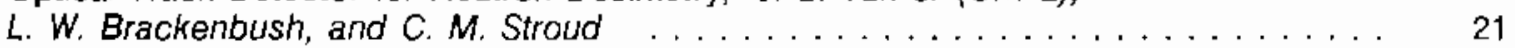

Neutron Depth-Dose Characterization, R. I. Scherpelz . . . . . . . . . . . . . . . 21

Personnel Neutron Dosimetry Assessment, D. E. Hadlock,

L. W. Brackenbush, L. G. Faust, M. A. Parkhurst, and C. M. Stroud . . . . . . . . . 21

Accelerator Health Physics, R. C. McCall (SLAC), L. M. Coulson (Fermi),

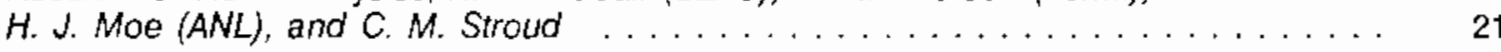

Beta Measurement Evaluation and Upgrade $\ldots \ldots \ldots \ldots \ldots \ldots \ldots \ldots \ldots \ldots$

Beta Dosimeter Development, S. D. Miller, S. E. Merwin,

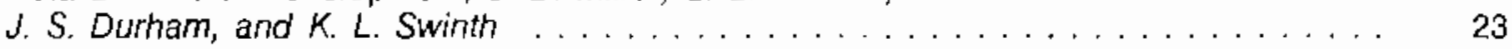

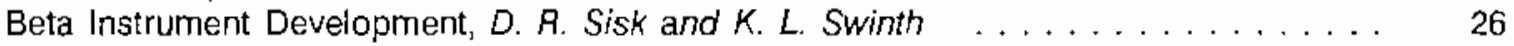

Theoretical Considerations, K. L. Swinth and W. D. Reece . . . . . . . . . . . 26

Health Physics Support and Assistance to the Department

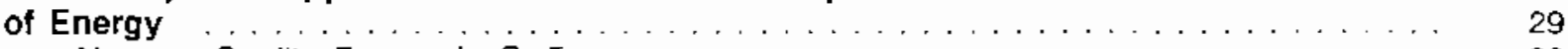

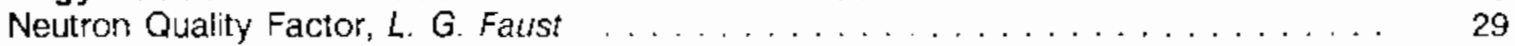

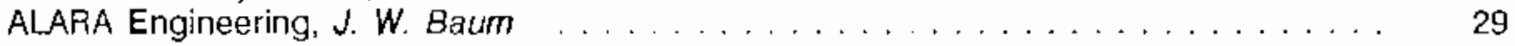

Annual Radiation Exposure Report, S. E. Merwin . . . . . . . . . . . . . . 29

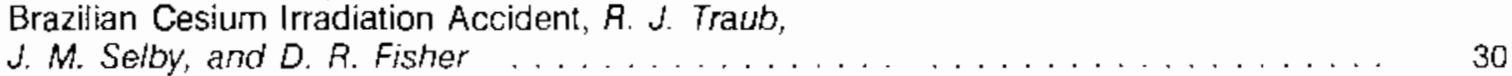

Report on Missed Dose, $R$. J. Traub . . . . . . . . . . . . . . . 30

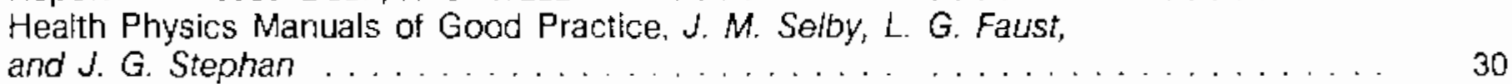

Technical Evaluation of the Capability of Present Instrumentation

to Meet the Requirements of Draft ANSI Standard N42.17,

E. E. Hickey, K. L. Swinth, G. A. Stoezel, D. R. Sisk,

and $M$. R. Tinker

Air Sampling and Monitoring, E. E. Hickey, J. Mishima, J. M. Selby,

and K. L. Swinth

Evaluation and Upgrade of Extremity Dose Measurement at DOE Facilities,

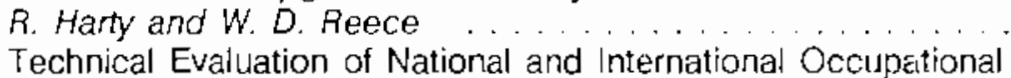

Radiation Exposure Recommendations, Standards, and Regulations,

J. M. Selby and J. G. Stephan

Accreditation of Instrument Performance and Calibration,

K. L. Swinth 
Department of Energy Laboratory Accreditation Program

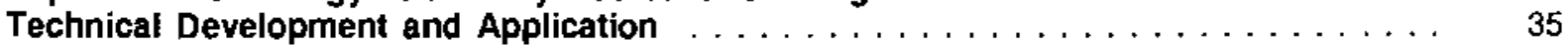

High-Energy Neutron Category, J. C. McDonald and K. L. Jones . . . . . . . . . 35

ICRU 39 Impact Studies, $J$. C. McDonald . . . . . . . . . . . . . . . . . 35

Intercomparison Progress, F. M. Cummings and

J. C. McDonald ... . . . . . . . . . . . . . . . . . . . . . . . . . 36

Angular-Dependence Category, K. L. Jones, R. A. Fox, F. M. Cummings,

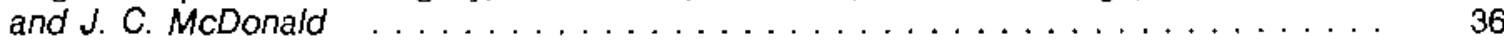

Supplemental Tasks, R. A. Fox, J. C. McDonald, F. M. Cummings,

F. N. Eichner, R. T. Hogan, C. D. Hooker, K. L. Jones, and

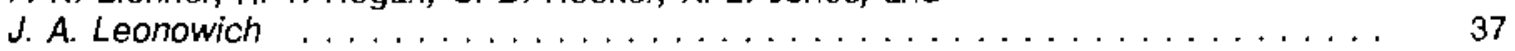

Internal Dosimetry Evaluation and Upgrade $\ldots \ldots \ldots \ldots \ldots \ldots \ldots \ldots$

Guide to Implementation of DOE Orders for Internal Dosimetry,

R. M. Hall and T. R. LaBone (SRP), D. R. Fisher and M. J. Sula (PNL),

J. S. Bogard (ORNL), W. D. Fairman (ANL), R. B. Falk (RFP),

J. D. Foulke (DOE), J. N. P. Lawrence (LANL), E. T. Lessard (BNL),

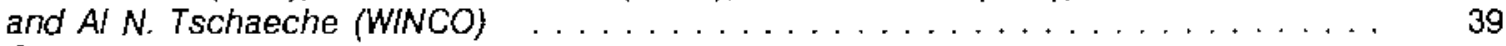

Chemical and Radiological Toxicities of Uranium,

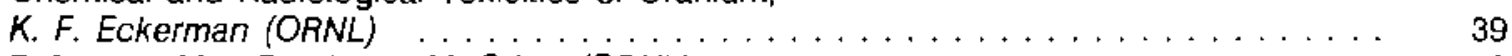

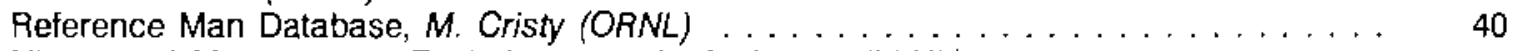

Uttrasound Measurement Techniques, A. L. Anderson (LLNL) . . . . . . . . . . 40

Re-Evaluation of the Human Plutonium Injection Data of 1945-1946,

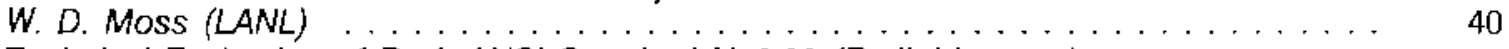

Technical Evaluation of Draft ANSI Standard N13.30 (Radiobioassay),

J. A. MacLellan and R. J. Traub

Measurement of Transuranics in Workers, H. E. Palmer (PNL)

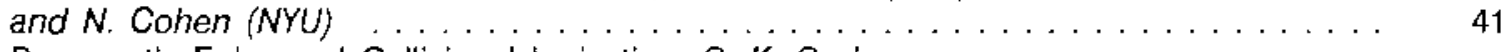

Resonantly Enhanced Collisional lonization, G. K. Gerke,

B. A. Bushaw, and T. J. Whitaker ................... 41

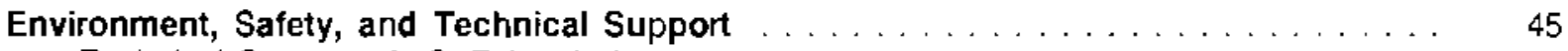

Technical Support, A. S. Tabatabai . . . . . . . . . . . . . . . . . . . 45

PUBLICATIONS $\ldots \ldots \ldots \ldots \ldots \ldots \ldots \ldots \ldots \ldots \ldots \ldots$

PRESENTATIONS $\ldots \ldots \ldots \ldots \ldots \ldots \ldots \ldots \ldots \ldots \ldots \ldots$

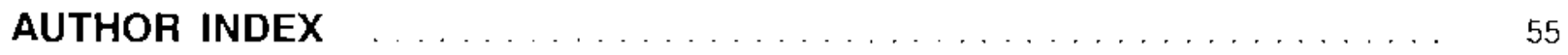

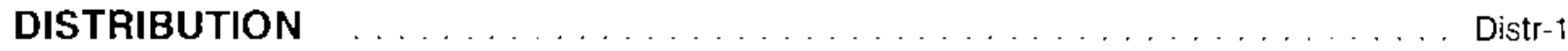





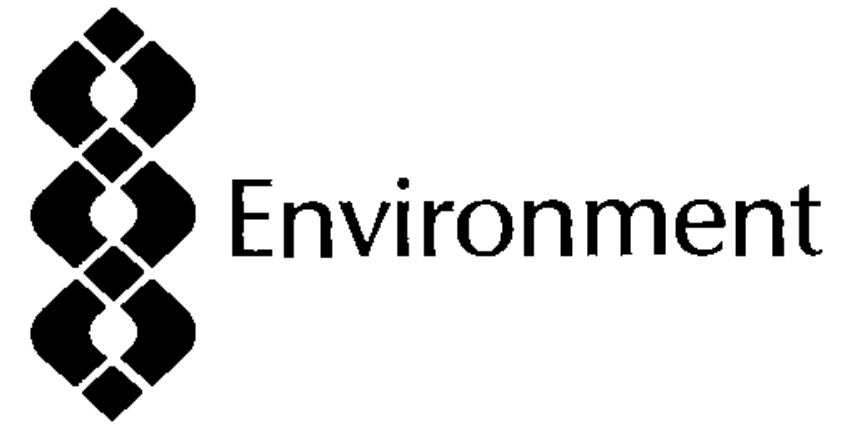




\section{DEPUTY ASSISTANT SECRETARY FOR ENVIRONMENT}

The U.S. Department of Energy (DOE) Deputy Assistant Secretary for Environment ensures that activities and installations of the DOE and its contractors are in full compliance with DOE environmental protection policies and applicable federal, state, and local environmental standards and regulations. The Deputy Assistant Secretary for Environment provides technical support and oversight to DOE programs and ensures that all DOE-controlled activities are conducted in an environmentally responsible manner. Pacific Northwest Laboratory (PNL) has established the following four projects in support of the Deputy Assistant Secretary for Environment's mission:

- Environmental Protection, Support, and Assistance

- Environmental/Hazardous Waste Risk Assessment

- National Environmental Policy Act Assistance

- Long-Range Planning Assistance. 


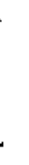




\section{Environmental Protection, Support, and Assistance}

Project Manager: W. E. Kennedy, Jr.

Pacific Northwest Laboratory (PNL) continued to provide technical assistance to the U.S. Department of Energy (DOE) Deputy Assistant Secretary for Environment through a project with the Office of Environmental Guidance and Compliance (OEG\&C). Assistance from PNL included 1) the development and revision of draft technical requirements to support the revised DOE orders concerning environmental protection, 2) development of a final table of dose conversion factors for estimating public radiation exposures, 3) calculation of final Derived Concentration Guides (DCGs) for establishing exposure limits for the public to contaminated air or drinking water, 4) technical support during the development of a revised DOE order for assessing atmospheric release consequences during emergencies at DOE nuclear facilities, 5) development of draft and final summaries of the reported radiation doses to the public from DOE nuclear facilities, and 6) additional support efforts concerning technical reviews and comments on draft public radiation exposure standards and regulations. Progress made in these areas during fiscal year (FY) 1988 is discussed in the following sections.

\section{Technical Support to Criteria Development}

R. D. Stenner, J. Mishima, W. E. Kennedy, Jr., W. L. Templeton, R. A. Peloquin, J. K. Soldat, and L. K. Grove

In support of DOE's development of revised environmental radiological protection order (DOE 5400.3 , Radiation Protection of the Public and the Environment [DOE 1988a]), PNL staff continued to contribute by developing technical criteria in a number of areas. Some of these criteria were included as draft requirements for effluent monitoring and environmental surveillance in the draft revised DOE environmental orders. The technical criteria are those identified in other DOE orders (for consistency within the DOE system), or those identified in other established or pending federal regulations, or those from other sources that represent sound technical practice. In addition, PNL technical experts participated in criteria development efforts with the International Atomic Energy Agency (IAEA) concerning technologies for cleanup activities following nuclear accidents and model validation studies using the Chernobyl data. These support efforts will continue through 1989.

Internal Dose Conversion Tables

W. E. Kennedy, Jr., J. K. Soldat, R. A. Peloquin, and L. K. Grove

The camera-ready text and tables for a document for the DOE Office of Environmental, Health, and Safety (EH) entitled Internal Dose Conversion Factors for Calculation of Dose to the Public (DOE/EH-0071; DOE 1988b) were prepared and delivered to OEG\&C for publication. These tables are intended to support the revised DOE orders on public radiation protection and were published and distributed to the DOE Operations and Programs Offices and key DOE contractor staff. The dose conversion factors (DCFs) are based on the recommendations of the International Commission on Radiological Protection (ICRP) as found in their Publications 26, 30, and 48 (ICRP 1977, 1979, 1986). The required use of these DCFs will help assure that there is consistency among the reported radiation doses estimated for all DOE sites and facilities.

\section{Derived Concentration Guides}

W. E. Kennedy, Jr., R. A. Peloquin, and

L. K. Grove

Final tables of DCGs, in units of $\mu \mathrm{Ci} / \mathrm{mL}$, were developed for public exposure to contaminated air or drinking water. These tables were calculated using the standardized DCFs found in DOE/EH0071 . The tables of DCGs and supporting metabolic data were included as a chapter in DOE 54003 (DOE 1988a). For consistency, Derived Air Concentrations (DACs) were calculated in a similar manner for protecting workers during exposure to contaminated air. Tables of these DAC values will be included in the revised DOE order on occupational radiation protection (i.e., proposed DOE 5480.11).

\section{Environmental Emergency Response}

J. V. Ramsdell, J. Mishima, and W. D. McCormack

Technical assistance was provided to DOE Headquarters $(\mathrm{HO})$ during the revision of the 
emvironmental consequence assessment methods supporting the DOE environmental emergency response orders. The methods focus on meteorological monitoring and prediction following accident situations. Contributors from PNL worked closely with DOE representatives from three separate organizations in developing the initial review draft information. This task is scheduled to be completed during 1989.

\section{Public Dose Evaluation from Operating DOE Nuclear Facilities}

E. E. Hickey, K. A. Higley, and W. E. Kennedy, Jr.

Draft summaries of the reported public radiation doses from operating DOE nuclear facilities for the years 1985 and 1986 were prepared. The information included the reported maximum individual and population doses from $29 \mathrm{DOE}$ sites. This information will be published in fitral form during 1989. A summary paper on public exposures from DOE facilities was presented at an American Nuclear Society meeting on "Population Exposure from the Nuclear Fuel Cycle" held in Oak Ridge, Tennessee, during late 1987. The full paper was published in the meeting proceedings during 1988. Additional efforts to prepare annual dose summary reports will continue during 1989.

\section{Exemption Criteria for Recycle or Reuse}

\section{W. E. Kennedy, Jr., and R. A. Peloquin}

The recycle or reuse of equipment and materials with trace levels of radionuclide contaminants for unrestricted public use is of concern to DOE because of the growing stockpiles at its defense sites. Through this task, PNL was able to provide a technical consultant to the IAEA during the development of draft international exemption criteria for the recycle or reuse of radioactively contaminated materials. The categories of equipment or materials considered included recycle of concrete, aluminum, and steel, and reuse of concrete buildings, tools, or equipment. As part of this task, summary papers were presented at the Seventh International Congress of the International Radiation Protection Association (IRPA) held in Sydney, Australia, and at the 10th Annual DOE Low-Level Radioactive Waste Management Conference in Denver, Colorado. This task is expected to be completed during 1989.

\section{Public and Environmental ALARA and "Best Available Technology" Guidance}

\author{
I. C. Nelson, R. D. Stenner, and J. K. Soldat
}

Because of recent changes in the DOE policies on public and environmental radiation protection, there is a need for uniform guidance in specific areas. Two such areas concern maintaining public and environmental radiation doses as low as reasonably achievable (ALARA) and applying the "Best Available Technology" (BAT) for controlling licuuid effluents. Through this effort, PNL was able to begin initial preparation of technical guidance documents on these subjects. These documents will be distributed in draft form for comment to the DOE Operations and Programs Offices and published during 1989.

\section{Other Technical Assistance}

W. E. Kennedy, Jr., R. D. Stenner, J. K. Soldat, P. E. Brainson, and I. C. Nelson

Through a technical assistance task, PNL further supports OEG\&C by providing rapid-turnaround technical responses or reviews to priority requests. These requests typically are in areas that fall outside the scope of the identified tasks but have an urgency to DOE and its operations. During 1988, these special assistance tasks included: 1) participation in a special Technical Resource Group (TRG) to evaluate potential revisions to 4 J CFR 191, the U.S. Environmental Protection Agency (EPA) high-level radioactive waste regulations, 2) participation in a TRG to evaluate draft 40 CFR 193, the draft EPA low-level waste regulations, 3) participation in a DOE task force to consider uranium waste management, 4) support to individuals contributing to the development of a new lung model for the ICRP, and 5) preparation of review comments on various draft or final technical reports and standards from national and international authorities.

\section{References}

Internatiorial Commission on Radiological Protection (ICRP). 1977. Recommendations of the Interrational Commission on Radiological Protection. ICRP Publication 26, Pergamon Press, New York. New York. 
International Commission on Radiological Protection (ICRP). 1979. Limits for Intakes of Radionuclides by Workers. ICRP Publication 30, Part 1 (and subsequent parts and supplements), Vol. 2, No. 3/4 through Vol. 8, No. 4, Pergamon Press, New York, New York.

International Commission on Radiological Protection (ICRP). 1986. The Metabolism of Plutonium and Related Elements. ICRP Publication 48, Vol. 16, No. 2/3, Pergamon Press, New York, New York.
U.S. Department of Energy (DOE). 1988a. Radiation Protection of the Public and the Environment. DOE 5400.3, U.S. Department of Energy, Washington, D.C.

U.S. Department of Energy (DOE). 1988b. Internal Dose Conversion Factors for Calculation of Dose to the Public. DOE/EH-0071, U.S. Department of Energy, Washington, D.C. 



\title{
Environmental/Hazardous Waste Risk Assessment
}

\author{
Project Manager: J. G. Droppo
}

Pacific Northwest Laboratory (PNL) continues to provide technical guidance and support to the U.S. Department of Energy (DOE) in the environmental/hazardous waste risk assessment area. During fiscal year (FY) 1988, PNL worked with the Office of Environmental Guidance and Compliance (OEG\&C) and the Office of Environmental Audit (OEA) in the area of environmental risk assessment, surveys, and evaluations of environmental problems related to hazardous and radioactive materials. The overall objective of PNL's efforts was to assist DOE in developing technical tools in support of guidance for its operations and to ensure compliance of these operations with applicable environmental regulations and standards. Major efforts during FY 1988 included 1) for OEG\&C, enhancement of the Remedial Action Priority System (RAPS) for ranking inactive waste sites; 2) for OEA, development of the Multimedia Environmental Pollutant Assessment System (MEPAS) for use in ranking issues identified by the DOE Environmental Survey; and 3) for OEA, technical support to the DOE Environmental Survey. Progress made in these areas during FY 1988 is discussed in the following sections.

\section{Enhancement of the Remedial Action Priority System}

J. G. Droppo, G. Whelan, D. L. Strenge, K. A. Higley, J. S. Wilbur, P. G. Doctor, T. B. Miley, and P. L. Oberlander

The Remedial Action Priority System (RAPS) was developed for DOE's Office of Environment, Safety, and Heaith. In response to the environmental survey need for a ranking tool that could evaluate releases from active as well as inactive sites, the RAPS methodology was expanded to include active sites and called the Multimedia Environmental Pollutant Assessment System (MEPAS) methodology. The more descriptive acronym, MEPAS refers to the methodology that is applicable to both active and inactive sites. Because the work reported here was aimed mainly at developing a methodology for inactive sites, the RAPS acronym is used.

During the year, $\mathrm{PNL}$ completed and delivered a new version of the RAPS code and supporting documentation that included a number of new transport and exposure components. New transport components were groundwater mounding, groundwater as a source, groundwater decay at the source, atmospheric complex terrain, atmospheric back-calculation, air as a source, transient atmospheric releases, atmospheric decay at the source and in the environment, and atmospheric mass budget; and indoor air concentration components were added during FY 1988. Work continued on the development of an open water component, sediment transport, and groundwater back-calculation components.
Two new exposure pathways were added to consider volatilization/intake from bathing and direct radiation exposure using measured radiation field information. A new component was added for estimation of fish production rates. An improved transport-to-exposure linkage was added for airto-crops deposition.

The constituent database contains physical, chemical, and toxicological parameters required by the RAPS code for various release, transport, and exposure computations. During FY 1988 approximately 90 new chemicals were added to this database bringing the total number to 351 . Sources of data inputs are mainly IRIS and GEMS, and other available databases and data compilations.

A sensitivity study on the MEPAS code was completed during $F Y 1988$ and a draft report on the study was subrnitted to DOE in September 1988. This study quantified the sensitivity of MEPAS output, ranking parameter values to variations in the input parameters.

During FY 1989, further enhancements will be made to the MEPAS code and training sessions will be conducted for DOE. Elforts will be started to provide a tramework for effective application of the MEPAS methodology in the RI/FS/RA process to potential problems at DOE facilities.

Although MEPAS was devoloped mainly as a ranking tool to compare different sites using a relative health-based ranking index. MEPAS turns out to be a very valuable tool for evaluation of potential problems at a single site. Often the list of constituents of possible concern at a site can 
be quite long. The relative merits of possible remedial actions to deal with potential problems can be difficult to assess. In both cases, the MEPAS methodology provides a consistent physics-based system for ranking potential environmental problems using a health-based approach.

\section{Development of the Multimedia Environmental Pollutant Assessment System Methodology}

J. G. Droppo, J. W. Buck, B. L. Hoopes, M. B. Walter, D. R. Friedrichs, G. Whelan, D. R. Roth, and K. A. Higley

As stated previously, the MEPAS methodology represents an expanded version of the RAPS and is physics-based methodology that uses a relative index of potential health risks for prioritizing potential environmental problems at DOE's facilities. The methodology is based on application of a multimedia environmental transport code coupled with an exposure pathways code. The first operational integrated MEPAS code was delivered to DOE in September 1987.

Over the first half of FY 1988, a high level of technical support was provided to DOE and DOE contractors in the application of the MEPAS methodology to $16 \mathrm{DOE}$ defense program sites. This application was completed in FY 1988.

In July 1988, a second version of interim guidance was provided for use in the environmental survey prioritization eflort. Consisting of facility application summary, input parameter worksheets, and input parameter guidelines, this version of interim guidance updated the September 1987 version to include improved control parameters, new and revised transport and exposure pathways, and definition of the form and format of screens for the user-friendly shell currently under development.

A major effort during FY 1988 was the development of a user-friendly interface for data input and execution of MEPAS runs. The interface was needed to solve a number of problems encountered during the application of MEPAS to the first 16 DOE defense program sites. The intertace provides automatic range checking for input parameters, computation of certain required parameters, access to a database of chemical and physical constituent parameters, definition of the environmental problems to be considered, creation of labeled worksheets of required inputs, and running the selected environmental releases.
In summary, the interface allows for more accurate and timely completion of survey activities.

A second version of an operational, integrated MEPAS code with the user- friendly interface was delivered in September 1988. This represented a major milestone in the delivery of the products needed by the environmental survey to conduct the prioritization process for DOE sites with potential environmental problems.

The majo: effort in FY 1989 will be in providing technical support for the application of MEPAS to 15 additicnal DOE facilities during the first half of FY 1989, and the reapplication of the methodology using environmental survey results in the second half of FY 1989. This technical support will include guidance in model applications, resolution of any code application questions that arise, and completion of the formal documentation of all components of the MEPAS methodology. Training sessions will be provided to DOE and DOE coritractors for different aspects of the methodology application.

\section{Technical Support for the Environmental Survey}

The purpose of the DOE Environmental Survey is to identify and then prioritize, on a DOE-wide basis, environmental issues that require further attention. Three areas where PNL provided technical support to the Survey were: 1) technical support to the field teams, 2) field sampling and laboratory analysis efforts, and 3) technical support to the Survey Prioritization Implementation Working Giroup.

Environmental Survey Sampling and Analysis Program

J. L. Daniel, L. J. Kirby, R. A. Owens, S. L. English, E. J. McCoy, G. A. McAtee, J. L. Latkovich D. E. Hilmas, J. E. Gebhart, D. W. Raichart, M. S. Abashian, and L. H. Arnold

Pacific Northwest Laboratory is one of four national laboratories collaborating on the Environmental Survey Sampling and Analysis (S\&A) Program. The purpose of the S\&A Program is to collect field samples and provide analytical data to assist DOE in identifying environmental problems and areas of environmental risk at DOE facilities. The key activities of the S\&A Program are 1) collection of carefully controlled quantitative laboratory analyses of the 
samples, and 2) reporting of the results to DOE. Work for which PNL is responsible is conducted in Richland, Washington, and Columbus, Ohio.

The program requires careful management and coordination because of the broad diversity of program activities, the requirement for a wide variety of laboratory and field facilities and skills at widespread geographic locations, stringent interlaboratory and interagency regulations and specifications, and the need for close cooperation and responsiveness to the DOE Program Manager and the other three participating DOE laboratories (Argonne National Laboratory, Oak Ridge National Laboratory, and Idaho National Engineering Laboratory [INEL]).

Staff at PNL began work on the program in January 1987. Ultimately, PNL will provide S\&A reports describing findings from each of the assigned DOE sites on a schedule estabilshed by the DOE Program Manager. The program responsibilities have been divided into five major tasks: Site Sampling, Sample Analysis, Special Analytical Problems, Data Management, and Program Technical Assistance. Major accomplishments were achieved during FY 1988.

Full site sampling work was conducted at one DOE site, the Nevada Test Site (NTS) near Las Vegas. In addition, special assignments of well drilling, sampling, and analysis were conducted at the Brookhaven, Pantex, and Argonne sites in support of the other participating laboratories. Field sampling is a key activity. Samples, taken from carefully selected site locations, must be carefully collected, protected, preserved, and transported to the analytical laboratories with regard to strict safety and quality control (QC) considerations. Samples collected at NTS were distributed to Columbus, Oak Ridge, and Argonne for analyses. Audits of the field work were conducted for DOE by representatives of the Environmental Protection Agency (EPA).

Complete laboratory analyses of samples collected at all sarnpling sites were conducted under strict $O C$ specifications established by DOE based on the EPA Contract Laboratory Program (CLP). Participating laboratories were required to maintain established CLP capabilities, demonstrate continuing qualifications by analyses of EPA's quarterly blind-test specimens, and successtully undergo periodic laboratory audits by EPA teams. Several hundred analyses were conducted for specified radiochemical, inorganic, and organic constituents in water, soil, and sediment samples.
Pacific Northwest Laboratory has the additional programmatic responsibility for conducting special analyses of samples posing unusual hazard control problems (e.g., dioxin and PCB analyses, and high-explosive components). The laboratory also provides backup analytical support to the other program laboratories that need additional capacity to meet required schedules. Thus, sample sets from five sites (Sandia-Livermore, Pantex, Portsmouth, INEL, and Kansas City) were analyzed for other participating laboratories under the PNL program.

The major activity of preparing the detailed final reports and supporting analytical data packages for the program was started in FY 1988, and will comprise the primary activity during FY 1989. The computerized data management system developed at Columbus specifically for this program is providing a major contribution to completion of the Survey Program deliverables. Sample reports and analytical data can be output in three different forms for report use: as electronic data tabulations for direct input to PNL's or other participants' data sets; as CLP-format analysis reports directly comparable with manual or laboratorycalculated output; and in final DOE report format. The system is being used extensively in preparing the voluminous final reports for each assigned site, and for data transfer to and from other participating laboratories.

Quality Assurance (QA) is playing a key role in this phase of the program. All report and data packages are QA-reviewed in detail at several stages of preparation: to assure completeness, accuracy, and traceability of all information. The computerized data management system at PNL supports this effort; it is designed to prevent entry errors or omissions from passing through unnoticed into the reports.

The S\&A Program activities will be completed during FY 1989. An intensive effort will be directed toward preparation of the final data documents summatizing all work conducted for the three DOE sites for which PNL has primary responsibility. During this period, special attention must be given to optimizing interactions with the other three participating program laboratories. Much of the supporting data required for PNL's three major documents conies from the other participants' laboratories, while at the same time PNL is contributing significant analytical data on eight other sites to the other participants. 
Also, during $\mathrm{FY} 1989$ a revision of the Environmental Survey Manual will be completed. The revision will be based on new contributions, updates, and corrections to the first edition text issued under PNL's program assignment during FY 1987. Additional backup work may also be assigned by DOE program management in support of preparation of other site data documents.

\section{Technical Support to the Survey Prioritization Implementation Working Group}

\section{K. A. Higley, B. L. Steelman, ${ }^{\left({ }^{2}\right)}$ and G. Whelan}

Pacific Northwest Laboratory provided input to the Survey Prioritization implementation Working Group (SPRIG). The purpose of SPRIG is to provide technical guidance to the Survey Teams regarding the collection, analysis, and interpretation of data obtained during the Environmental Survey. A key aspect of SPRIG was to provide guidance to the teams in colfecting data for use with the MEPAS methodology and to instruct the teams in the approach needed in defining the environmental problem for purposes of applying MEPAS. As the developer of MEPAS, $P N L$ 's role was to ensure that sufficient guidance was provided to the teams and the supporting contractor so that the system would be accurately and consistently applied. Staff at PNL participated in SPRiG meetings each month and took part in discussions, prepared white papers on implementation issues, and provided training for MEPAS implementation.

\section{Technical Support in Evaluation of Superfund Sites Using the RAPS Methodology}

G. Whelan, K. A. Higley, J. G. Droppo, D. L. Strenge, B. L. Steelman, M. B. Walter, J. W. Buck, R. D. Brockhaus, and B. L. Hoopes

The EPA and DOE requested that PNL, using RAPS, participate in an evaluation of inactive waste site ranking systems that were being considered as potential replacements for the EPA's Hazard Ranking System (HRS). The other ranking systems were the New York State Exposure Model, the Hazardous Assessment Ranking Model II, the revised HRS, and an expert panel selectec by EPA. RAPS was used to rank 20 sites that had been placed on the National Priorities List (i.e., Superfund sites).

The results of the RAPS analysis of the 20 sites illustrated the methodology's flexibility in handling a wide variety of complex problems and its ability to provide a basis for comparison throughout the assessment process. RAPS also provides a structure or tramework on which further investigations at a site can be based, at which point it can be used to help focus assessment exercises and indicate where problems potentially exist, why they are occutring, what effects changes can have on the assessment, where to focus available resources (i.e., time and money), and what alternatives may be most effective.

(a) Current address: Ciba-Geigy Corporation, Tomsriver Plant, P.O. Box 71, Tomsriver, New Jersey 08753 


\title{
National Environmental Policy Act Assistance
}

\author{
Project Manager: D. G. Huizenga
}

The National Environmental Policy Act (NEPA) Assistance Project provides onsite technical support for several major projects being reviewed by the U.S. Department of Energy's (DOE) Office of NEPA Project Assistance. The projects under review are supported by the Office of Defense Programs and include the Waste Isolation Pilot Plant in Carlsbad, New Mexico; the proposed Special Isotope Separation Project at the Idaho National Engineering Laboratory; the Plutonium Recovery Modification Project at Rocky Flats; the Special Nuclear Materials Research and Development Laboratory at Los Alamos National Laboratory; and several other projects supporting the DOE plan to modernize the nuclear weapons production complex. Specific tasks include 1) providing guidance to DOE Program and Field Office personnel regarding the interpretation and enforcement of the regulations for implementing the procedural provisions of NEPA and 2) development of overall NEPA policy and guidance. The NEPA Office has requested a continuation of the current support and additional support on an expanded scope of activities, including the New Production Reactor Projects for fiscal year (FY) 1989. Progress made on the two tasks during FY 1988 is discussed in the following sections.

\section{Interpretation and Enforcement of NEPA Provision Regulations}

\section{G. Huizenga}

Through an onsite assignment to DOEHeadquarters, PNL provided guidance to DOE Field Office personnel to better interpret and enforce regulations for implementing NEPA procedural provisions. Guidance is based on regulations issued by the Council on Environmental Quality (CEO), 40 CFR Parts 1500-1508 (as amended), the DOE NEPA guidelines (52 FR 47662-47670), and legal case history. The project staff work closely with personnel in the Office of General Counsel, the Office of Safety, Health, and Quality Assurance, and the Office of Environmental Guidance and Compliance to ensure that all applicable federal, state, and local regulations are adequately addressed in the NEPA documentation under review.

\section{NEPA Policy Development}

\section{G. Huizenga}

In addition to providing technical review of special projects, the NEPA Assistance Project staff support the development of DOE NEPA policy. During $F Y$ 1988, efforts were focused in several areas: 1) developing a strategy to interlace the requirements of NEPA, the Resource Conservation and Recovery Act, the Comprehensive Environmental Response, Compensation, and Liability Act, and the Superfund Amendments and Reauthorization Act; 2) issuing guidance on the treatment of occupational impacts in DOE's NEPA documents; and 3) developing guidance regarding the treatment of accident analysis. Additionally, project staff worked with other personnel in the Office of NEPA Project Assistance to develop and propose an expanded list of NEPA categorical exclusions to be incorporated into the DOE NEPA guidelines. This task is being accomplished through coordination with DOE General Counsel, U.S. Environmental Protection Agency Headquarters, and CEO.

Project staff prepared to participate in a national DOE NEPA workshop on October 25-26, 1988. Presentations included guidance on occupational impacts and analysis of severe accidents.

\section{References}

40 CFR 1500-1508. 1986. Council on Ervironmental Quality, Executive Office of the President, "Regulations for Implementing the Procedural Provisions of the National Environmental Policy Act." U.S. Code of Federal Regulations.

52 FR 47662-47670. December 15,1987 . U.S. Department of Energy, "Compliance with the National Environmental Policy Act (NEPA); Amendments to the DOE NEPA Guidelines." Federal Register. 



\title{
Long-Pange Planning Assistance
}

\author{
Project Manager: R. G. Schreckhise
}

Pacific Northwest Laboratory (PNL) continues to provide technical assistance to the U.S. Department of Energy (DOE) Deputy Assistant Secretary for Environment through a project with the Office of Environmental Guidance and Compliance (OEG\&C). During FY 1988, DOE initiated development of an assessment of the environment, safety, and health needs of all DOE facilities. Assistance from PNL includes technical evaluation of the information provided by the DOE Field Operations Offices, consisting of projections of resource needs and accompanying years to achieve compliance with appropriate environment, safety, and health requirements through the year 2010 and beyond, if additional time is projected. Initial progress made in this area during fiscal year 1988 is discussed below.

\section{Technical Evaluation}

R. G. Schreckhise, T. L. Anderson, D. A. Baker, D. P. Higby, B. V. Johnston, D. A. Lamar, D. A. McNeill, M. L. Rosbach, D. R. Simpson. R. D. Stenner, L. M. Valdez, and W. G. Woodruff

Initial technical evaluation of the information provided by the DOE Field Offices was completed in August 1988. This involved organizational, logistical, editorial, and word processing support.
A database system was developed to manage the information that was provided by the Field Offices. Argonne National Laboratory also provided technical support. The first draft of the associated report entitled, Assessment of Environment, Safety, and Health Needs of the U.S. Department of Energy, will be released for comment in October 1988 and the second draff in November 1988. The final version is scheduled to be presented to Congress by DOE in December 1988. 

Safety, Health, and Quality

Assurance 


\section{DEPUTY ASSISTANT SECRETARY FOR SAFETY, HEALTH, AND QUALITY ASSURANCE}

To establish and maintain an effective radiation protection program, the U.S. Department of Energy (DOE) Deputy Assistant Secretary for Safety, Health, and Quality Assurance has assigned to the Office of Nuclear Safety (ONS) the responsibility for developing an effective applied research and development program and developing and promulgating nuclear safety policy, standards, and guidance. These functions were reassigned during the year to the Office of Safety Compliance (OSC) and the Office of Safety Policy and Standards (OSPS). These offices are also responsible for the conduct of DOE-wide independent overview, support, and counsel in radiation protection. This was all accomplished by various programs that collectively are called the Health Physics Outlay Program. The objectives of the Health Physics Outlay Program are to aid DOE in ensuring that the activities of DOE and its contractors are in full compliance with applicable nuclear safety, health, and emergency preparedness standards and regulations, and to provide technical support to the DOE Assistant Secretary for Environment, Safety, and Health. To accomplish this, Pacific Northwest Laboratory (PNL) was established as a lead laboratory in health physics to conduct the following five projects to assist DOE in achieving its radiation protection mission:

\section{- Personnel Neutron Dosimeter Evaluation and Upgrade}

\section{- Beta Measurement Evaluation and Upgrade}

- Health Physics Support and Assistance to the Department of Energy

- Department of Energy Laboratory Accreditation Program Technical Development and Application

- Internal Dosimetry Evaluation and Upgrade.

The Personnel Neutron Dosimetry Evaluation and Upgrade Project was initiated in October 1980 with PNL as the lead laboratory to: 1) assess current personnel neutron dosimeter capabilities at DOE laboratories, 2) develop improved neutron dosimeters and instrument systems, 3) provide technical coordination of work being conducted by various laboratories, universities, and private companies, 4) maintain program quality and timeliness, and 5) provide leadership in the overall neutron dosimetry field. The short-term goal of the project has been the development of an interim neutron dosimeter and a portable neutron spectrometer for use at DOE facilities. The long-term goal is to develop an effective dose equivalent system for use at DOE laboratories.

The Beta Measurement Evaluation and Upgrade Project focuses on the resolution of problems associated with field measurement of the beta dose at DOE facilities. The change in DOE programs, including increased efforts in improved waste management and decontamination and decommissioning (D\&D) of facilities, coupled with beta measurement problems identified at Three Mile Island, have increased the need to improve beta measurements. In fiscal year (FY) 1982, work was initiated to provide a continuing effor to identify problems associated with beta dose assessment at DOE facilities. The problems identified resulted in the development of this project. During FY 1988, project activities have included: 1) an assessment of measurement systems now in use, 2) field measurements at DOE facilities, 3) the development of improved calibration and evaluation procedures, 4) the application of innovative beta dosimetry concepts, 5) the investigation of new instruments or concepts for monitoring and spectroscopy, and 6) the preparation of a "manual of good practices" to ensure an adequate and uniform beta measurement program at DOE facilities.

The Health Physics Support and Assistance Project provides health physics support and assistance to the ONS (OSPS). Support and assistance has been provided for specific tasks or special studies that have been identified as high priorities by the DOE. The designation of PNL as the lead laboratory in health physics, with an agreement and budget in place, has provided DOE with the additional expertise mecessary to respond to the many questions and situations that arise during the operation of its numerous nuclear energy research, development, and demonstration facilities. 
The Department of Energy Laboratory Accreditation Program Development and Application Project provides research support for the DOE Laboratory Accreditation Program (DOELAP) for personnel dosimetry services. The research effort encompasses the development of improved calibration methods and the operation of intercomparison and measurement assurance projects for DOE laboratories. Major accomplishments for $F Y 1988$ include: 1) development of performance criteria for high-energy neutron dosimeters, 2) investigation of the impact of International Commission on Radiation Units and Measurements Report 39 on DOE calibrations (jointly funded by the Health Physics Support and Assistance Project), 3) operation of a calibration intercomparison program for DOE laboratories, and 4) recommendation of a set of performance criteria for angular response of personnel dosimeters.

The Internal Dosimetry Evaluation and Upgrade Project is a multilaboratory research project that was established to improve internal dosimetry at DOE and DOE-cortractor laboratories. The project has six principal objectives: 1) to identify current problems and deficiencies in dose-assessment practices, 2) to recommend improved methods for caiculating doses to internal organs and tissues, 3) to recommend uniform methods for compliance with DOE orders, federal regulations, and international scientific guidance for internal dose assessment, 4) to evaluate the accuracy and precision of bioassay laboratory measurements and the appropriateness of draft ANSi Standard N13.30. Performance Criteria for Radiobioassay, 5) to assist $D O E$ in the establishment of a bioassay laboratory accreditation program, and 6) to develop improved analytical techniques for in vitro and in vivo bioassay measurements.

As indicated by the scope of the Health Physics Outlay Program projects, the major emphasis at PNL continues to be the development of operational health physics criteria, instruments, and methods to ensure that radiation exposure to occupational personnel and to people in the environs of nuclear facilities is maintained as low as reasonably achievable. Particular emprasis has been placed on improving basic personnel radiation exposure measurement and recording proçrams.

In addition to the Health Physics Outlay Program projects, FNL staff provide technical assistance to DOE under the Environment, Safety, and Health Technical Support Program, which is concerned with facility safety, response to congressional committee inquiries, and the development of safety policy and standards. 


\title{
Personnel Neutron Dosimeter Evaluation and Upgrade
}

\author{
Project Managers: L. G. Faust and C. M. Stroud
}

This project is a continuing effort whose primary objective is to develop improved personnel neutron dosimeters and instrument systems. No single dosimeter presently available adequately measures neutron dose equivalent throughout the energy range of occupational exposures and only Bonner spheres were previously available with which to measure neutron spectra. This project focuses on the problems that affect the field determination of personnel neutron dose equivalent and compliance with applicable U.S. Department of Energy (DOE) orders and regulations. The project includes interfacing with regulatory and other federal agencies involved in neutron dosimetry, conducting research leading to the standardization of equipment and procedures for dosimetry systems, developing spectral measurement capabilities, and transferring new technology to industry and other organizations and agencies for implementation in the field.

During fiscal year (FY) 1988, research and development and other project activities included the following principal areas: 1) combination thermoluminescent dosimeter/track-etch dosimeter (TLD/TED) development and implementation; 2) field neutron spectrometer development; 3) total effective dose equivalent system review; 4) optically stimulated luminescent (OSL) dosimetry 5) superheated drop detectors; 6) optical track detectors for neutron dosimetry; 7) neutron depth-dose characterization; 8) a personnel neutron dosimeter assessment manual publication; and 9) accelerator health physics. Milestones have been met on most of the subtasks in these areas, which include efforts by subcontractors (universities, private companies, and DOE laboratories) in addition to efforts by Pacific Northwest Laboratory (PNL) staff. Progress made in these areas during FY 1988 is discussed in the following sections.

\section{Combination Thermoluminescent Dosimeter/ Track-Etch Dosimeter}

M. A. Parkhurst, D. E. Hankins (LLNL), J. F. Johnson, and S. J. Huang (UCONN)

Thermoluminescent dosimeters are effective for thermal neutron measurement, but do not have adequate sensitivity to fast neutrons to be used alone for all personnel dosimetry. Therefore, DOE sponsored the development of dosimeter-grade TEDs and the combination TLD/TED. Research and development efforts performed jointly by Lawrence Livermore National Laboratory (LLNL), the University of Connecticut (UCONN), and PNL continued through FY 1988.

At LLNL, staff continued development of the image analyzer system, software, and procedures that could be directly implemented by the users. A lower limit of neutron detection was determined to be approximately $5 \mathrm{mrem}$ using LLNL's procedures. The LLNL staff found that track size distribution was a means of separating neutron tracks from background tracks.

At UCONN, a boron-loaded radiator for CR-39 TEDs was developed to detect energies in the thermal to $500-\mathrm{keV}$ range. The sensitivity was increased by a factor of 20 for the energy range of 30 - to $60-\mathrm{keV}$ and by a factor of 2 for $120 \mathrm{-keV}$ neutrons, and by $25 \%$ for $500-\mathrm{keV}$ neutrons.

At PNL, the track size distribution resulting from exposures of multiple neutron sources of different discrete energies was examined. It was concluded that those track size distributions are additive, i.e., included in a single source of the same energy range. Although it is difficult to derive the incident neutron energy spectra from track size distributions, research to relate the data to energy distribution continues.

A working group meeting was held in FY 1988 to present the current data and progress to date on the combination TLD/TED and field neutron spectrometer to the DOE contractors that have their own neutron dosimetry programs. The state of the art in TED detectors, their processing, readout, and interpretation were presented by PNL and LLNL. Field experiences by the laboratories that had initiated implementation of the combination TLD/TED were also discussed. 


\section{Portable Field Neutron Spectrometer}

L. W. Brackenbush, S. D. Miller, W. D. Reece, and J. H. Thorngate (LLNL)

The PNL field neutron spectrometer (see Figure 1) was developed to fulfill the requirement for a portable, easy-to-use spectrometer for use by minimally trained personnel to make energy spectrum measurements and determine quality factor and dose equivalents in the workplace. The development and construction of a prototype was completed in FY 1988. The prototype consists of a detector module with built-in electronics and an analysis module with an IBM PC-compatible computer to control the acquisition and analysis of data. The detectors are a ${ }^{3} \mathrm{He}$ proportional counter to measure the neutron energy spectrum between $50 \mathrm{keV}$ and $5 \mathrm{MeV}$ and a tissueequivalent proportional counter (TEPC) to measure absorbed dose and to estimate the quality factor for neutrons with energies from thermal to $20 \mathrm{MeV}$. The prototype was thoroughly tested in the field and modifications were made to overcome the problems encountered. At LLNL, circuitry was developed for use with the NE-213 neutron detector that will be incorporated in the coming year(s).

\section{Total Effective Dose Equivalent System}

\author{
J. E. Tanner, L. W. Brackenbush, W. D. Reece, \\ and R. I. Scherpelz
}

The Environmental Protection Agency's (EPA's) "Radiation Protection Guidance to Federal Agencies for Occupational Exposure" (52 FR 2822-34) was approved by the President in January 1987, requiring the determination of effective dose equivalent; however, it gives no practical methodology for field implementation of effective dose equivalent. A feasibility study in FY 1987 showed that effective dose equivalent can be significantly less than the dose equivalent evaluated at the surface of the body.

In FY 1988, two DOE peer reviews were made of effective dose equivalent requirements and seven subtasks were identified: 1) Transport Codes, 2) Utility Codes, 3) Standard Phantom, 4) Relationship to DOE Laboratory Accreditation Program (DOELAP) and Internal Dosimetry, 5) Impact on Field Dosimetry, 6) Dosimetry System Criteria, and 7) Effective Dose Equivalent Criteria for External Exposures. The neutron transport calculations were completed for nine neutron energies for the female (in addition to the male, previously

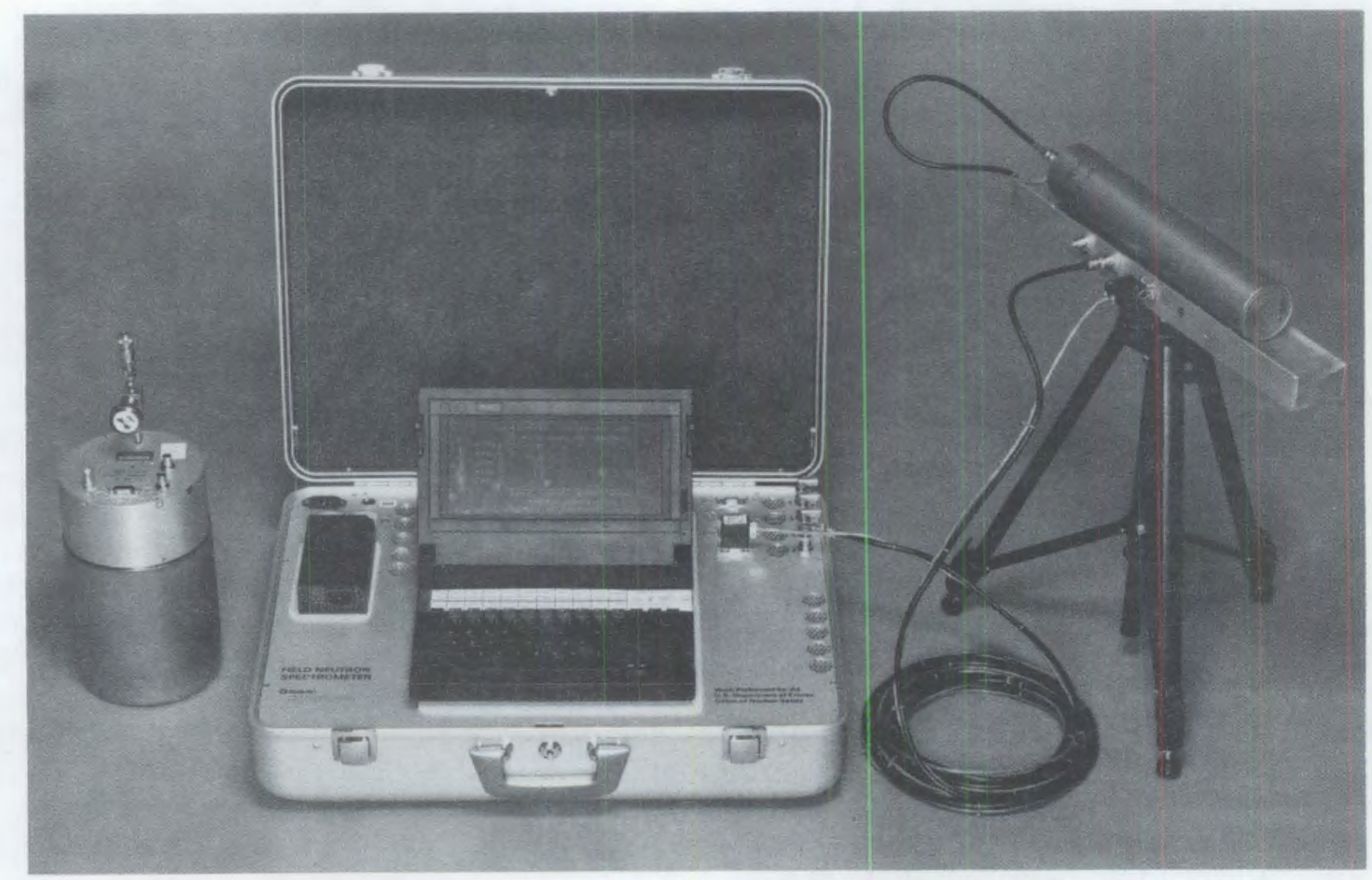

FIGURE 1. PNL Field Neutron Spectrometer 
completed) phantom (see Figure 2) in the anterior-posterior $(\mathrm{AP})$, posterior-anterior (PA), and lateral (LAT) parallel-beam geometries. A suitable source term to model an isotropic (ISO) field geometry was determined based on a series of test runs. Calculations for both male and female phantoms were initiated. The post-processing code was updated to include the quality factors for heavy-particle dose in tissue from first interactions of monoenergetic neutrons.

\section{Optically Stimulated Luminescent Dosimetry}

S. D. Miller

The shortcomings of TLDs and TEDs (angular dependency, inability to respond to the entire neutron energy range found in the workplace, and time-consuming processing for TEDs) have led to continued development of OSL dosimetry. In FY 1987, OSL techniques using $\mathrm{CaF}_{2}: \mathrm{Mn}$ crystals were shown to be sensitive to $1 \mathrm{mR}$ of gamma exposure when supercooled readout was used and to $100 \mathrm{mR}$ of gamma exposure when room temperature readout was used. The phosphors were shown to be stable even at elevated temperatures.

In FY 1988, an excimer laser and a dye laser were installed in the OSL laboratory and a firstgeneration prototype OSL reader was constructed. A patent was filed on the cooled OSL readout techniques (see Figure 3).
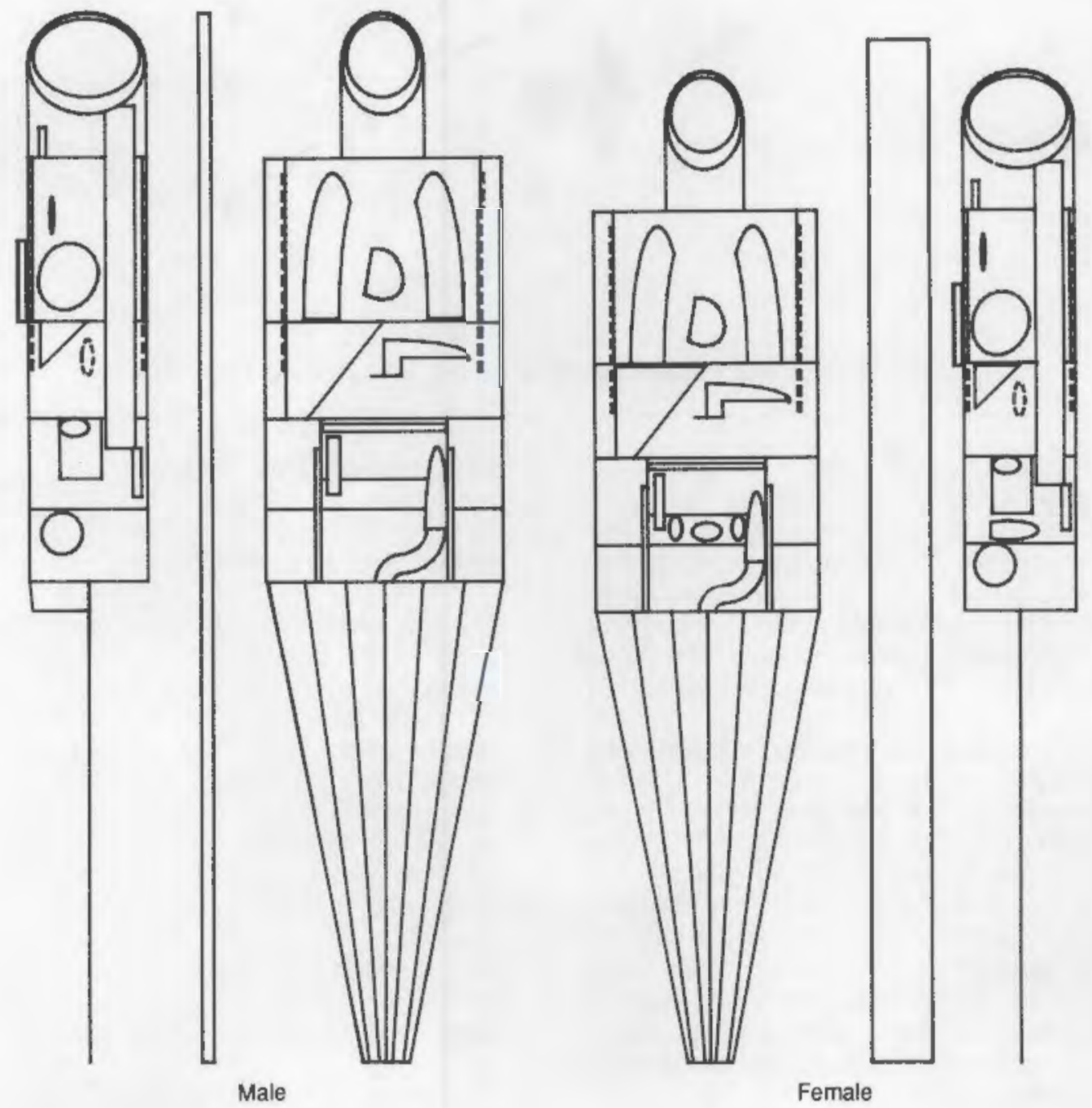

FIGURE 2. Male and Female MIRD Phantoms 
(1) Irradiated CaF2: Mn Crystal (100 mR 137Cs)

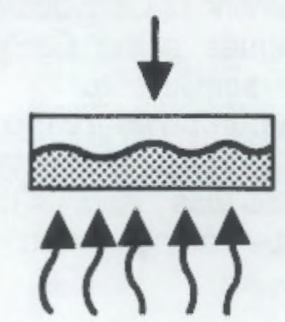

(2) Deep UV Stimulation
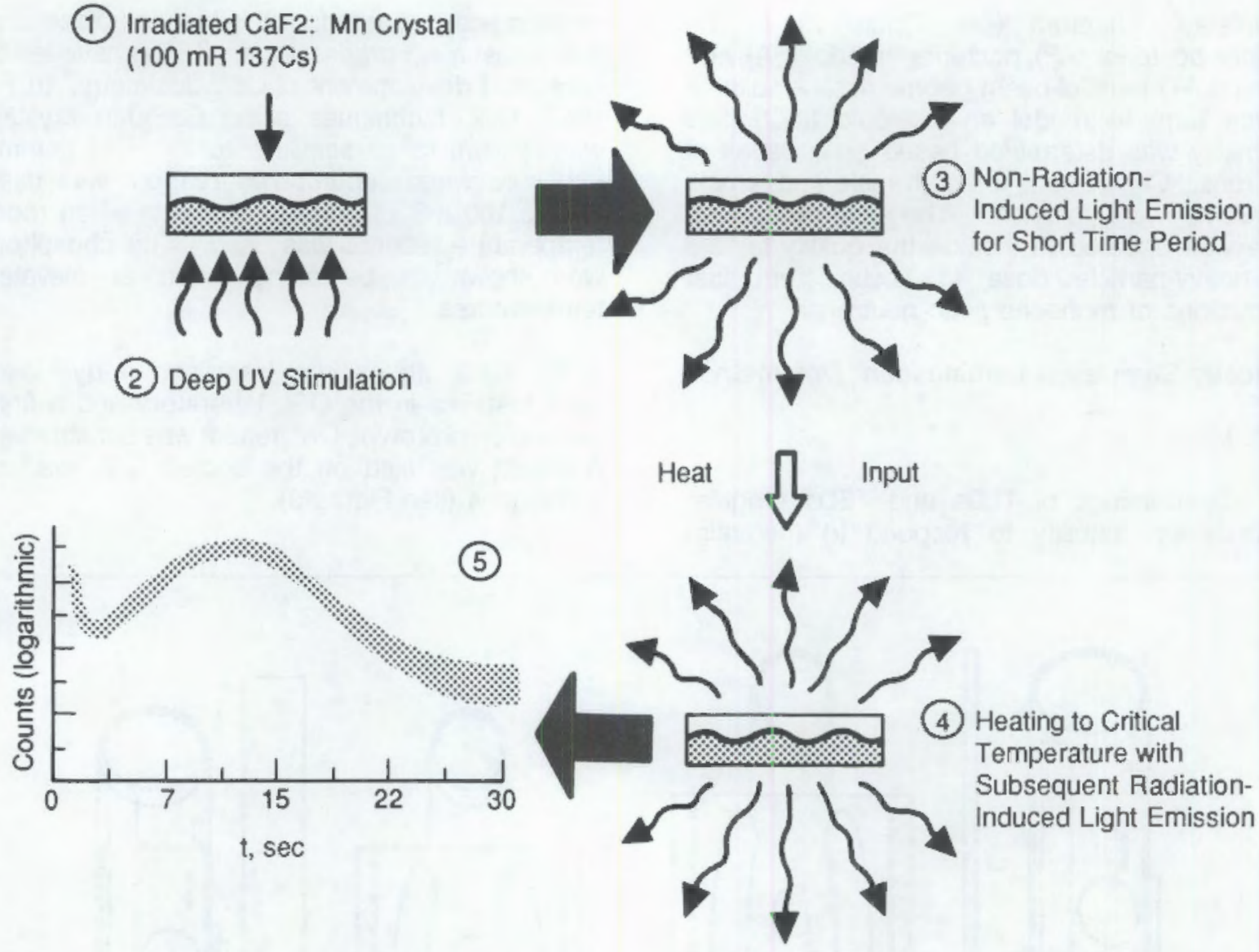

FGURE 3. Step-By-Step Cooled Optically Stimulated Luminescent Readout Procedure

During the further development of OSL techniques, it was found that $\mathrm{CaF}_{2}: \mathrm{Mn}$ could be annealed at room temperature using $325 \mathrm{~nm}$ light making it possible to anneal them within their plastic enclosures for neutron dosimetry. However, plastic was found to exhibit a long-time constant light emission when cooled and exposed to ultraviolet light. This problem must be solved.

In trying to resolve the phosphorescence difficulties, lithium fluoride was used and found to emit an orange and green luminescence when exposed to $442 \mathrm{~nm}$ blue light. Blue light causes less phosphorescence and LiF luminescence is measured at a wavelength where the phosphorescence is minimal. Lithium fluoride has the additional advantages of being more tissue equivalent and providing extremely fast readout. All of the OSL techniques have a great deal of promise for personnel and environmental dosimetry applications.

\section{Superheated Drop Detector}

R. E. Apfel (Apfel Enterprises), D. R. Sisk, C. M. Stroud, and K. L. Swinth

The superheated drop detector (SDD) has the potential for being an active neutron dosimeter that is insensitive to gamma radiation and capable of measuring neutron exposure from a few millirem to several rem. Apfel Enterprises designed and produced a prototype SDD in which superheated droplets of Freon or isobutane are suspended in a high-viscosity liquid. The droplets vaporize when struck by a neutron or proton. The sound of the "exploding" droplet is recorded and displayed digitally. The first prototype SDD had numerous problems, e.g., overflow of the vials when exposed to moderate radiation, temperature dependence, shock dependence, and

(2) Freon is a registered trademark of E.I. du Pont de Nemours and Company, Wilmington, Delaware. 
energy dependence. Apfel redesigned the SDD and produced a second prototype to improve or eliminate the difficulties of the first prototype. This second prototype may be evaluated by PNL during FY 1989. While these devices have some use in personnel dosimetry, any large-scale use will be limited unless most, if not alt, of the above problems are eliminated.

\section{Optical Track Detector for Neutron Dosimetry}

J. E. Turner (ORNL), L. W. Brackenbush, and C. M. Stroud

Oak Ridge National Laboratory (ORNL) initiated efforts to build an optical track detector to be used as an area monitor for directly determining neutron dose and linear energy transfer (LET) distributions by optically measuring individual charged-particle tracks in an ionization chamber. Algorithms will be developed to relate the track data to the neutron energy spectrum.

When a charged particle enters a chamber, it efectronically excites the gas molecules, which emit light. This optical radiation is used to trigger a high-voltage, damped radiofrequency generator, which is applied across the electrodes of the chamber. The electrons in the particle track excite and ionize the surrounding gas. The light emitted by the gas molecules is imaged simultaneously by two cameras scanning across two perpendicular planes. The images are stored and analyzed in a computer for three-dimensional reconstruction of the track and direct relationship to dose and LET distributions.

During FY 1988, ORNL designed an ionization chamber with quartz cylindrical walls for optical transmission and purchased a proton-counting system, a pulsed radiofrequency voltage supply, and cameras. They investigated pulsed voltage sources, but found that the pulses were shorter than required. Modeling was also performed to determine the expected light output and track resolution, which in turn assists in the final design of the prototype instrument.

\section{Neutron Depth-Dose Characterization}

\section{R. I. Scherpelz}

The neutron depth-dose characterization report was written and entered into the PNL editing and clearance process. It will be published during the first quarter of FY 1989. This report describes calculations and experiments that determined neutron depth-dose profiles in a cylindrical tissueequivalent phantom. The comparison of the calculations and experiments showed good agreement and both techniques can be applied to the determination of doses to internal organs resulting from external neutron radiations.

\section{Personnel Meutron Dosimetry Assessment}

D. E. Hadlock, L. W. Brackenbush, L. G. Faust, M. A. Parkhurst, and C. M. Stroud

Personnel Neutron Dose Assessment Upgrade, Volume 1: Personnel Neutron Dosimetry Assessment (Hadlock et al. 1988) was completed and published. It provides guidance on the characteristics, use, and calibration of personnel neutron dosimeters with emphasis on new dosimetry development. It is applicable to neutrons ranging from thermal to less than $20 \mathrm{MeV}$. It provides background for general neutron dosimetry and relevant federal regulations and other standards. It also compares available neutron dosimeters and instruments.

\section{Accelerator Health Physics}

R. C. McCall (SLAC), L. M. Coulson (Fermi), H. J. Moe (ANL), and C. M. Stroud

Stanford Linear Accelerator (SLAC) staff developed and published a manual of good practices for health physics programs at DOE accelerator facilities. The manual presents guidance to be used in the development and conduct of radiation protection programs at DOE accelerator facilities. It provides greater emphasis on the unique characteristics from the radiation safety viewpoint of the various accelerators and less emphasis on those radiation safety aspects that are common to all accelerators.

Fermilab was designated as the lead laboratory for accelerator health physics and worked toward developing a report characterizing the health physics problems at accelerators, developing a list of health physics research requirements at accelerators, and establishing a means of communicating among DOE accelerator facilities.

Argonne National Laboratory is developing a systematic methodology for the assay of induced radioactivity in accelerator components and is preparing a report covering this subject. 


\section{References}

52 FR 2822-2834. January 27, 1987. U.S. Environmental Protection Agency, "Radiation Protection Guidance to Federal Agencies for Occupational Exposure; Approval of the Environmental Protection Agency Recommendations by the President." Federal Register.
Hadlock, D. E., L. W. Brackenbush, L. G. Faust, M. A. Parkhurst, and C. M. Stroud. 1988. Personnel Neutron Dosimetry Assessment. PNL-6620 Vol. 1, Pacific Northwest Laboratory, Richland, Washinglon. 


\title{
Beta Measurement Evaluation and Upgrade
}

\author{
Project Managers: L. G. Faust and K. L. Swinth
}

The Beta Measurement Evaluation and Upgrade Project is designed to provide continuing identification and resolution of significant problems that affect field measurement of beta dose and to ensure that DOE facilities can comply with applicable standards. The ob]ective of this project is to investigate and upgrade beta radiation measurements by developing improved personnel beta dosimeters and instruments used in U.S. Department of Energy (DOE) facilities.

The work performed during fiscal year (FY) 1988 can be classified into four major areas: 1) dosimeter development, 2) instrument development, 3) beta calibrations, and 4) theoretical considerations. Contributors to the total effort included universities, private companies, and other DOE laboratories in addition to the Pacific Northwest Laboratory (PNL) staff. Progress made in these four areas during FY 1988 is discussed in the following sections.

\section{Beta Dosimeter Development}

S. D. Miller, S. E. Merwin, J. S. Durharn, and K. L. Swinth

The objectives of this task are to identify and develop new and innovative beta dosimeters for assessing beta dose and for estimating beta spectra. Four types of dosimetry being further developed, tested, and evaluated are discussed in the following subsections.

Thermoluminescent Dosimetry. Personnel dosimetry that uses thin thermoluminescent chip technology can achieve an acceptable accuracy for determining shallow $\left(7 \mathrm{mg} / \mathrm{cm}^{2}\right)$ dose from radiation fields with mixed energies and of mixed radiation types. This was shown during earlier laboratory evaluation of the thin (approximately $17 \mathrm{mg} / \mathrm{cm}^{2}$ ) LiF chip backed by graphite, which was developed by Kansas State University (KSU) under subcontract to PNL. In order to evaluate this chip in an automated dosimetry system, a "KSU" chip was inserted into the "open" position of several personmel dosimeters and the dosimeters were irradiated using photon and beta sources specified by the DOE Laboratory Accreditation Program (DOELAP). The responses of both the thin and thick thermoluminescent dosimeters (TLDs) were analyzed using a non-linear leastsquares technique to determine the optimum shallow-dose algorithm. That algorithm was then used to evaluate the shallow-dose performance of dosimeters irradiated in mixed radiation fields, which included mixlure categories of ${ }^{90} \mathrm{Sr} /{ }^{127} \mathrm{Cs}$ and ${ }^{137} \mathrm{Cs} / 16-\mathrm{keV}$ (k-fluorescence) $\mathrm{x}$ rays. The results indicated that the dosimeters incorporating the thin "KSU" chip would pass the DOELAP shallow beta/photon personnel exposure categories (including the ${ }^{200} \mathrm{Tl}$ category) without special modification to the algorithm and without the use of chip ratios. The results also indicated that, as tested, the thin chip was not useful in determining the deep dose.

Laser-Thermoluminescent Dosimetry. The concept of using an infrared laser to provide the necessary heating for readout of TLDs was evaluated by testing the response of five different TLD designs to laser heating. The TLDs were irradiated by four beta sources and one gamma source and the response of the dosimeters was evaluated based on accuracy, reproducibility, lower limit of detectability, and energy response. The results showed that the use of the laserheating concept is superior to conventional techniques when used with a thin TLD design.

The advantages inherent in the laser-TLD concept are its ability to obtain a signal that is indicative of the beta dose in mixed beta-gamma fields and its rapid readout of dosimeters. In practice, the total time to read out a TLD and anneal it in the laser-TLD reader is 20 seconds, including handling time. The typical readout time for a conductive heating system is about 30 seconds for dose readout and over 2 hours for annealing.

A major physical problem in using a laser-TLD reader occurs when the thermoluminescent material is transparent to infrared (IR) radiation and a substrate must be used, which acts as the primary IR absorber and heat source. When a substrate is used behind the thermoluminescent material, the energy absorbed next to the substrate is no longer indicative of the beta dose unless the TLD is extremely thin. A more serious problem occurs when a binder must be used to 
attach the thermoluminescent material to the substrate. Most binders or glues are highly absorbing in the IR region. If the substrate does not rapidly conduct heat away from a strongly absorbing binder, the binder will heat up to its melting point and may destroy the TLD. For beta dosimetry, a thin TLD on a substrate with a low thermal mass was found to avoid the pitfalls inherent in the use of an IR laser-heating source.

For the laser-TLD evaluation of thin TLDs, 18 dosimeters containing $3 \mathrm{CaSO}_{4}$ :Dy TLDs, 2 LiF (TLD 700) TLDs, and $2 \mathrm{MgB}_{4} \mathrm{O}_{7}$ :Dy TLDs were irradiated and read out. The thickness of the $\mathrm{CaSO}_{4}:$ Dy TLD, TLD 700, and $\mathrm{MgB}_{4} \mathrm{O}_{7}:$ Dy TLD was $9.6 \mathrm{mg} / \mathrm{cm}^{2}, 85 \mathrm{mg} / \mathrm{cm}^{2}$, and $7.8 \mathrm{mg} / \mathrm{cm}^{2}$, respectively. All were mounted on a Kapton backing that was chosen for its low thermal mass. The badges were irradiated by four different sources $\left({ }^{80} \mathrm{Sr} /{ }^{90} \mathrm{Y},{ }^{147} \mathrm{Pm},{ }^{85} \mathrm{Kr}\right.$, and depleted uranium) to doses that ranged from 10 to $500 \mathrm{mrad}$. The sensitivity correction factor was obtained for a 1-rad dose from a ${ }^{60} \mathrm{Co}$ gamma source and applied to the readings to correct for variations in element sensitivity.

The measured response of the three thin TLDs is presented in Table 1. The poor response of the tissue-equivalent TLD-700 dosimeters is easily explained based on the thickness of the material. The TLD-700 chips were much thicker than the range of low-energy beta particles but thin enough to be uniformly irradiated by the gamma calibration source. The amount of energy deposited within the TLD by beta particles will therefore be smaller when averaged throughout the entire volume of the TLD than the amount of energy deposited by a gamma source. Thus, the TLD-700 dosimeters show an increasing response with increasing beta energy, as well as a lower response than the $\mathrm{CaSO}_{4}: \mathrm{Dy}$ TLDs at lower energies

TABLE 1. Response of the Thin TLDs Compared to ${ }^{50} \mathrm{Co}$

\begin{tabular}{llll}
$\begin{array}{c}\text { Mean Beta } \\
\begin{array}{c}\text { Energy, } \\
\text { MeV }\end{array}\end{array}$ & \multicolumn{4}{c}{ Response for Dosimeters } \\
\cline { 2 - 3 } 0.06 & $\begin{array}{ccc}\text { CaSO } \\
0.01 \pm 0.03\end{array}$ & $0.14 \pm 0.01$ & $0.85 \pm 0.03$ \\
0.23 & $1.01 \pm 0.05$ & $0.66 \pm 0.59$ & $0.85 \pm 0.09$ \\
$0.8(\mathrm{DL})^{\{a j)}$ & $0.99 \pm 0.04$ & $0.78 \pm 0.16$ & $0.88 \pm 0.04$ \\
0.8 & $0.97 \pm 0.07$ & $0.87 \pm 0.14$ & $0.87 \pm 0.11$ \\
Overall & $1.00 \pm 0.05$ & $0.65 \pm 0.30$ & $0.86 \pm 0.06$
\end{tabular}

(a) DU = depleted uranium.
The difference in response between the $\mathrm{CaSO}_{4}: \mathrm{Dy}$ and the $\mathrm{MgB}_{4} \mathrm{O}_{7}$ :Dy dosimeters is difficult to understand. Because both types of dosimeters were calibrated in the same manner and both of the TLDs are thin, the response of the two TLDs was expected to be similar. It is possible that the heating cycle for the $\mathrm{MgB}_{4} \mathrm{O}_{7}$ :Dy TLDs was not optimized as well as that for the $\mathrm{CaSO}_{4}$ :Dy TLDs. This difference in response will be investigated when testing is resumed. From the data collected in the laser-TLD evaluation, the minimum level of detection for the $\mathrm{CaSO}_{4}$ :Dy TLDs was found to be approximately $1 \mathrm{mrad}$.

Two additional TLD designs were evaluated using the laser-TLD reader. The TLD developed by KSU (using a thin $\left[17 \mathrm{mg} / \mathrm{cm}^{2}\right]$ LiF TLD bonded to a thick graphite backing) was tested for its applicability in a laser-TLD reader. The other TLD that was evaluated was designed by VINTEN Corporation. 17 the VINTEN design small LiF crystals are distributed throughout a graphite matrix. Both the KSU and VINTEN dosimeters are designed for sturdiness in handing, and both are intended for use with conventional readers. The TLDs were irradiated by gamma radiation to levels of 1,5 , and $10 \mathrm{rad}$. It was found that the binder on the $\mathrm{KSU}$ dosimeter was strongly absorbing in the IR range and consequently melted during readout. Because the metting destroyed the dosimeter, it was determined that the KSU dosimeter is not a good candidate for laser readout. The lower limit of detection for the VINTEN dosimeter was just below $1 \mathrm{rad}$, too restrictive for use as a personnel dosimeter with the laser-TLD reader.

Based on the studies conducted in this evaluation (with the exception of the KSU case discussed previously), it is apparent the laser-TLD reader concept is fast, accurate, reproducible, and highly sensitive when used with a thin TLD design. The results cobtained by using IR laser heating of thin TLDs can be expected to be superior to the results obtained by conventional readout methods. Laser heating of thin TLDs can provide the ability to measiure very low doses, even in a highbackground environment. Of the three thin TLD designs evaluated, $\mathrm{CaSO}_{4}$ :Dy appears to be the best, followed closely by $\mathrm{MgB}_{4} \mathrm{O}, \mathrm{Dy}$. Both of these th $n$ TLDs have a very flat energy response and both have the potential to measure doses on the order of $1 \mathrm{mrad}$. The thickness of the LiF TLDs tested does not appear to be conducive to accurate measurement of beta dose.

Exoelectron Dosimetry. in November, a letter report $\epsilon$ ntitled "Preliminary Investigation of the 
Suitability of Exoglectron Dosimeters for Personnel Beta Dosimetry" was prepared for DOE. The report described the results of initial testing of the dosimeters, including the results of thermal fading, optical fading, normal fading, gamma energy dependence, beta energy dependence, dose response, reproducibility, and sensitivity. From the favorable results of these tests, it is concluded that exoelectron dosimeters may have potential for use as personnel beta dosimeters.

During FY 1988, 210 new exoelectron dosimeters were received from the German supplier for testing. Testing indicated that the first 10 dosimeters were approximately $10 \%$ as sensitive as the previous 53 dosimeters purchased in $\mathrm{FY} 1987$. The remaining 200 dosimeters were approximately $60 \%$ as sensitive as the initial 53 dosimeters; however, the element correction factors in this batch of 200 varied by as much as a factor of 4 . It appears that the production of these dosineters has not yet been perfected, although even the least sensitive dosimeters produced can detect a dose of $1 \mathrm{mrem}$. A new reader was ordered with a multianode counter. This will improve the dynamic range and the precision of the readout.

Efforts during FY 1988 focused on the development of a personnel dosimeter that can meet DOELAP criteria for both beta and photon radjation. The first dosimeter design contained only two elements, one to measure the shallow dose at a depth of $7 \mathrm{mg} / \mathrm{cm}^{2}$ and one to measure the deep dose at a depth of $1000 \mathrm{mg} / \mathrm{cm}^{2}$. Although this dosimeter easily met DOELAP criteria for both beta and gamma radiation, it underresponded to low-energy $x$ rays. As a result, a third element was added to the dosimeter. This element was similar to the deep-dose element except for a thin layer of aluminum between the dosimeter and the $1000 \mathrm{mg} / \mathrm{cm}^{2}$ Teflon cover. The presence of the aluminum causes an overresponse to low-energy photons, which allows for the determination of the low-energy photon component of the incident radiation and a correction of the response of the shallow- and deep-dose elements. Testing of several designs of this third element resulted in an exoelectron dosimeter that can meet DOELAP criteria for all beta energies and other photons, with a maximum $23 \%$ error for the worst-case mixlure. Testing of new designs is continuing to further improve measurement accuracy.

\footnotetext{
(5) Teflon is a registered trademark of E. I. du Pont de
} Nemours and Company. Wilnington, Delaware.
The three-element dosimeters described above were used for measurements at a production facility. In general, the dosimeters performed well, although the precision was not as good as expected. Field evaluations will continue. It was also determined that exoelectron dosimeters are excellent devices for measuring dose rates from so-called "hot particles." The dosimeters are ideal for these measurements because of their flat beta response and extremely thin sensitive layer, which makes it possibie to determine the dose at a depth of $7 \mathrm{mg} / \mathrm{cm}^{2}$ using a $7-\mathrm{mg} / \mathrm{cm}^{2}$ cover. Only occasional "hot particles" are found in DOE facilities, but implementation of highly sensitive contamination measurement techniques at licensed facilities has shown that these highly active particles are a larger problem than generally expected.

Optically Stimulated Luminescence Dosimetry. Work continues on a study of the optically stimulated luminescence (OSL) of materials for applications in dosimetry. Light offers the advantage of interrogating a dosimeter without the harmful effects of the high-temperature characteristic of thermoluminescent dosimetry. This will reduce the time for analysis of the dosimeters compared with current thermoluminescent systems. Because the OSL systems do not require the high temperatures encountered in conventional thermoluminescent dosimetry, thin layers can be made of the OSL materials in a plastic binder. The thin layer will provide a flat response to a wide range of beta energies. In tests performed with plastics to determine their suitability as binders, phosphorescence was observed, which interferes with dosimeter readout. Changes in plastic formulation were made and tested in order to find a suitable method to avoid this interference.

A new readout process was developed called "cooled optically stimulated luminescence," which provides ultrasensitivity to the complete system. A patent application has been filed and is currently under consideration. A paper describing this process was prepared and submitted to Radiation Protection Dosimetry. A laser lab was designed and completed this fiscal year, which will provide the tools for developing the readout technologies and evaluating future OSL applications. The laboratory has advanced laser systems, a computing station, and optical hardware. Three materials $\left.(\mathrm{NaCl}[\mathrm{Ag}]), \mathrm{LiF}_{1} \mathrm{CaF}_{2}[\mathrm{Mn}]\right)$ have been identified, tested, and found to be strong candidates for an OSL beta dosimeter. 


\section{Beta Instrument Development}

\section{R. Sisk and K. L. Swinth}

This task is dedicated to the development of instrumentation to enable the accurate measurement of radiations, both penetrating and nonpenetrating.

Analysis of the source geometry dependence of survey meters continued. Measurements were performed with the scanning system using additional thin $(1-\mathrm{cm})$ ionization chambers of various diameters. Correction factors determined for the thin chambers are relatively small and typically decrease with decreasing chamber diameter. These results reflect the reduced source geometry dependence of small thin detectors, which can be irradiated more uniformly. Additional measurement results and analyses have been incorporated into the dratt report on the source geometry dependence studies.

Information on ion chamber response calculations was presented at the $33 \mathrm{rd}$ Annual Meeting of the Health Physics Society in Boston, Massachuselts, in July 1988 (Sisk and Swinth 1988). A paper will be submilted for publication describing the technique and presenting an analysis. The calculational technique provides a relatively simple and instructional means for evaluating survey meters. Prototype survey meter chamber designs can now be easily analyzed by computer, which facilitates development of techniques leading to the reduction of geometry dependence.

Information from the study has been used to develop specifications for a prototype beta survey instrument. The instrument will employ a thin $(1.5 \mathrm{~cm})$ chamber with low-density $\left(7-\mathrm{mg} / \mathrm{cm}^{2}\right)$ walis and window. The thin chamber volume will reduce the instrument's geometric sensitivity. In addition, the instrument will be microprocessorbased and be capable of storing and retrieving geometry correction factors from its own memory and applying them to the readings. The proper correction factor will be selected based on geometric information supplied by the operator via keypad. This will allow the operator to quickly, easily, and accurately correct instrument readings in the field.

Optimization, fine funing, and field testing of the beta/gamma field spectrometer continues. The spectrometer uses a coincidence techrique employing two detectors to separate the beta and gamma components from a mixed radiation field.
The instrument consists of a gas-How proportional counter attached to the front of a plastic scintillator detector. Beta particles entering the system generate a signal as they pass through the proportional counter and deposit their remaining energy in the scintillator. Conversely, the low thickness density of the proportional counter prevents gamma detection. Gamma radiation is detected solely by interactions in the plastic scintillator. Gating circuitry selectively routes a beta or gamma scintillator pulse to a muttichannel analyzer that collects the energy pulses to produce a spectrum. A computer is used to calculate dose rates from spectra coliected using the spectrometer system.

Field measurements have been made with the system and it has demonstrated good performance. Outdoor measurements initiated in January 1988 are continuing because the cold ambient temperature seemed to distort the spectra. Measure nents performed in the laboratory on microscopic particles of activated reactor fuel or activated metal ("hot particles") consistently produced good results. The system was also used at a DOE production facility to collect beta spectra.

Recent improvements in the detector system have resulted in a tenfold improvement in efficiency in the laboratory. In addition, a new multichannel analyzer (MCA) has been purchased, which incorporates gating circuitry and high-voltage power supplies. Sofware can easily be instailed in this MCA to calculate dose rates from the spectra. This will significantly reduce system volume and increase portability. In the future, emphasis will be placed on reducing noise in the proportional counter circuitry, miniaturization of the system, increasing portability, and decreasing gamma sensitivity.

Presently, a new beta spectrometer system, which will have! improved efficiency and noise characiteristics, is being purchased to PNL specifications.

\section{Theoretical Considerations}

\section{K. L. Swinth and W. D. Reece}

The purpose of this task is to conduct basic studies that alfect beta dosimetry and to develop methods of calculating energy deposition from beta radiation.

Calculational studies are under way at KSU to study thie beta emission characteristics of the 
PTB $^{\text {(a) }}$ source set, to intercompare codes, and to study the responses of various TLD materials. The computer code EGS4 (three-dimensional coupled electro-photon transport) was placed into operation and test results for three-dimensional problems agreed well with those reported by Berger and Seltzer in NBS Report NBSIR 82-2451 (1982).

The Integrated TIGER Series (ITS) code was also installed on the KSU mainframe computer. This code package incorporates one-dimensional (TIGER), two-dimensional (CYLTRAN), and threedimensional (ACCEPT) codes for coupled electron and photon transport. Calculations were undertaken to intercompare the CYLTRAN and EGS4 codes, which identified an effort in the "user code" required to supplement the EGS4 code.

Work has been completed on the comparison of skin dose and TLD response for calcium-tivoride TLD devices under a previous contract. Work is in progress on the comparison of skin dose and TLD response for lithium-tetraborate TLD devices.

Calculations were made of the beta particles emilted from the PTB sources as a function of angle. Results are in the form of electron angular-energy spectra, namely the fractions of electrons emerging per unit energy per steradian, averaged over the polar-angle ranges 0 to $30^{\circ}$, 30 to $60^{\circ}$, and 60 to $90^{\circ}$ measured from a polar axis normal to the source window. Comparison with the isotropic spectra from a pure unencapsulated source shows that low-energy beta particles are absent due to the encapsulation. Attenuation becomes significant below about $50 \mathrm{keV}$ for ${ }^{147} \mathrm{Pm}, 200 \mathrm{keV}$ for ${ }^{204} \mathrm{Tl}$, and $500 \mathrm{keV}$ for ${ }^{80} \mathrm{Y} /{ }^{80} \mathrm{Sr}$. Also evident is an apparent backscatter effect for ${ }^{204} \mathrm{TI}$ and ${ }^{80} \mathrm{Sr} /{ }^{80} \mathrm{Y}$ sources. There are two goals: 1) examination of the effects of the beamflattening filters; and 2) determination of calibration factors relating TLD dose to skin dose.

A draft report on biological considerations for proper depth and methods for assessing dose to the skin was completed. Under uniform irradiation, the dose rate at $4 \mathrm{mg} / \mathrm{cm}^{2}$ versus $7 \mathrm{mg} / \mathrm{cm}^{2}$ increases by 15 to $20 \%$, but for point sources the dose rate is driven by geometry and increases by nearly a factor of 2 .

\section{References}

Berger, M. J., and S. M. Seltzer. 1982. Tables of Energy-Deposition Distributions in Water Phantoms Irradiated by Point-Monodirectional Electron Beams with Energies from 1 to $60 \mathrm{MeV}$, and Application to Broad Beams. NBSIR 82-2451, National Bureau of Standards, Washington, D.C.

Sisk, D. R., and K. L. Swinth. 1988. "Ion Chamber Response Calculations Based on Beta Radiation Simulations." Poster and paper presented at the 33rd Annual Meeting of the Health Physics Society, July 4-10, 1988, Boston, Massachusetts.

(a) PTB stands for Physikalish-Technische Bundesanstalt (Physical Technical Institute [West German equivalent of the Nationa! Bureau of Standards]). 



\title{
Health Physics Support and Assistance to the Department of Energy
}

\author{
Project Managers: J. M. Selby, J. G. Stephan, and J. B. Martin
}

This project focuses on identifying needed improvements in occupational radiation programs and measurement technologies and on analyzing the applicability and impact of standards, regulations, and engineering or administrative actions on the U.S. Department of Energy's (DOE's) occupational radiation protection programs. This is accomplished by means of special technical studies. Technical assistance is provided in developing guidelines for implementing standards and regulations and in conducting and preparing technical reports as requested by the sponsor. This assistance also includes transferring laboratory-developed techniques to the field by means of DOE-sponsored workshops. Project objectives are achieved using the capabilities and expertise of Pacific Northwest Laboratory (PNL), other DOE laboratories, universities, and private industry. Progress made during fiscal year (FY) 1988 on the Health Physics Support and Assistance (HPS\&A) tasks is discussed in the following sections.

\section{Neutron Quality Factor}

\section{G. Faust}

The International Commission on Radiological Protection (ICRP) and the National Council on Radiation Protection and Measurements (NCRP) have proposed changes to the quality factors, $Q$, associated with high linear energy transfer (LET) radiations; e.g., protons, neutrons, and alpha particles. Because of the absence of spectral data, the currently accepted values for $Q$ will essentially be doubled if average values are used. For neutrons, the average values would be 5 for thermal and 20 for fast neutrons. The DOE $A d$ Hoc Committee on Neutron Quality Factor reviewed a large amount of data that was used to support ICRP and NCRP recommendations and issued their own report, which supported the suggested changes. However, the report indicated that, in the case of neutrons, spectral data should be used wherever and whenever possible, rather than using an average value of 20 .

Subsequently, the Ad Hoc Committee report has undergone a peer review, which supported its findings. The Committee on Interagency Radiation Research and Policy Coordination (CIRPPC) has performed at least two reviews, both of which suggested no change in $\mathrm{Q}$. Neither CIRPPC report was, or is likely to be, released. Regardless of the CIRRPC review, the Ad HoC Committee members maintained their original conclusion; i.e., to double $O$ for fast neutrons if spectral data are available and, if not, to use an average $Q$ of 20 , comsistent with the statement of the 1985 Paris meeting of the ICRP (ICRP 1985) and NCRP Report 91 (NCRP 1987).

\section{ALARA Engineering}

\section{J. W. Baum (BNL)}

The ALARA (as low as reasonably achievable) Engineering Project was initiated by Brookhaven National Laboratory (BNL) during the second quarter of FY 1988 to provide DOE with radiation exposure oversight. A system was developed to link the BNL ALARA Center with the DOE RECON database. A customized search routine was developed to select those abstracts that are of particular interest to the DOE ALARA Engineering Project. Several hundred abstracts are being reviewed to determine if additional selectivity is required in the search process. Abstracts selected for the final bibliography will be processed using the special software and procedures described in the manual for the ALARA bibliography system.

A data-gathering trip was made to Los Alamos National Laboratory. A trip (separately funded) was aiso made to attend an Nuclear Energy Agency (NEA) tneeting where a similar center is being developed. The Third European Scientific Seminar on Radiation Protection Optimization held in Madrid, Spain, was also attended. Information from these two meetings will be valuable in the conduct of the DOE ALARA Engineering Project.

\section{Annual Radiation Exposure Report}

\section{S. E. Merwin}

The nineteenth annual report on "DOE Radiation Exposure for DOE and DOE Contractor Employees" for the year 1986 was prepared and provided 
to the sponsor for publication (Patridge and Merwin 1988). This report is one of a series of annual reports provided by DOE summarizing occupational radiation exposure received by $\mathrm{DOE}$ and DOE-contractor personnel. The report reffects data on a total of 94,040 DOE and DOEcontractor employees monitored for radiation exposure. Additionally, data on 63,463 monitored visitors are presented. Thirty-four charts and twenty-two tables are provided in the report indicating exposure trends for the years 1978 through 1986.

\section{Brazilian Cesium Irradiator Accident}

\section{R. J. Traub, J. M. Selby, and D. R. Fisher}

Assistance was provided in the assessment of the consequences of the Brazilian accident involving a cesium irradiator. A cesium therapy source was found by members of a Brazilian family and taken to their home. Subsequently, the source containment was breached and part of the contents was ingested by a young female and others in the family. An initial measurement of the activity inside the young female consisted of a survey meter reading taken at her anterior medial surface; the reading was $130 \mathrm{mrem} / \mathrm{h}$. To estimate the activity inside the individual a radiation shielding code was used. The computer code estimated the dose rate to a point in front of a mathematical model of the young female. Adjustment of the data supplied to the code allowed for an estimate of the activity taken into the body of the individual. The estimated ${ }^{137} \mathrm{Cs}$ content of the female ranged from 7 to $13 \mathrm{mCi}$ at the time of the reading. Several runs of the computer code indicated that the estimate of the ${ }^{13} \mathrm{Cs}$ content would vary dramatically depending on the assumed location of the survey meter and especially the distance between the female and the detector.

\section{Report on Missed Dose}

\section{R. J. Traub}

Effort was begun to summarize and document in a report the current status of internal and external dosimetry. The report will place particular emphasis on "missed dose." Missed dose is the radiation oose that individuals may have received but that was not recorded in their permanent occupational exposure histories. In the report, an attempt is made to identify the sources of missed dose, quantify the significamce of each source, and identify other problems that may affect the validity of the recorded dose.

The report divides missed dose into four major categories: 1) true missed dose, 2) unnoticed dose, 3) underrecorded dose, and 4) unreliable dose. One basis for this report is the results of intercomparison studies that have been performed by PNL and other laboratories. These include studies of bioassay measurements, health physics survey instruments, extremity dosimeters, and personnel (work badge) dosimeters. The participants in these studies have included most DOE facilities and several U.S. Nuclear Regulatory Commission (NRC) licensees. These intercomparison studies help to determine the bias, precision, and minimum detectable level for dosimetry systems under strictly defined laboratory conditions. Another basis for the report on missed dose is the radiation measurements that PNL has made in the workplace at both DOE and NRC-licensee facilities. These measurements have included measurements of beta, gamma, and neutron dose and spectra.

Work or this task was discontinued because of lack of available funding.

\section{Health Physics Manuals of Good Practice}

\section{J. M. Selby, L. G. Faust, and J. G. Stephan}

The objective of this project was to identify and develop health physics manuals of good practices to be used by the DOE facilities to enhance radiation practices in the workplace. Changes in technology, orders, standards, and regulations played at key role in the development process. Because of the value of these guidelines, the manuals received wide UC-41 distribution. The manuals were prepared by a working group of technical experts and were extensively reviewed within the DOE community. The DOE Expert Group on Internal Dosimetry participated in preparation of the plutonium and uranium manuals. Technicat experts from the following organizations participated in the preparation and/or review of the man Jals: DOE Office of Nuclear Safety, Oak Ridge National Laboratory, Savannah River Plant, Argonne National Laboratory, Rocky Flats Plani, PNL, Martin Marietta Energy Systems, Los Alamos National Laboratory, Brookhaven National Laboratory, EG\&G Idaho, Rockwell Hanford Operations; Lawrence Livermore National Laboratory, Westinghouse Icaho Nuclear Company, Science Applications International Corporation, Stanford Linear 
Accelerator Facility, and Sandia National Laboratories. The following manuals were completed and published during 1988:

- Health Physics Manual of Good Practices at DOE Uranium Facilities, EG\&G Idaho, lead organization (Rich et al. 1988)

- Health Physics Manual of Good Practices for the Prompt Detection of Airborne Plutonium in the Workplace, $\mathrm{PNL}$, lead organization (Mishima et al. 1988)

- Health Physics Manual of Good Practices for Reducing Radiation Exposure to Levels that are As Low As Reasonably Achievable (ALARA), PNL, lead organization (Munson et al. 1988)

- Health Physics Manual of Good Practices at DOE Plutonium Facilities, PNL, lead organization (Faust et al. 1988)

- Health Physics Manual of Good Practices for Accelerator Facilities, Stanford Linear Accelerator Facility, lead organization (McCall et al. 1988).

The Health Physics Manual of Good Practices for Radiation Protection Training (Westinghouse Idaho Nuclear Company, lead organization) and the Health Physics Manual of Good Practices for Radiation Safely Technician Training (Argonne National Laboratory, lead organization) have been completed and will be printed and distributed in early FY 1989.

The first draft of the Health Physics Manual of Good Practices for X-Ray Devices and Sources at DOE Facilities (PNL, lead organization) is being reviewed by the technical working group. This manual will be completed in FY 1989.

\section{Technical Evaluation of the Capability of Present Instrumentation to Meet the Require- ments of Draft ANSI Standard N42.17}

\author{
E. E. Hickey, K. L. Swinth, G. A. Stoetzel, D. R. \\ Sisk, and M. R. Tinker
}

The objectives of this task are: 1) to evaluate the applicability and practicality of the proposed American National Standards Institute (ANSI) Standards N42.17A, $B$, and $C$ regarding performance specification for health physics instrumentation; 2) to determine the degree of conformance to the proposed standards of selected, currently available commercial instruments, 3) to develop a formal test, evaluation protocol, and specific procedures; and 4) to lay the groundwork for establishing a permanent testing and certification laboratory.

The processor for the automated data-acquisition system was tested and found to operate satisfactorily. Two remote data-entry terminals were specified for the system and purchased. A paper, titled "Computer Controlled Testing and Calibration of Health Physics Instruments" (Swinth and Sisk 1987), was presented at the fall Institute of Electrical and Electronics Engineers, Inc., Nuclear Science Symposium. The paper discussed the value of automation in testing and calibration.

ANSI N42.17A was revised and sent to DOEHeadquarters (HQ) for distribution to the ANSI N42.1 committee for balloting. Work continued on the final documentation for Parts 1 and 2 reports on instrument testing against ANS $\mathrm{N} 42.17 \mathrm{~B}$ and $\mathrm{C}$. The reports are close to completion but still require peer review and editing.

Work continued on air-monitoring testing. The aerosol generator and associated equipment needed for deposition testing has been set up and tested. Solutions were made to generate 2-, 8-, and $10-\mu \mathrm{m}$ particles using fluorescein and isopropyl alcohol. Particles were generated, collected, and sized. However, the particles were much smaller than expected and it was determined that the solutions were too dilute. When a more concentrated solution was prepared, the fluorescein would not dissolve in the isopropyl alcohol. Particles in the appropriate size range are now being generated using uranin and methyl alcohol. Refining the procedure and troubleshooting the problems will continue as the air monitors are tested.

\section{Air Sampling and Monitoring}

E. E. Hickey, J. Mishima, J. M. Selby, and K. L. Swinth

The objective of this task is to develop techniques for measuring and interpreting levels of radioactive materials present within DOE facilities. Techniques for control of radioactive material in the air and calibration of systems will also be studied and improved.

The working group established for preparing guid ance for the prompt detection of plutonium in the workplace met September 30 to October 1, 1987 . 
at Rocky Fiats to review and coordinate the guidance document. Subsequently, a draft document was prepared and reviewed. A paper, partially based on this work, entitled "Airflow Patterns in Complex Workplaces," was presented at the winter American Nuclear Society (ANS) meeting in Los Angeles (Mishima et al. 1987). Another paper, entitled "New Developments in Continuous Monitoring of Airborne Activity," was presented at the same meeting (Swinth et al. 1987).

In January 1988, the Workplace Transuranic Aerosol Measurement System (WOTAMS), which was designed for prompt detection of airborne plutonium, was received from Lawrence Livermore National Laboratory (LLNL), which developed WOTAMS under subcontract to PNL. The system, which uses two detectors, represents a substantial improvement in detection capability. The detection capability is calculated to be less than 5 maximum permissible concentration hours (MPC-h) for the first detector and below $0.5 \mathrm{MPC}-\mathrm{h}$ for the second detector.

The WOTAMS unit, which was scheduled to be shipped to PNL at the end of FY 1987, was delayed because of software problems. During the first quarter of $F Y$ 1988, development continued on the computer code for the system and minor electronics and mechanical debugging was completed. Personnel from LLNL presented an operational review of the system at the end of January 1988. At that time it was discovered that the data link did not work. The new board needed to correct the problem with the data link for the WOTAMS air monitor was received from LLNL. The board has been installed and testing against draft ANSI N42.17B has begun.

The Rocky Flats air monitor, which consists of a filter media and detector, is being modified for production of large quantities of sampling heads and instruments. The estimated sensitivity of this system is between 1.5 to $2 \mathrm{MPC}-\mathrm{h}$. The air monitor detector/collector is currently under evaluation at Rocky Flats.

Work by Rocky Flats on the upgrade of their air monitor continued during the second quarter Testing of the air monitor revealed radio frequency problems that are currently being corrected. Further testing will be perlormed on the instrument during the next fiscal year.

A 2-hour short course on air sampling and air monitoring standards and methodology was prepared and presented as a continuing education topic at the annual Health Physics Society meeting in July 1988 (Selby, Mishima, and Swinth 1988).

\section{Evaluation and Upgrade of Extremity Dose Measurement at DOE Facilities}

\section{R. Harty and W. D. Reece}

The objective of this task is to evaluate and resolve problems associated with the use of extremity dosimetry at DOE facilities. During Fy 1988, the major emphasis of this subtask was to test the performance of extremity dosimeters in order to meet two goals: 1) to ensure that accurate results are obtained from extremity dosimeters irradiated in a calibration facility, and 2) to evaluate the response of DOE extremity dosimeters, as compared with criteria presented in the extremity dosimetry standard under development by the Health Physics Society Standards Committee (HPSSC).

The first round of irradiations of extremity dosimeters was compieted in late July for the performance-testing study of extremity dosimeters. The dosimeters were returned to the facilities. The facilities were asked to assess the dose on the dosimeters, knowing only which dosimeters were irraciated in accident dosimetry and neutron dosimetry categories 1,2 , and 6 . The facilities were not aware of which dosimeters were irradiated in all other irradiation categories, including photon, beta radiation, and radiation mixtures. After PNL receives the results, a list of the dosimeters that were irradiated in each of the categories will be sent to the facility. The facilities will then be asked to reassess the results based on the informaticn provided. Initial results have been received from four of the nine facilities participating in the study. In several of the categories, the laboratories experienced considerable difficulty in the initial assessment of doses.

Extremity dosimeters have been received for the second round of testing from seven of the nine facilities farticipating in this study. Although one of the facilities has indicated that their dosimeters will be arriving late, we will be able to include these dosimeters after their arrival. The other facility has indicated that they will be unable to participate in the second round of testing due to equipment complications. 
Technical Evaluation of National and International Occupational Radiation Exposure Recommendations, Standards, and Regulations

\section{J. M. Selby and J. G. Stephan}

The objective of this task is to provide a timely, technical evaluation of national and international occupational radiation exposure recommendations, standards, and regulations to determine their technical applicability, compatibility with DOE operations and orders, and their impact on DOE operations. As appropriate, technical expertise is drawn from other DOE-contractor laboratories to assist in the evaluations.

Staff evaluated and commented on 10 standards for the following organizations:

- International Standards Organization 5 standards

- International Electrotechnical Commission 4 standards

- American National Standards Institute 1 standard

Staff members also commented on the U.S. Vote on Proposal for New Work Item - ISO/TC 85/SC2, "Wide Spectra for Calibrating Radioprotection Equipment," and an IAEA report on radiation protection principles. Comments were also provided on two draft NCRP documents and on changes proposed in draft 10 CFR 20 . ${ }^{\text {(a) }}$

\section{Accreditation of Instrument Performance and Calibration}

\section{K. L. Swinth}

The purpose of this task is to establish guidelines for accreditation of instrument performance and calibration for DOE facilities. A series of documents will be issued to control the use of instruments in terms of qualification, acceptance testing, calibration, calibration traceability, retesting. and source checking in the field. A committee of experts will be established to review these documents.

Concurrence on the review group was received from DOE.HQ, which recommended that PNL

(a) Draft 10 CFR 20. U.S. Nuclear Regulatory Commission (NRC). 1988. Standards for Protection Against Radiation.

U.S. Code of Federal Regulations. prepare and mail the questionnaire on instruments in use at DOE facilities.

Calculation of spectral degradation in calibration geometries is compiete and documentation is under way. Calibration wells, collimated sources, and free-in-air sources were considered. Data from a survey of instruments in use at DOE facilities were collected and compiled. A few facilities have yet to respond to the surveys. A statistician reviewed methods for testing calibration capability with instruments, calibration of go/no go instruments, methods of determining calibration frequency, and methods of combining errors.

\section{References}

Faust, L. G., L. W. Brackenbush, K. R. Heid, W. N. Herrington, J. L. Kenoyer, L. F. Munson, L. H. Munson, J. M. Selby, K. L. Soldat, G. A. Stoetzel, and R. J. Traub. 1988. Health Physics Manual of Good Practices for Plutonium Facilities. PNL-6534, Pacific Northwest Laboratory, Richland, Washington.

International Corrmission on Radiological Protection (ICRP). 1985. "Statement from the 1985 Paris Meeting of the International Commission on Radiological Protection." Journal of the Society for Radiological Protection. 4(2)87-88.

McCall, R. C., W. R. Casey, L. V. Coulson, J. B. McCaslin, A. J. Miller, K. F. Crook, and T. N. Simmons. 1988. Health Physics Manual of Good Practices for Accelerator Facilities. SLAC-327, Stanford Linear Accelerator Center, Palo Alto, California.

Mishima, J., J. Hunt, W. D. Kittinger, G. Langer, D. Ratchford, P. D. Ritter, D. Rowan, and R. D. Stafford. 1988. Health Physics Manual of Good Practices for the Prompt Detection of Airborne Plutonium in the Workplace. PNL-6612, Pacific Northwest Laboratory: Richland, Washington.

Mishima, J., J. M. Selby, T. P. Lynch, G. Langer, and E. J. Vallario. 1987. "Airflow Patterns in Complex Workplaces." Paper presented at the American Nuclear Society Winter Meeting, November 15-19, 1987, Los Angeles, California.

Munson, L. H., W. N. Herrington, D. P. Higby, R. L. Kathren, S. E. Merwin, and G. A. Stoetzel. 1988. Health Physics Manual of Good Practices for Reducing Radiation Exposure to As Low As Reasonably Achievable (ALARA). PNL-6577, Pacific Northwest Laboratory, Richland, Washington. 
National Council on Radiation Protection and Measurements (NCRP). 1987. Recommendations on Limits for Exposure to lonizing Radiation. NCRP Report No. 91, National Council on Radiation Protection and Measurements, Bethesda, Maryland.

Patridge, M. D., and S. E. Merwin. 1988. Nineteenth Annual Report - Radiation Exposures for DOE and DOE Contractor Employees - 1986. PNL-6489, Pacific Northwest Laboratory, Richland, Washington.

Rich, B. L., S. L. Hinnefeld, C. L. Lagerquist, W. G. Mansfield, L. H. Munson, and E. R. Wagner. 1988. Health Physics Manual of Good Practices for Uranium Facilities. EGG-2350, Idaho National Engineering Laboratory, Idaho Falls, Idaho.

Selby, J. M., J. Mishima, and K. L. Swinth. 1988. "Air Sampling and Air Monitoring Standaids and Methodology." Continuing Education Course presented at the 33rd Annual Meeting of the Health Physics Society, July 4-8, 1988, Boston, Massachusetts.
Swinth, K. L., and D. R. Sisk. 1987, "Computer Controlled Testing and Calibration of Health Physics Instruments." Paper presented at the Institute of Electrical and Electronics Engineers, Inc., 1987 Nuclear Sciences Symposium, October 21-23, 1987, San Francisco, California.

Swinth, K. L., P. L. Phelps, W. N. Tyree, and J. L. Kenoyer. 1987. "New Developments in Continuous Monitoring of Airborne Activity." Paper presented at the American Nuclear Society Winter Meeting, November 15-19, 1987, Los Angeles, California. 


\title{
Department of Energy Laboratory Accreditation Program Technical Development and Application
}

\author{
Project Manager: J. C. McDonald
}

A national approach to quality assurance and accreditation of personnel dosimetry services for U.S. Department of Energy (DOE) laboratories is being implemented through the DOE Laboratory Accreditation Program (DOELAP). The program involves operating a performance-testing laboratory located at the Radiological and Environmental Sciences Laboratory (RESL) in Idaho Falls and conducting a technical application program at the Pacific Northwest Laboratory (PNL). The total effort encompasses 1) development of improved accreditation methods, 2) intercomparison of DOE radiological calibration standards using round-robin exchanges of instruments and sources, and 3) determination of the impact of new regulations and standards, including the development of calibration techniques that are needed to meet such standards.

The fiscal year (FY) 1988 effort included 1) development of a performance criteria for high-energy neutron dosimeters, 2) investigation of the impact of the recommendations of Report 39 of the International Commission on Radiation Units and Measurements (ICRU 1985) on DOE calibrations, 3) operation of a calibration intercomparison program for DOE laboratories, and 4) the recommendation of a set of performance criteria for angular response of personnel dosimeters. Progress made on these tasks during FY 1988 is discussed in the following sections.

\section{High-Energy Neutron Category}

\section{J. C. McDonald and K. L. Jones ${ }^{(a)}$}

Current DOELAP standards do not include a category for high-energy neutrons. Such a category is needed for evaluating performance of personnel dosimeters in high-energy environments such as might be encountered at accelerators.

A first draft of a DOELAP category for high-energy neutrons was prepared and sent to several representatives of DOE accelerator facilities asking for their written comments. Subsequently, a revised version was assembled and distributed in February. Discussions were also held with the RESL performance-testing laboratory staff about plans for the DOE standard for performance testing of personnel dosimetry systems (DOE 1986).

The consensus viewpoint of the respondents was that the use of an ${ }^{24} \mathrm{Am}-\mathrm{Be}$ neutron source for the DOELAP neutron-testing category would not be desirable. it was their opinion that the spectrum would not be sufficiently different from ${ }^{252} \mathrm{Cf}$, and that difficulties encountered with ${ }^{211}$ Am-Be, such as low dose rate, would present practical problems. A letter report was prepared suggesting that the existing DOELAP neutron categories remain unchanged, but informal

(a) Current address: 10865-B Chase Park Lane, St. Louis, Missouri 63141. discussions will continue on the topic of a suitable source for accelerator personnel neutron dosimeters.

\section{ICRU 39 Impact Studies}

\section{J. C. McDonald}

In 1985, ICRU issued a new ICRU Report 39 (ICRU 1985). This report includes definitions of four new quantities for monitoring radiation to the trunk of the body. These quantities are meant to supersede and replace the previously employed quantities, dose equivalent index, shallow- and deep-dose equivalent index, and shallow- and deep-dose equivalent, some of which are used in the current or draft DOE orders. The new quantities refer to the two basic measurement situations in radiation protection: environmental area monitoring and individual monitoring. These measurements are carried out by instruments and dosimeters, respectively, and will require extensive changes in the radiation measurement program in addition to possible changes in the units of occupational radiation measurement used by DOE.

Basically, all occupational radiation measurements are to be made using one of the four units, depending on whether the measuring device is a dosimeter or an instrument and whether the purpose of the measurement is to determine the 
penetrating or nonpenetrating components of dose equivalent.

The previous dose equivalent unit for photons was related to exposure in air and corrected to dose equivalent on a phantom using correction factors called $C_{x}$ values. The new units are based on air kerma and different $C_{x}$ values to compute dose equivalent in the ICRU sphere.

The radiation units previously recommended by the ICRU and currently used by DOE included the Roentgen, the rad, and the rem. In the old system, these units were used interchangeably, because they were all approximately equal for $x$ rays and gamma rays. In the new system, this is no longer true because of the conversion factors necessary to calculate dose equivalent from exposure ( $C_{x}$ factors). Although the new units are somewhat more complex, they are more accurate because they take into account the radiation that is backscattered from a person's body.

investigations will be conducted in $F Y 1989$ to determine the potential impacts of ICRU 39 on dosimeter and instrument designs, on development of correction factors to ensure continued use of a standard slab phantom at $\mathrm{DOE}_{\text {, }}$ on changing the standardization of all instrument and dosimeter calibration procedures, and on preparation of documentation such as manuals of good practices and handbooks.

To determine the effect of the changes in applying the new units to phantom radiation, the $C_{x}$ values used in the DOELAP manual must be compared with the "unified conversion factors" reported by the Federal Republic of Germany and the United Kingdom (Wagner et al. 1985). These measurements will allow for determination of the differences between the slab and sphere geometries. This comparison shows a difference of 10 to $25 \%$, with the greatest difference associated with lowenergy photons. Prelininary measurements of shallow $\mathrm{C}_{\mathrm{x}}$ factors for a phantom simulating the ICRU sphere show good agreement with the values of Wagner et al. (1985). Similar measurements are planned for the DOELAP slab phantom.

Recommendations and conclusions have been summarized in the draft report for this project. The draft report was delayed to include additional calculations that were necessary to relate exposures on DOELAP phantoms to the ICRU sphere. A complete draft report was sent to DOE Headquarters for review.

\section{Intercomparison Progress}

\section{F. M. Cummings ${ }^{(a)}$ and J. C. McDonald}

A program was initiated in $F Y 1986$ under DOELAP to routinely compare radiation calibrations. The objectives of the intercomparison program were to: provide standard measurement techniques that allow DOE laboratories to assess and improve the accuracy of radiation calibration sources, provide a database for recommending improvernents in calibration techniques and units generally applicable to all DOE facilities, and provide a forum for addressing problems and potential problems relating to radiation calibrations. During FY 1988, the intercomparison of radiation calibration standards in DOE facilities continued with the shipment of radiationmeasuring instruments and a beta calibration source set.

During FY 1988, there were 10 requests for the instrument sets and 2 for the beta set. (Use of the sets is scheduled up to a year in advance.) Of the laboratories that requested the intercomparision sets, results were reported for five that used the instruments and for one that used the beta set. The participants who did not report results failed to do so because of last-minute problems in scheduling personnel and facilities for conducting the intercomparison.

\section{Angular..Dependence Category}

K. L. Jones, R. A. Fox, F. M. Cummings, and J. C. MCDonald

Performance criteria for angular response of personnel dosimeters were developed to supplement DOE/EH-0027, the DOE standard for performance testing of personnel dosimetry systems (DOE 19186). The recommended criteria will be subject to peer review and pilot testing before their inclusion in the standard (DOE 1986)

Specifications of the DOE standard (DOE 1986) include the requirement to measure the angular responsts of personnel dosimeters relative to deliverect dose equivalent at perpendicular incdence for angles between $0^{\circ}$ and $85^{\circ}$. No performance criteria are currently specified. To establist performance criteria, it is necessary to determire the appropriate dose equivalent asisigned as a function of incident angle. The

(a) Curent address: U.S. Department of Energy, Radiclogical arıd Environmental Sciences Laboratory-CF690, 785 DOE Jace, Idaho Falls, Idaho 83402 
operational quantities used to assign delivered dose equivalent will significantly impact the design of future dosimetry systems.

Traditionally, dosimeter response at non-zero angles has been compared with delivered dose equivalent at perpendicular incidence. This approach results in extreme conservatism when estimating the dose equivalent in an isotropic environment. In most cases, movement of a worker within the radiation environment results in a field impinging on the worker from many directions relative to the dosimeter position. The ICRU recommends measuring individual dose equivalent below a specified point on the body at the appropriate measurement depth. If the specified point on the body is understood to be the location of the dosimeter, then a new set of dose equivalent quantities must be determined. The directional dose equivalent is an appropriate model for assigning dose equivalent at non-zero anyles of incidence.

Criteria are required to determine whether dosimeter performance is acceptable at non-zero angles. These criteria can be applied regardless of the model chosen to assign dose equivalent. The International Cornmission on Radiological Protection (ICRP) recommends accuracy within a factor of 1.5 (ICRP 1982). Although this factor seems large, it must encompass uncertainties due to energy response, angular response, and random system variability. Criteria for angular response can be developed, consistent with existing DOE criteria for response at perpendicular incidence and with ICRP recommendations (ICRP 1982).

Two algorithms were proposed to meet the ICRP recommendations for accuracy. Each included a weighted bias representing the difference between reported dose equivalent and delivered directional dose equivalent. Weighting factors were applied to compensate for the reduction in delivered dose equivalent at angles near $90^{\circ}$. Dosimeters from five laboratories were evaluated using the proposed criteria. For photons, the weighted bias and standard deviation were determined using directional dose equivalent in the ICRU sphere. Avallable data were too limited to assign directional dose equivalent for neutrons and beta particles. Calculating and measuring directional dose equivalent have been proposed as part of future research efforts to supplement existing data.
The findings, recommendations, and conclusions were published as Pertormance Criteria for Dosimeter Angular Response (Jones et al. 1988).

\section{Supplemental Tasks}

R. A. Fox, J. C. McDonald, F. M. Cummings, F. N. Eichner, R. T. Hogan, C. D. Hooker, K. L. Jones, and J. A. Leonowich

The PNL calibration facilities were upgraded with several improvements including a new k-fluorescence $x$-ray-generating assembly. This new $x$-ray source is expected to increase the dose equivalent rate capability and provide a cleaner $x$-ray spectrum. Additionally, the beta irradiation facility was expanded to allow for simultaneous irradiations at two stations.

\section{References}

International Commission on Radiation Units and Measurements (ICRU). 1985. Determination of Dose Equivalents Resulting from External Radiation Sources. ICRU Report 39, International Commission on Radiation Units and Measurements, Bethesda, Maryland.

International Commission on Radiological Protection (ICRP). 1982. General Principles of Monitoring for Radiation Protection of Workers. ICRP Publication 35, Pergamon Press, New York, New York.

Jones, K. L., P. L. Roberson, R. A. Fox, F. M. Cummings, and J. C. McDonald. 1988. Performance Criteria for Dosimeter Angular Response. PNL-6452, Pacific Northwest Laboratory, Richland, Washington.

U. S. Department of Energy (DOE). 1986. Department of Energy Standard for the Performance Testing of Personnel Dosimetry Sys. tems. DOE/EH-0027, U.S. Department of Energy, Washington, D.C.

Wagner, S. R., B. Grosswendt, J. R. Harvey, A. J. Mill, H. J. Selbach, and B. R. L. Sieberi. 1985. "Unified Conversion Functions for the New ICRU Operational Radiation Protection Quantities." Radiation Protection Dosimetry. 12(2):231-235. 



\title{
Internal Dosimetry Evaluation and Upgrade
}

\author{
Project Managers: L. G. Faust and D. R. Fisher
}

The Internal Dosimetry Evaluation and Upgrade Project is a multilaboratory research effort to improve internal dosimetry at U.S. Department of Energy (DOE) and DOE-contractor laboratories. Internal dosimetry is the science of determining radiation doses to organs and tissues from internally deposited radioactive materials. This includes the analysis of the intake of radioactive materials, their redistribution in body fluids, tissues, and organs, and their rate of excretion from the body. Estimating intake also involves measurement of radionuclides in the body by external counting and measurement of radionuclides in bioassay samples.

Studies to improve internal dose assessment are in progress at the Pacific Northwest Laboratory (PNL) and at several other supporting DOE laboratories and universities. The following sections describe progress made during fiscal year (FY) 1988 on selected tasks.

\section{Guide to Implementation of DOE Orders for Internal Dosimetry}

R. M. Hall and T. R. LaBone (SRP), D. R. Fisher and M. J. Sula (PNL), J. S. Bogard (ORNL), W. D. Fairman (ANL), R. B. Falk (RFP), J. D. Foulke (DOE), J. N. P. Lawrence (LANL), E. T. Lessard (BNL), and A. N. Tschaeche (WINCO)

An Internal Dosimetry Expert Group was formed in 1987 to develop guidance for implementation of draft DOE 5480.11 internal dosimetry program requirements. The Expert Group studied draffs of DOE 5480.11 (unpublished) and recommended suitabie methods for implementation of the requirements.

The Expert Group prepared a guide to provide uniform methods for assessing and limiting the occupational effective dose equivalent received by radiation workers from internally deposited radionuclides. One of the major issues addressed was the performance capability required for prospective monitoring of the workplace. The Expert Group determined that an internal exposure monitoring program should be capable of identifying the occurrence of exposures during a year that could result in an annual effective dose equivalent in excess of $2 \%$ of the exposure limits specified in RL 5480.1A (DOE-RL 1981).

The Exper Group recommended that all confirmed intakes of radionuclides, regardless of magnitude, should be evaluated, and that results of all bioassay and other measurements used to document occupational exposure should be recorded and maintained for future inspection. Prompt follow-up actions are necessary to confirm the initial indication of an internal exposure, to ascertain the significance of the exposure, and to provide sufficient data for dose assessment. However, committed dose equivalent values less than 2 mrem were not considered to be important for record-keeping purposes.

The recommendations of the Expert Group were not finalized during FY 1988 because the draft DOE 5480.11 was still undergoing revision. A final report will be completed during FY 1989.

\section{Chemical and Radiological Toxicities of Uranium}

K. F. Eckerman (ORNL)

The toxicity and biokinetics of uranium were studied under a task at Oak Ridge National Laboratory (ORNL). It involved review of recent data and potential changes in guidelines for occupational exposure implied by those data.

Two final reports were completed by ORNL during FY 1988. The first report, The Behavior and Chemical Toxicity of Uranium in the Kidney: A Reassessment, ${ }^{(a)}$ reviewed the biochemical toxicology of uranium at the membrane of kidney epithelial cells and provided estimates of minimum concentrations of uranium associated with functional damage. It also provided a mathematical model for the transporl and behavior of uranium in the kidneys.

The second report, Limits for Occupational Exposures to Uranium: A Comparison of Chemical and

(a) Leggett, R. W. 1988. "The Behavior and Chemical Toxicity of Uranium in the Kidney: A Reassessment." Heaith Physics (in press). 
Radiological ${ }^{(a)}$ proposed new annual limits on intake (ALIs) for occupational exposure to uranium. It indicated that previously published ALls for inhaled soluble forms of uranium may need to be reduced. Both reports were submitted for journal publication.

\section{Reference Man Database}

M. Cristy (ORNL)

A task is in progress at ORNL to revise the Reference Man (ICRP 1975) database. The Reference Man database is a fundamental starting point for internal dose calculations; it contains generic anatomical and physiological data on the human species.

The task group at ORNL collected and compiled 1175 documents from which the database was organized. The gross and elemental composition of the body received considerable emphasis. The concentrations of major (and trace) elements, as related to the amount of protein, water, and fat in various organs and tissues, were compiled. Work also proceeded on the anatomy and physiology of the gastrointestinat tract, including age-dependent definitions for transit times through various parts of the tract. Progress was also made on the skeleton, integumentary system (skin), skeletal muscles, urogenital system, and endocrine system.

The task group plans to complete the first draft of the Reference Man revision during calendar year 1989, after which it will be forwarded to the International Commission on Radiological Protection (ICRP) for review and approval.

\section{Ultrasound Measurement Techniques}

\section{A. L. Anderson (LLNL)}

New ultrasound methods are being developed at Lawrence Livermore National Laboratory (LLNL) to precisely determine the chest-wall thickness and fat content of subjects counted for plutonium and other transuranics in the lung. The task involves generating ultrasonic images followed by computer image processing and tissue characterization.

Most of the work at LLNL during the past year was directed toward evaluation and selection of

(a) Leggett, R. W. 1988. "Recommendations to the Department of Energy on Uranium Toxicity." Health Physics (in press). improved hardware and software for acquisition and processing of computer-enhanced sonic images. Notable progress was made in the application of pseudocolor as a means of improved tissue boundary definition, and in the measurement of fat content in the human chest wall. A special rnaterial, used as a stand-off pad when acquiring the sonic image, offers significant improvement in the accuracy of measurements of internal body structures, and will be recommended for future use at all DOE laboratories. Work on techniques for semiautomatic data reduction using computer graphics also showed promise. A complete data-reduction software package, suitable for distribution to other laboratories will be developed in early 1989 .

\section{Re-Evaluation of the Human Plutonium Injection Data of 1945-1946}

\section{W. D. Moss (LANL)}

The Langham power-function model appears to overestinate workers' plutonium depositions. A task continued this year at Los Alamos National Laboratory (LANL) to review, interpret, and correct notebook records of the original Langham plutonium injection data on human subjects. The purpose of this work is to develop an improved excretion model for plutonium that will permit better es:imates of workers' plutonium depositions based on bioassay excretion data and better correlation between human and animal excretion data.

\section{Technical Evaluation of Draft ANS! Standard N13.30 (Radiobioassay)}

\section{J. A. MacLellan and R. J. Traub}

The proposed American National Standards Institute (ANSI) Standard N13.30, "Performance Criteria for Radiobioassay"(b) provides minimum criteria for bias, accuracy, precision, and minimum detectable amount (MDA) for measurements of radioactivity in bioassay samples. The purpose of this task was to determine whether the criteria are adequate for DOE and NRC-licensee laboratories arid consisted of two rounds of bioassay laboratory performance testing. Participants included both in vitro (excreta analysis) and in vivo (external counting) measurements and evaluations. Analytical measurement results were

(b) Copies of Draft ANSI N13.30 are available from the Health Physics Society, 8000 Westpark Drive, Suite 400: McLean, VA 22102. 
evaluated for bias, precision, and minimum detectable amount.

The final report on fecal sample measurement quality was completed during FY 1989. An artificial feces matrix was developed for use in performance testing. Samples spiked with ${ }^{239} \mathrm{Pu}$ were distributed to nine participating facilities. This work showed that most participating laboratories were able to meet the performance criteria for measurement of ${ }^{239} \mathrm{Pu}$ in fecal samples.

A three-volume manual of recommended procedures for performance testing of radiobioassay laboratories was completed during FY 1988. The final report on in vitro measurement testing was published. The two-round intercomparison test of bioassay laboratories showed that performance criteria specified in the draft ANSI standard are reasonable. Failures by laboratories to meet the criteria were usually due to the choice of lessthan-optimum methods for sample analysis.

The second round of in vivo testing (involving whole body counting facilities) was not completed during FY 1988 due to delays by participating laboratories. Measurement results are expected from the remaining participants during FY 1989.

\section{Measurement of Transuranics in Workers}

\section{H. E. Paimer (PNL) and N. Cohen (NYU)}

The purpose of this task is to develop improved methods for determining transuranic radionuclides in the body and to construct realistic calibration phantoms from human bones containing known quantities of naturally metabolized transuranic radionuclides. The bones are embedded in a tissue-equivalent plastic material.

A calibration phantom was constructed at PNL and New York University (NYU) using bones from a total body donation to the U.S. Transuranium Registry. The right-side bones were previously analyzed radiochemically for ${ }^{241} \mathrm{Am}$ content, and the left-side bones were used to construct the calibration phantom. All of the phantom parts of this unit are now complete. The head, arm, torso, and leg parts are shown in Figure 1.

Synthetic phantom parts containing real bone with naturally incorporated ${ }^{241} \mathrm{Am}$ are useful for calibrating in vivo detectors used to measure ${ }^{241} \mathrm{Am}$ and ${ }^{239} \mathrm{Pu}$ in the skeleton. The phantoms are also useful for determining the number of counts during lung and liver measurements that originate from activity deposited in bone. Knowledge of these factors can greatly improve the sensitivity and accuracy of in vivo counting.

Work will continue during FY 1989 on construction of a new head phantom containing a skull from a radium dial painter. Phantom parts developed on this task are available, by loan, to other whole body counting facilities around the world.

\section{Resonantly Enhanced Collisional lonization}

\section{G. K. Gerke, B. A. Bushaw, and T. J. Whitaker}

The goal of this task is to develop an inexpensive and sensitive method for detecting very low levels of radionuclides in biological media using resonantly enhanced collisional ionization (RECl)

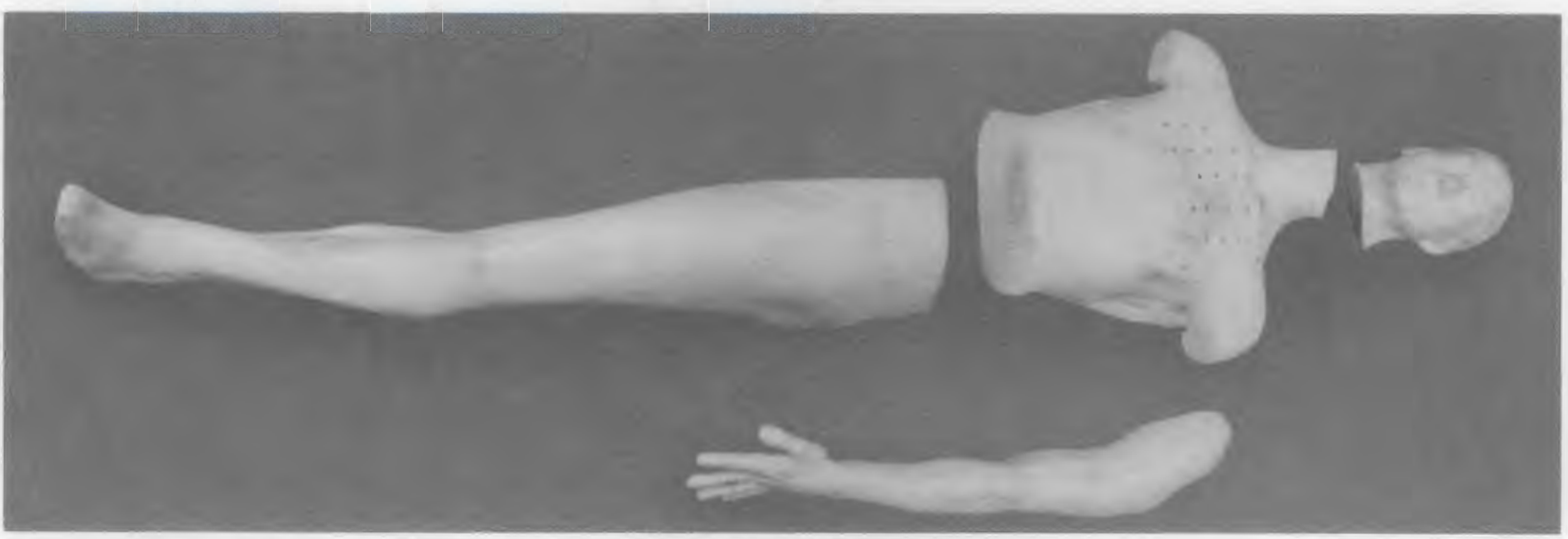

FIGURE 1. In Vivo Calibration Phantoms Containing Known Amounts of Naturally Metabolized ${ }^{241}$ Am in Bone 
methods. Proof-of-principle studies on calcium detection previously yielded promising results. This work showed $\mathrm{RECl}$ detection limits of approximately $100 \mathrm{fg}$, limited primarily by background calcium contamination.

Work continued during FY 1988 on detection of uranium by the $\mathrm{RECl}$ method. Detection limits of a few hundred picograms of uranium were obtained using a thermionic diode, but progress to further lower the detection limit was hampered by physical limitations--namely, the excessive background count rate at the high temperatures $\left(1700^{\circ} \mathrm{C}\right)$ needed to atomize the uranium samples.

A high vacuum with two dye lasers for resonant excitation of samples and a simple time-of-flight mass spectrometer were added to the $\mathrm{RECl}$ system to limit noise and increase measurement sensitivity.

A major breakthrough during FY 1988 involved the development of a sample-preparation procedure that allowed for reproducible evolution of atomic uranium for spectroscopy. Detection limits of $5 \mathrm{pg}$ were obtained for uranium using a singleresonance process $(424.626 \mathrm{~nm}$ dye laser, plus a $337.1 \mathrm{~nm}$ nitrogen ionizing laser) under high vacuum and using a channeltron detector. The detection sensitivity was improved to the femtogram level by adding a second, auto-ionizing resonance laser at $424.626 \mathrm{~nm}$.

A part of the auto-ionization spectrum for uranium detection is shown in Figure 2. The strong autoionizing resonances in the $51100-\mathrm{cm}^{-1}$ region were used for quantitative analysis. Improvements in the time-of-flight electronics should make it possible to further improve detection limit sensitivity.

Future work on this task will involve optimization of $\mathrm{RECl}$ measurement capabilities for measurement of plutonium atoms.

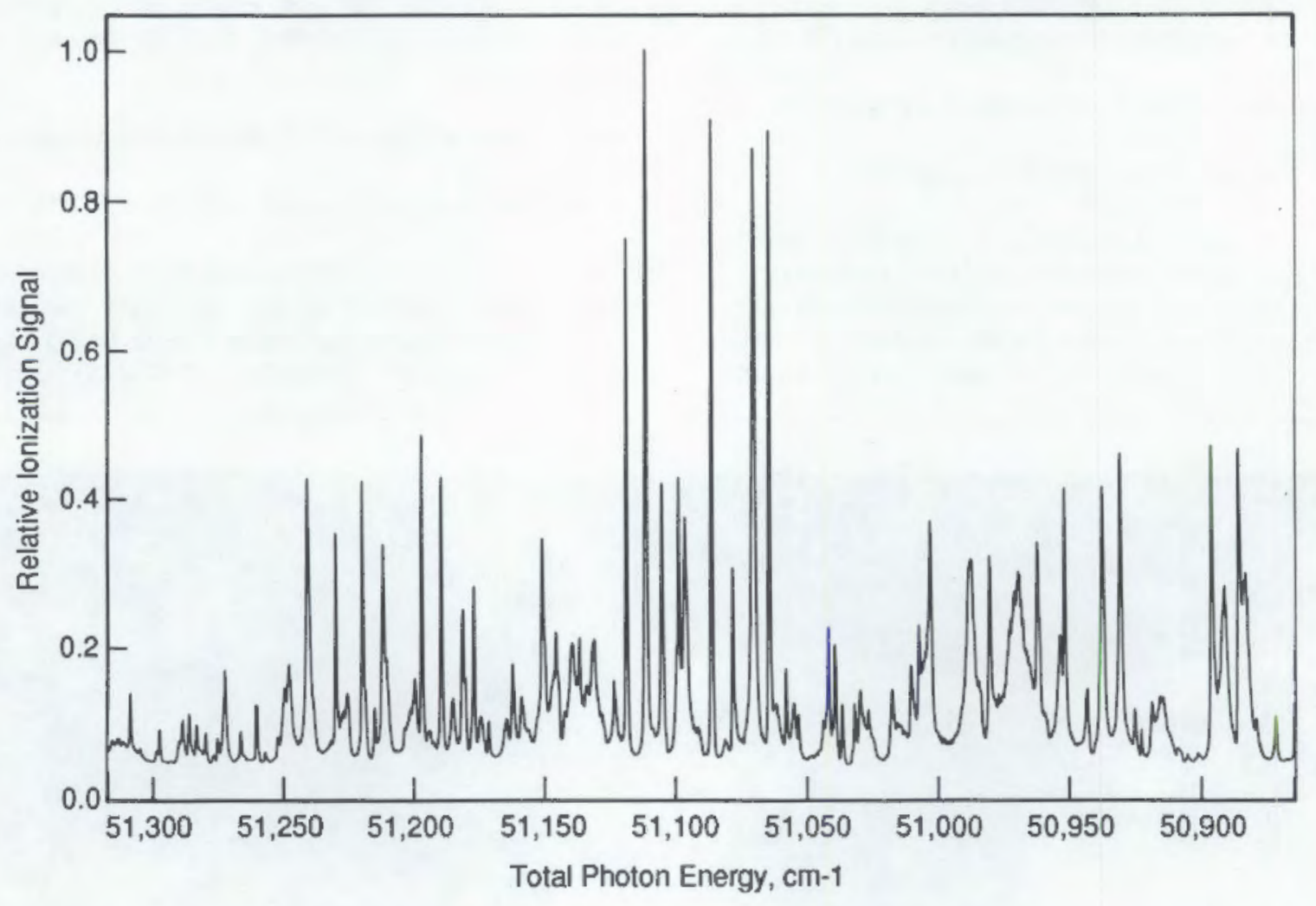

FGURE 2. Auto-lonizing Resonances of a Uranium Sample. The first excitation is a resonance step at $424.626 \mathrm{~nm}$, and a second dye laser scanned from 360.1 to $366.1 \mathrm{~nm}$ to obtain the total photon energy shown along the $\mathrm{x}$-axis. 


\section{References}

International Commission on Radiological Protection (ICRP). 1975. Report of the Task Group on Reference Man. ICRP Publication 23, Pergamon Press, New York, New York.

U.S. Department of Energy (DOE). 1981. Environmental Protection, Safety, and Health Protection Information Reporting Requirements. DOE 5484.1, U.S. Department of Energy, Washington, DC.
U.S. Department of Energy-Richland Operations (DOE-RL). 1981. Environmental Protection, Safety, and Health Program for DOE Operations. RL 5840.1A, U.S. Department of Energy, Richland Operations Office, Richland, Washington 



\section{ENVIRONMENT, SAFETY, AND TECHNICAL SUPPORT}

Project Manager: W. B. Scott

Under the Environment, Safety, and Health (ES\&H) Technical Support Project, Pacific Northwest Laboratory (PNL) provides the U.S. Department of Energy (DOE) ES\&H with technical support to 1) prepare technical information for responses to the Advisory Committee on Facility Safety (ACFS) and maintain a technical information interface, 2) prepare responses to congressional technical inquiries and requests for technical information from congressional committees, and 3) provide technical assistance to DOE ES\&H staft for the development of policy guides and safety standards.

\section{Technical Support}

A. S. Tabatabai

During FY 1988, PNL staff attended the ACFS meetings and assisted in the preparation of several draft policy statements, including the
Safety Policy Statement, the Safety Analysis Policy Statement, the Performance Policy Statement, the Safety Objectives Policy Statement, and the Backfit Policy Statement. Support was also provided in the preparation of the Human Factors Program Plan. 


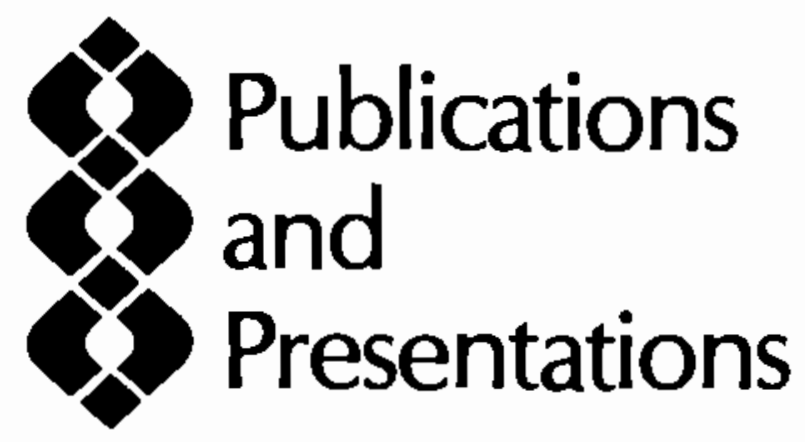




\section{PUBLICATIONS}

Brackenbush, L. W. 1987. "Determining Quality Factor and Effective Dose Equivalent for Neutrons." In Transactions of the American Nuclear Society, Winter Meeting. Vol. 55, pp. 2223, American Nuclear Society, Inc., La Grange Park, Illinois.

Brackenbush, L. W., G. W. R. Endres, W. D. Reece, J. S. Durham, S. D. Miller, and R. I. Scherpelz. 1988. A Field Neutron Spectrometer for Health Physics Apolications. PNL-6620 Vol. 2, Pacific Northwest Laboratory, Richland, Washington.

Brackenbush, L. W., W. D. Reece, S. D. Miller, G. W. R. Endres, J. S. Durham, and R. I. Scherpelz. 1988. A Field Neutron Spectrometer for Health Physics Applications. PNL-6510, Pacific Northwest Laboratory, Richland, Washington.

Cummings, F. M., and G. W. R. Endres. 1988. "U.S. Department of Energy Radiological Calibration Intercomparison Program." In Radiation Protection Practice (proceedings of the Seventh International Congress of the International Radiation Protection Association). Vol. I, pp. 6163, Australian Radiation Protection Society, Pergamon Press, Sydney, Australia.

Cummings, F. M., and J. C. McDonaid. 1988. DOE Radiological Calibrations Intercomparison Program: Results of Fiscal Year 1987. PNL-6583, Pacific Northwest Laboratory, Richland, Washington.

Faust, L. G., L. W. Brackenbush, K. R. Heid, W. N. Herrington, J. L. Kenoyer, L. F. Munson, L. H. Munson, J. M. Selby, K. L. Soldat, G. A. Stoetzel, and R. J. Traub. 1988. Health Physics Manual of Good Practices for Plutonium Facilities. PNL-6534, Pacific Northwest Laboratory, Richland, Washington.

Faust, L. G., B. L. Steelman, and J. M. Selby. 1988. Pacific Northwest Laboratory Annual Report for 1987 to the Assistant Secretary for Environment, Satety, and Health--Part 5, Environment, Safety, Health and Quality Assurance. PNL-6500 Part 5, Pacific Northwest Laboratory, Richland, Washington.
Faust, L. G., K. L. Swinth, C. M. Stroud, and E. J. Vallario. 1988. "The U.S. Department of Energy Personnel Dosimetry Evaluation and Upgrade Program." in Radiation Protection Practice (proceedings of the Seventh International Congress of the International Radiation Protection Association). Vol. I, pp. 444-447, Australian Radiation Protection Society, Pergamon Press, Sydney, Australia.

Hadlock, D. E., and M. A. Parkhurst. 1987. "Advances in the Development of CR-39 Based Neutron Dosimeters." In Aadiation Protection Practice (proceedings of the Seventh International Congress of the International Radiation Protection Association). Vol. f, pp. 299-301, Australian Radiation Protection Society, Pergamon Press, Sydney, Australia.

Hadlock, D. E., L. W. Brackenbush, L. G. Faust, M. A. Parkhurst, and C. M. Stroud. 1988. Personnel Neutron Dosimetry Assessment. PNL-6620 Vol 1, Pacific Northwest Laboratory, Richland, Washington.

Hankins, D. E. 1987. Personnel Neutron Dosimetry Using Electrochemically Etched CR-39 Foils. UCRL 95350, Lawrence Livermore National Laboratory, Livermore, California.

Hickman, D. P., and N. Cohen, 1988. "Reconstruction of a Human Skull Calibration Phantom Using Bone Sections from an Am-241 Exposure Case." Health Physics. 55:59-65.

Jones, K. L., P. L. Roberson, R. A. Fox, F. M. Cummings, and J. C. McDonald. 1988. Performance Criteria for Dosimeter Angular Response. PNL-6452, Pacific Northwest Laboratory, Richland, Washington.

Kennedy, W. E., Jr. 1988. "Potential Exposures from Uranium Enrichment." In Population Exposure From the Nuclear Fuel Cycle, (proceedings of the American Nuclear Society). Pp. 135-145, Gordon and Breach Science Publishers, New York, New York. 
Kennedy, W. E., Jr., and J. P. Corley. 1988. "Application of the ICRP Recommendations to Revised Secondary Radiation Protection Standards." Health Physics. 55(2):427-431.

Kennedy, W. E., Jr., C. R. Hemming, F. R. O'Donnell, and G. S. Linsley. 1988. "Applications of Exemption Principles to Low-Level Waste Disposal and Recycle of Wastes from Nuclear Faciilties." In Radiation Protection Practice (proceedings of the Seventh International Conference of the International Radiation Protection Association). Vol. 3, pp. 1235-1238, Australian Radiation Protection Society, Pergamon Press, Sydney, Australia.

Kennedy, W. E. Jr., and B. A. Napier. 1988. "Population Dose Considerations for Decommissioning." in Population Exposure From the Nuclear Fuel Cycle (proceedings of the American Nuclear Society). Pp. 195-204, Gordon and Breach Science Publishers, New York, New York.

Leggett, R. W. 1988. "The Behavior and Chemical Toxicity of Uranium in the Kidney: A Reassessment." Health Physics (in press).

Leggett, R. W. 1988. "Recommendations to the Department of Energy on Uranium Toxicity." Health Physics (in press).

MacLellan, J. A., D. R. Fisher, and R. J. Traub. 1988. Performance Testing of Radiobloassay Laboratories: In Vitro Measurement (Urinalysis), Final Report. PNL-6490, Pacific Northwest Laboratory, Richland, Washington.

MacLellan, J. A. 1988. Performance Testing of Radiobioassay Laboratories: in Vitro Measurements, Fecal Study Report. PNL-6601, Pacific Northwest Laboratory, Richland, Washington.

McCall, R. C., W. R. Casey, L. V. Coulson, J. B. McCasin, A. J. Miller, K. F. Crook, and T. N. Simmons. 1988. Manual of Good Practices for Radiation Protection at DOE Accelerator Facilities. SLAC-327, Stanford Linear Accelerator Center, Palo Alto, California.

Merwin, S. E., J. B. Martin, and R. C. Brown. 1988. "A Method for Optimizing the Use of Respiratory Protection in Radiation Areas." PNL-SA-16107. (Submitted to Radiation Protection Management.)
Merwin, S. E., and K. L. Swinth. 1987. Preliminary Investigation of the Suitability of Exoelectron Dosimeters for Personnel Beta Dosimetry. PNL-6370, Pacific Northwest Laboratory, Richland, Washington.

Miller, S. D., J. C. McDonald, G. W. R. Endres, and K. L. Swinth. 1988. "Cooled Optically Stimulated Luminescence in $\mathrm{CaF}_{2}: \mathrm{Mn}$." PNL-SA-15901. (Submitted to Radiation Protection Dosimetry.)

Mishima, J., J. Hunt, W. D. Kittinger, G. Langer, D. Ratchford, P. D. Ritter, D. Rowan, and R. D. Stafford. 1988. Health Physics Manual of Good Practices for the Prompt Detection of Airborne Plutonium in the Workplace. PNL-6612, Pacific Northwest Laboratory, Richland, Washington.

Mishima, J., J. M. Selby, T. P. Lynch, G. Langer, and E. J. Vallario. 1987. "Airflow Patterns in Complex Workplaces." In Transactions of the American Nuclear Society, Winter Meeting. Vol. 55, pp. 224-225, American Nuclear Society, Inc., La Grange Park, Illinois.

Munson, L. H., W. N. Herrington, D. P. Higby, R. L. Kathren, S. E. Merwin, and G. A. Stoetzel, 1988. Health Physics Manual of Good Practices for Reducing Radiation Exposure to Levels That Are As Low As Reasonably Achievable (ALARA). PNL-6577, Pacific Northwest Laboratory, Richland, Washington.

Northcult, A. R, S. E. Binney, and H. E. Palmer. 1988. "In Vivo Counting of Am-241 in Human Lungs and Tracheobronchial Lymph Nodes." Health Physics. 54:73-81.

Parkhurst, M. A. 1987. "Comparison of Neutron Track Detector Sensitivity as a Function of the Etching Process." In Radiation Protection Practice (proceedings of Seventh International Congress of the International Radiation Protection Association). Vol. 1, pp. 295-298, Australian Radiation Protection Society, Pergamon Press, Sydney, Australia.

Rich, B. L., S. L. Hinnefeld, C. L. Lagerquist, W. G. Mansfield, L. H. Munson, and E. R. Wagner. 1988. Health Physics Manual of Good Practices at DOE Uranium Facilities. EG\&G-2530, tdaho National Engineering Laboratory, Idaho Falls, Idaho. 
Selby, J. M. 1987. "Standards for Air Monitor Calibration." In Transactions of the American Nuclear Society, Winter Meeting. Vol. 55, p. 225, American Nuclear Society, Inc., La Grange Park, Allinois.

Selby, J. M., K. L. Swinth, and E. J. Vallario. "Instrumentation Research and Development in U.S. Department of Energy Health Physics Programs." In Radiation Protection Practice (proceedings of the Seventh International Congress of the International Radiation Protection Association). Vol. 1, pp. 48-51, Australian Radiation Protection Society, Pergamon Press, Sydney, Australia.

Selby, J. M., K. L. Swinth, and E. E. Hickey. "Comparison of U.S. and International Standards for Radiation Protection Instrumentation." In Radiation Protection Practice (proceedings of the Seventh international Congress of the International Radiation Protection Association). Vol. III, pp. 1275-1278, Australian Radiation Protection Society, Sydney, Australia.

Soldat, K. L., and G. W. R. Endres. 1987. "ALARA Practices During Neutron Dose and Energy Spectral Measurements Inside Reactor Containment." In Radiation Protection Practice (proceedings of the Seventh International Congress of the International Radiation Protection Association). Vol. I, p. 64, Australian Radiation Protection Society, Pergamon Press, Sydney, Australia.

Stephan, J. G., J. M. Selby, J. B. Martin, D. W. Moeller, and E. J. Vallario. 1987. "Emergency Planning Lessons Learned from a Review of Past Major Radiological Accidents." In Radiation Protection Practice (proceedings of the Seventh International Congress of the International Radiation Protection Association. Vol. II, pp. 980-983, Australian Radiation Protection Society, Pergamon Press, Sydney, Australia.
Swinth, K. L. 1988. "Radiation Measurement." BN-SA-2615. Guest editorial. Institute of Electrical and Electronic Engineers, Inc., Transaction on Nuclear Science 35(1):941.

Swinth, K. L., P. L. Phelps, W. N. Tyree, and J. L. Kenoyer. 1987. "New Developments in Continuous Monitoring of Airborne Activity." In Transactions of the American Nuclear Society, Winter Meeting, Vol. 55, p. 222, American Nuclear Society, Inc., La Grange Park, Illinois.

Swinth, K. L, D. R. Sisk, J. M. Selby, and E. J. Vallario. "Evaluation of the Instrument Correction Factors Needed in Beta Dosimetry." In Radiation Protection Practice (proceedings of the Seventh International Congress of the International Radiation Protection Association). Vol. I, pp. 68-71. Australian Radiation Protection Society, Pergamon Press, Sydney, Australia.

Tanner, J. E., W. D. Reece, and L. W. Brackenbush, and R. I. Scherpelz. 1987. "A I/V Absorber Detector for Measuring Neutron Spectra." In Radiation Protection Practice (proceedings of the Seventh International Congress of the International Radiation Protection Association). Vol. I, p. 304, Australian Radiation Protection Society, Pergamon Press, Sydney, Australia.

Welty, C. G., Jr., W. E. Kennedy, Jr., and K. A. Hawley. 1988. "Population Exposures From U.S. Department of Energy Operations." In Population Exposure From the Nuclear Fuel Cycle (proceedings of the American Nuclear Society). Pp. 245-257, Gordon and Breach Science Publishers, New York, New York. 


\section{PRESENTATIONS}

Brackenbush, L. W. 1987. "Determining Quality Factor and Effective Dose Equivalent for Neutrons." Paper presented at the American Nuclear Society Winter Meeting, November 15-19, 1987, Los Angeles, California.

Brackenbush, L. W., J. E. Tanner, W. D. Reece, and A. 1. Scherpelz. 1988. "Estimating Effective Dose Equivalent for Neutrons." Paper presented at the 33rd Annual Meeting of the Health Physics Sociefy, July 4-8, 1988, Boston, Massachusetts.

Buck, J. W., and J. G. Droppo. 1987. "Characterization of the Atmospheric Pathway at Hazardous Waste Sites." Paper presented at the DOE Modeling Conference, October 6, 1987, Oak Ridge, Tennessee.

Cummings, F. M., and J. C. McDonald. 1988. "U.S. Department of Energy Radiological Calibration Intercomparison Program." Paper presented at the Health Physics Society Symposium, December 4-8, 1988, San Antonio, Texas.

Endres, G. W. R. 1988. "U.S. Department of Energy Radiological Calibration Intercomparison Program." Poster session and paper presented at the 33rd Annual Meeting of the Health Physics Society, July 4-8, 1988, Boston, Massachusetts.

Faust, L. G. 1988. "Ouality Factors for Neutrons." Continuing Education Course presented at the 33rd Annual Meeting of the Health Physics Society, July 4-8, 1988, Boston, Massachusetts.

Faust, L. G., K. I. Swinth, C. M. Stroud, and E. J. Vallario. 1987. "The U.S. Department of Energy Personnel Neutron Dosimetry Evaluation and Upgrade Program." Paper presented at the Seventh International Congress of Radiation Protection and Dosimetry, October 31-November 4, 1987, Orlando, Florida.

Faust, L. G., K. L. Swinth, C. M. Stroud, and E. J. Vallario. 1988. "The U.S. Department of Energy Personnel Dosimetry Evaluation and Upgrade Program." Paper presented at the Seventh International Congress of the International Radiation Protection Association, April 10-17, 1988, Sydney, Australia.
Gerke, G. K., B. A. Bushaw, and J. T. Whitaker. 1988. "Low-Level Radionuclide Analysis Using Pesonantly Enhanced Collisional Ionization." Paper presented at the 4th International Symposium on Resonance Ionization Spectroscopy, April 10-15, 1988, Gaithersburg, Maryland.

Hankins, D. E. 1987. "Neutron SpectrumDependent Track-Size Distribution of Electrochemically Etched CR-39 Foils." Paper presented at the Sixth Symposium on Neutron Dosimetry, October 12-16, 1987, Neuherberg, Federal Republic of Germany.

Hankins, D. E. 1987. "The LLNL CR-39 Personnel Neutron Dosimeter." Paper presented at the Sixth Symposium on Neutron Dosimetry, October 12-16, 1987, Neuherberg, Federal Republic of Germany.

Hertel, N. E., and J. C. McDonaid. 1988. "Dose Equivalent and Phantoms in Conventional Calibration Practices." Paper presented at the American Nuclear Society Meeting, October 30, 1988, Washington, D.C.

Kennedy, Jr., W. E. 1988. "Current Status of the Development of International Exemption Principles." Paper presented at the Tenth Annual DOE Low-Level Waste Management Conference, August 30-September 1, 1988, Denver, Colorado.

Kennedy, Jr., W. E. 1988. "Intruder Scenarios for Site-Specific Waste Classification." Paper presented at the Tenth Annual DOE Low-Level Waste Management Conference, August 30September 1, 1988, Denver, Colorado.

Kennedy, W. E., Jr., C. R. Hemming, F. R. O'Donnell, and G. S. Linsley. 1988. "Application of Exemption Principles to Low-Level Waste Disposal and Recycle of Wastes from Nuclear Facilities." Paper presented at the Seventh International Congress of the International Radiation Protection Association, April 10-17, 1988, Sydney, Australia. 
MacLellan, J. A. 1987. "Performance Testing of Bioassay Laboratories Using an Artificial Fecal Matrix." Paper presented at the 33rd Annual Conference on Bioassay, Analytical, and Environmental Radiochemistry, October 6-8, 1987, Berkeley, California.

MacLellan, J. A., and R. J. Traub. 1988. "The Draft ANSI N13.30 Minimum Detectable Amount Test Criterion for Radiobioassay Laboratories." Paper presented at the 33rd Annual Meeting of the Health Physics Society, July 4-8, 1988, Boston, Massachusetts.

McDonald, J. C. 1988. "Operation of a Proficiency Testing Laboratory for Radiation Dosimeters." Paper presented at the Annual Meeting of the National Conference of Standards Laboratories, August 14, 1988, Washington, D.C.

McDonald, J. C., and N. E. Hertel. 1988. "Calcufations of Dosimetric Ouantities for ${ }^{252} \mathrm{Cf}$ Neutron Sources." Paper presented at the 33rd Annual Meeting of the Health Physics Society, July 4-8, 1988, Boston, Massachusetts.

Miller, S. D., and P. L. Tomeraasen. 1988. "Super-Cooled Optically Stimulated Luminescence Dosimetry." Paper presented at the 33rd Annual Meeting of the Health Physics Society, July 4-8, 1988, Boston, Massachusetts.

Mishima, J., J. M. Selby, T. P. Lynch, G. Langer, and E. J. Vallario. 1987. "Airflow Patterns in Complex Workplaces." Paper presented at the American Nuclear Society Winter Meeting, November 15-19, 1987, Los Angeles, California.

Parkhurst, M. A. 1988. "Detecting Low-Energy Neutrons Using CR-39 with Boron Radiators." Paper presented at the 33rd Annual Meeting of the Health Physics Society Annual Meeting, July 4-8, 1988, Boston, Massachusetts.

Ramsdell, J. V. 1988. "Diffusion in Building Wakes." Paper presented at the American Nuclear Society Meeting, September 26-28, 1988. Charleston, South Carolina

Scherpelz, R. I., J. E. Tanner, L. W. Brackenbush, and W. D. Reece. 1988. "The Sensitivity of EHective Dose Equivalent to Calculational Assumptions." Paper presented at the 33rd Annual Meeting of the Health Physics Society, July 4-8, 1988, Boston, Massachusetts.
Selby, J. M. 1987. "Standards for Air Monitor Calibration." Paper presented at the American Nuclear Society Winter Meeting, November 15-19, 1987, Los Angeles, California.

Selby, J. M., J. Mishima, and K. L. Swinth. 1988. "Air Sampling and Air Monitoring Standards and Methodology." Continuing Education Course presented at the 33rd Annual Meeting of the Health Physics Society, July 4-8, 1988, Boston, Massachusetts.

Selby, J. M., W. E. Kennedy, K. L. Swinth, R. O. Gilbert, and J. K. Soldat. 1988. "Practical Considerations in the Development and Application of Reference Levels." Paper presented at the Classified NATO Meeting, July 18-22, 1988, Paris, France.

Selby, J. M., K. L. Swinth, and E. E. Hickey 1987. "Comparison of U.S. and international Standards for Radiation Protection Instrumentation." Paper presented at the Seventh International Congress of the International Radiation Protection Association, April 10-17, 1988, Sydney, Australia.

Selby, J. M., K. L. Swinth, and E. J. Vallario. 1988. "Instrumentation Research and Development in U.S. Department of Energy Health Physics Programs." Paper presented at the Seventh International Congress of the International Radiation Protection Association, April 10-17, 1988, Sydney, Australia.

Sisk, D. R., and K. L. Swinth. 1988. "Ion Chamber Response Calculations Based on Beta Radiation Simulations." Poster and paper pre. sented at the 33rd Annual Meeting of the Health Physics Society, July 4-8, 1988, Boston, Massachusetts.

Stephan, J. G., J. M. Selby, J. B. Martin, D. W Moeller (Harvard), and E. J. Vallario. 1988 "Emergency Planning Lessons Learned from a Review of Past Major Radiological Accidents." Paper presented at the Seventh International Congress of the International Radiation Protection Association, April 10-17, 1988, Sydney, Australia

Swinth, K. L., and S. E. Merwin. 1988 "Energy-Independent Occupational Dose Measurements Using an Exoelectron Dosimeter Badge." Paper presented at the 33rd Anrual Meeting of the Health Physics Society: July 4-8, 1988, Boston, Massachusetts. 
Swinth, K. L., P. L. Phelps, W. N. Tyree, and J. L. Kenoyer. 1987. "New Developments in Continuous Monitoring of Airborne Activity." Paper presented at the American Nuclear Society Winter Meeting, November 15-19, 1987, Los Angeles, California.

Swinth, K. L., and D. R. Sisk. "Computer Controlled Testing and Calibration of Health Physics Instruments." Paper presented at the Institute of Electricai and Electronics Engineers, Inc. 1987 Nuclear Sciences Symposium, October 21-23, 1987, San Francisco, California.
Tanner, J. E. 1988. "The Effect of Gender and Remainder on Effective Dose Equivalent." Paper presented at the American Nuclear Society/ European Nuclear Society 1988 International Conference, October 30-November 3,1988 , Washington, D.C. 

Author 


\section{AUTHOR INDEX}

Abashian, M. S.; 9

Anderson, A. L. (LLNL); 40

Anderson, T. L.; 13

Apfel, R. E. (Apfel

Enterprises); 20

Arnold, L. H.; 8

Baker, D. A.; 13

Baum, J. W. (BNL); 29

Bogard, J. S. (ORNL); 39

Brackenbush, L. W.; 18, 21

Bramson, P. E.; 4

Brockhaus, R. D.; 10

Buck, J. W.; 8, 10

Bushaw, B. A; 41

Cohen, N. (NYU); 41

Coulson, L. M. (Fermi); 21

Cummings, $F$. $M_{i} ; 36,37$

Cristy, M. (ORNL); 40

Daniel, J. L.; 8

Doctor, P. G.; 7

Droppo, J. G.; 7, 8, 10

Durham, J. S.; 23

Eckerman, K. F. (ORNL); 39

Eichner, F. N.; 37

English, S. L.; 8

Fairman, W. D. (ANL); 39

Falk, R. B. (RFP); 39

Faust, L. G.: 17, 21, 23, 29 , 30,39

Fisher, D. R.; 30,39

Foulke, J. D. (DOE); 39

Fox, R. A.; 36, 37

Friedrichs, D. R; 8

Gebhart, J. E.; 8

Gerke, G. A.; 41

Grove, L. K; 3

Hadlock, D. E.; 21

Hall, R. M. (SRP); 39

Hankins, D. E. (LLNL); 17
Harty, R.; 32

Hickey, E. E.; 4, 31

Higby, D. P.; 13

Higley, K. A.; 4, 7, 8, 10

Hilmas, D. E.; 8

Hogan, R. T.; 37

Hooker, C. D.; 37

Hoopes, B. L.; 8,10

Huang, S. J. (UCONN); 17

Huizenga, D. G.; 11

Johnson, J. F.; 17

Johnston, B. V.; 13

Jones, K. L.; 35, 36, 37

Kennedy, Jr., W. E.; 3, 4

Kirby, L. J.; 8

LaBone, T. R. (SRP); 39

Lamar, D. A.; 13

Latkovich, J. L.; 8

Lawrence, J. N. P. (LANL); 39

Leonowich, J. A.; 37

Lessard, E. T. (BNL); 39

MacLellan, J. A.; 40

Martin, J. B.; 29

McAtee, G. A.; 8

McCall, R. C. (SLAC); 21

McCormack, W. D.; 3

McCoy, E. J.; 8

McDonald, J. C.; 35, 36, 37

McNeill, D. A.; 13

Merwin, S. E.; 23, 29

Miley, T. B.; 7

Miller, S. D.; 17, 19, 23

Mishima, J.; 3,31

Moe, H. J. (ANL); 21

Moss, W. D. (LANL); 40

Nelson, 1. C.; 4

Oberlander, P. L.; 7

Owens, R. A.; 8

Palmer, H. E.; 41
Parkhurst, M. A.; 17, 21

Peloquin, R. A.; 3,4

Raichart, D. W.; 8

Ramsdell, J. V.; 3

Reece, W. D.; 18, 26, 32

Roth, D. R.; 8

Rosbach, M. L.; 13

Scherpeiz, R. I.; 18, 21

Schreckhise, R. G.; 13

Scoth, W. B.; 45

Selby, J. M:; 29, 30, 31, 33

Simpson, D. R:; 13

Sisk, D. R.; 20, 26, 31

Soldat, J. K; 3,4

Steelman, B. L.; 10

Stenner, R. D.; 3, 4, 13

Stephan, J. G.; 29, 30, 33

Stoetzel, G. A.; 31

Strenge, D. L.; 7, 10

Stroud, C. M.; 17, 20, 21

Sula, M. J.; 39

Swinth, K. L.; 20, 23, 26, 31,33

Tabatabai, A. S.; 45

Tanner, J. E; 18

Templeton, W. L.; 3

Thorngate, J. H. (LLNL); 18

Tinker, M. R.; 31

Tschaeche, AIN. (WINCO); 39

Traub, R. J.; 30,40

Turner, J. E. (ORNL); 21

Valdez, L. M: 13

Walter, M. B.; 8,10

Whelan, G.; 7, 8, 10

Whitaker, T. J.; 41

Wilbur, J. S.: 7

Woodruff, W. G.; 13 



\section{DISTRIBUTION}

PNL-6800 Pt. 5

UC-407

\section{OFFSITE}

G. E. Adams, Director Medical Research Council Radiobiology Unit Harwell, Didcot Oxon OX11 ORD ENGLAND

\author{
R. J. Aiken \\ U.S. Department of Energy \\ 1000 Independence \\ Avenue, SW \\ Washington, DC 20585 \\ W. R. Albers \\ U.S. Department of Energy \\ EH-12, GTN \\ Washington, DC 20545 \\ T. W. Ambrose \\ Battelle - Seattle \\ 4000 NE 41st Street \\ P.O. Box 5395 \\ Seattle, WA 98105.5428
}

A. L. Anderson Lawrence Livermore National Laboratory, L-383

P.O. Box 5505

Livermore, CA 94550

\section{Anderson}

ENVIROTEST

1108 NE 200th Street

Seattle, WA 98155-1136

D. C. Aumann Institut für Physikalische Chemie

Universität Bonn

Abt. Nuklearchemie

Wegeterstrasse 12

5300 Bonn 1

FEDERAL REPUBLIC OF GERMANY

\section{J. A. Auxier}

IT/Radiological Services Laboratory

1550 Bear Creek Road

P.O. Box 549

Oak Ridge, TN 37831

\author{
F. Badgley \\ 13749 NE 41st Street \\ Seattle, WA 98125 \\ M. R. Balakrishnan, Head \\ Library \& Information \\ Services \\ Bhabha Atomic Research \\ Centre \\ Central Complex \\ Trombay, Bombay-400 085 \\ INDIA \\ R. W. Barber \\ U.S. Department of Energy \\ EH-131, GTN \\ Washington, DC 20545
}

A. D. Barker
Battelle Columbus
Laboratories
505 King Avenue
Columbus, OH 43201

N. F. Barr

U.S. Department of Energy

ER-72, GTN

Washington, DC 20545

J. H. Barry

U.S. Department of Energy

Idaho Operations Office

785 DOE Place

Idaho Falls, ID 83402

J. K. Basson, Vice-President

Raad Op Atomic

Atoomkrag Energy Board

Privaatsk $X 256$

Pretoria 0001

REPUBLIC OF SOUTH AFRICA

J. W. Baum

Brookhaven National

Laboratory

Bidg 703-M

Upton, Long Island, NY 11973

E. C. Baynard III

U.S. Department of Energy

EH-1, FORS

Washington, DC 20585

\author{
A. M. Beau, Librarian \\ Département de Protection \\ Sanitaire \\ Commissariat à l'énergie \\ Atomique \\ BP No. 6 \\ F-92265 Fontenay-aux-Roses \\ FRANCE
}

G. Bengtsson, Director-General Statens Stralskyddsinstitut

Box 60204

S-104 01 Stockholm

SWEDEN

D. J. Beninson

Gerencia de Proteccion Radiológica y Seguridad

Comisión Nacional de Energía Atómica

Avenida del Libertador 8250

$2^{\circ}$ Piso Of. 2330

1429 Buenos Aires

ARGENTINA

S. O. W. Bergstrom

Aktiebolaget Atomienergi

Studsvik Energiteknik AB

Health and Safety Section

S-6 1182 Nykoping

SWEDEN

R. P. Berube

U.S. Department of Energy

EH-151, GTN

Germantown, MD 20545

A. Bianco International Atornic Energy Agency

Wagramerstrasse 5

P.O. Box 200

A-1400 Vienna

AUSTRIA

W. R. Bibb

U.S. Department of Energy

Energy Programs and Support

Division

P.O. Box B

Oak Ridge, TN 38731 


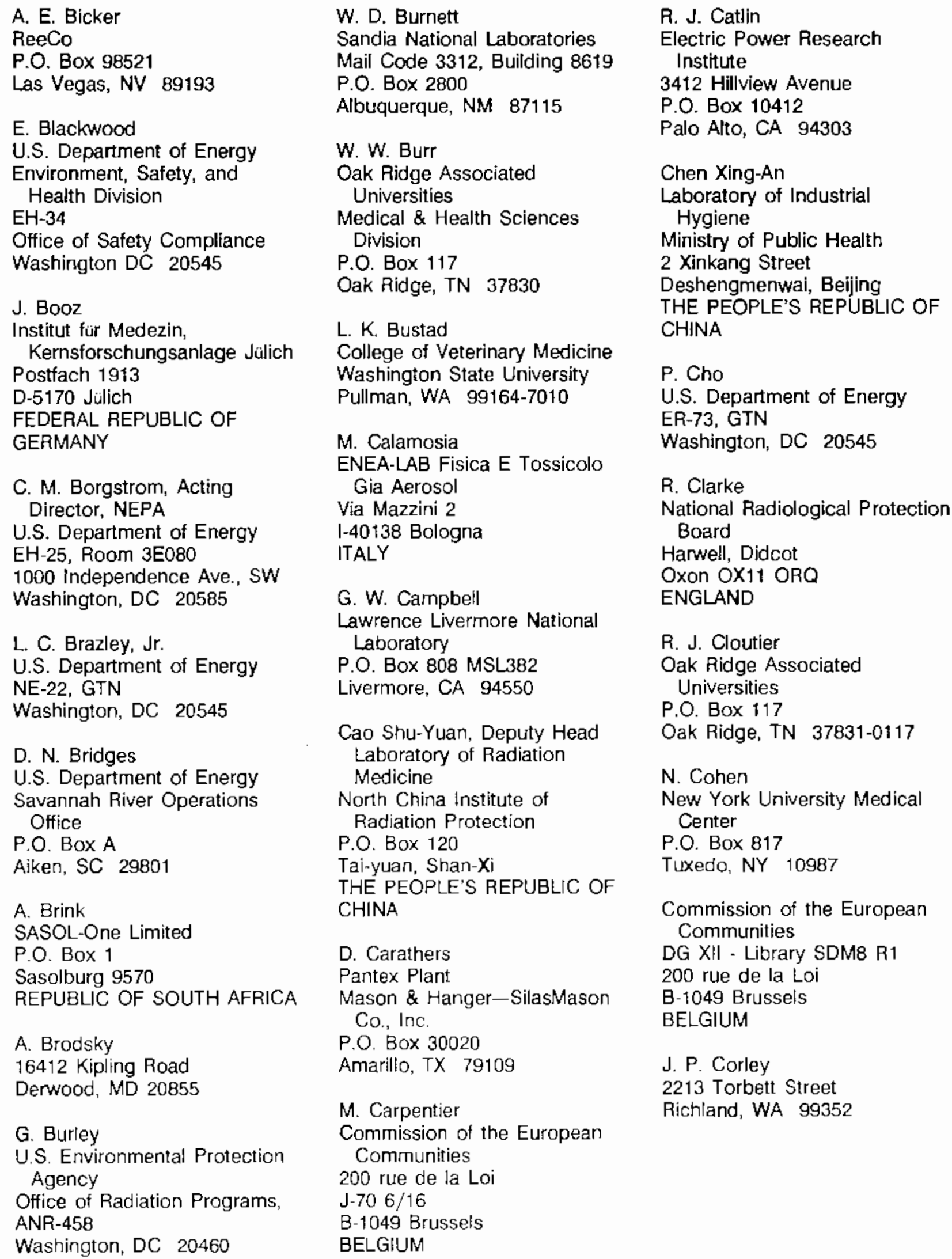


L. V. Coulson

Fermi National Accelerator Laboratory

P.O. Box 500

Batavia, IL 60510

Council on Environmental

Quality

722 Jackson Place, NW

Washington, DC 20503

\section{T. R. Crites}

Lawrence Livermore National

Laboratory, L-382

P.O. Box 808

Livermore, CA 94550

R. E. Cunningham

U.S. Nuclear Regulatory Commission

Washington, DC 20555

J. T. Davis

U.S. Depariment of Energy

San Francisco Operations

Office

1333 Broadway

Oakland, CA 94612

J. F. Decker

U.S. Department of Energy

ER-1, FORS

Washington, DC 20585

Deng Zhicheng

North China Institute of

Radiation Protection

Tai-yuan, Shan-Xi

THE PEOPLE'S REPUBLIC OF CHINA

G. DePlanque, Director

U.S. Department of EnergyEMEL

375 Hudson Street

New York, NY 10014

Director

Commissariat à l'ènergie

Atomique

Centre d'Etudes Nucléaires

Fontenay-aux-Roses (Seine)

FRANCE

\author{
Director \\ Commonwealth Scientific and \\ Industrial Research \\ Organization \\ Aspendal, Victoria \\ AUSTRALIA
}

Director

Laboratorio di Radiobiologia

Animale

Centro di Studi Nucleari Della

Casaccia

Comitate Nazionale per

l'Energia Nucleare

Casella Postale 2400

i-00100 Roma

ITALY

G. P. Dix

26619 Haney Avenue

Damascus, MD 20750

D. Djuric

Institute of Occupational and

Radiological Health

11000 Beograd

Deligradoka 29

YUGOSLAVIA

T. J. Dobry, Jr.

U.S. Department of Energy

DP-226.3, GTN

Washington, DC 20545

DOE/Office of Scientific \&

Technical Information (10)

J. W. Doty

Monsanto Research Corp.

Mound Laboratory

P.O. Box 32

Miamisburg, $\mathrm{OH} 45342$

H. Drucker

Argonne National Laboratory

9700 South Cass Avenue

Argonne, IL 60439

A. P. Duhamel

U.S. Department of Energy

ER-74, GTN

Washington, DC 20545
H. J. Dunster

National Radiological Protection Board

Chilton, Didcot

OxOn OX11 ORQ

ENGLAND

K. F. Eckerman

Oak Ridge National Laboratory

Health and Safety Research

Division

Health Studies Section

P.O. Box 2008

Oak Ridge, TN 37831-6383

G. A. Eisele

Oak Ridge Associated

Universities

Medical Division

P.O. Box 117

Oak Fidge, TN 37830

E. H. Eisenhower

National !nstitute of Standards

and Technology

Bldg. 245, Fm. C229

Gaithersburg, MD 20899

W. H. Ellett

BRER-National Research

Council, MH-370

2101 Constitution Avenue, NW

Washington, DC 20418

R. J. Engelmann

11701 Karen

Potomac, MD 20854

T. H. Essig

U.S. Nuclear Regulatory

Commission

Mail Stop 11-D-23

Washington, DC 20555

L. Feinendegen, Director Institut für Medezin.

Kernstorschungsanlage Jülich

Postfach 1913

D-5170 Jülich

FEDERAL REPUBLIC OF

GERMANY 
K. P. Ferlic

U.S. Department of Energy

Environment, Safety, and

Health Division

Office of Safety Policy

and Standards

EH 352

Washington, DC 20545

\section{Fitoussi \\ Commissariat à l'energie \\ Atomique \\ Département de Protection Sanitaire \\ BP No. 6 \\ F-92265 Fontenay-aux-Roses \\ FRANCE}

J. E. Fitzgerald, Jr., Director

U.S. Department of Energy

Environment, Safety, and

Health Division

Office of Safety Policy

and Standards

EH-35

Washington, DC 20545

P. K. Fitzsimmons

U.S. Department of Energy

Nevada Operations Office

P.O. Box 14100

Las Vegas, NV 89114

W. O. Forster

U.S. Department of Energy

ER/OHER/ERD

Washington, DC 20545

G. B. Gerber

Commission of the European

Communities

Radiobiology Department

200 rue de la Loi

B-1049 Brussels

BELGIUM

T. F. Gesell

U.S. Department of Energy

Idaho Operations Office

785 DOE Place

Idaho Falls, ID 83402-4149

G. W. Gibbs

U.S. Department of Energy

EH-151, GTN

Germantown, MD 20545
D. N. Gideon

Battelle Columbus Laboratories

505 King Avenue

Columbus, $\mathrm{OH} 43201$

R. D. Gilmore, President

Environmental Health Sciences, Inc.

Nine Lake Bellevue Building

Suite 104

Bellevue, WA 98005

M. Goldman

University of California

Department of Radiological

Sciences (VM)

Davis, CA 95616

R. Goldsmith

U.S. Department of Energy

ER-73, GTN

Washington, DC 20545

G. Goldstein

U.S. Department of Energy

ER-74, GTN

Washington, DC 20545

A. R. Gopal-Ayengar
73-Mysore Colony
Mahul Road, Chembur
Bombay-400 074
INDIA

R. V. Griffith

International Atomic Energy Agency

Wagramerstrasse 5

P.O. Box 200

A.1400 Vienna

AUSTRIA

B. K. Grimes

U.S. Nuclear Regulatory

Commission

Washington, DC 20555

G. H. Gronhovd

U.S. Deparlment of Energy

Grand Forks Energy Research Center

Box 8213, University Station

Grand Forks, ND 58202
R. M. Hall

Savannah River Laboratory

E. I. du Pont de Nemours \& Company

Aiken, SC 29801

R. E. Halliburton

Oak Ridge National Laboratory

P.O. Box X

Oak Ridge, TN 37830

D. H. Hamilton, Jr.

U.S. Department of Energy

ER-72, GTN

Washington, DC 20545

J. W. Healy

51 Grand Canyon Drive

White Rock, NM 87544

K. R. Heid

2318 Davison Avenue

Richland, WA 99352

S. L. Hinnefeld

Westinghouse Materials

Company of Ohio

P.O. Box 398704

Cincinnati, $\mathrm{OH} 45239$

D. B. Howard

U.S. Department of Energy

Oak Ridge Operations

Office

P.O. Box E

Oak Ridge, TN 38731

A. P. Hull

Brookhaven National

Laboratory

Safety and Environmental

Protection Division

Building 535.A

Upton, Long Island, NY 11973

R. A. Hunter

U.S. Department of Energy

NE-47, GTN

Washington, DC 20545 
F. Hutchinson

Department of Molecular Biophysics \& Biochemistry

Yale University

260 Whitney Avenue

P.O. Box 6666

New Haven, CT 06511

D. S. Ingle

U.S. Department of Energy

Albuquerque Operations

Office

Dayton Area Office

P.O. Box 66

Miamisburg, $\mathrm{OH} 45342$

H. Ishikawa, General Manager

Nuclear Safety Research

Association

P.O. Box 1307

Falls Church, VA 22041

W. Jacobi

Institut für Strahlenschutz

Ingolstadter Landstrasse 1

D-8042 Neuherberg

FEDERAL REPUBLIC OF

GERMANY

K. E. Lennart Johansson

National Defense Research

Institute

FOA 451

S-901-82 Umeả

SWEDEN

A. W. Johnson

Vice President for Academic Affairs

San Diego State University

San Diego, CA 92182

G. Y. Jordy, Director

U.S. Department of Energy

ER-30, GTN

Washington, DC 20545

G. J. Judge

U.S. Department of Energy

EH-1, FORS

Washington, DC 20585

R. F. Kendall

U.S. Department of Energy

Bartlesville Energy Research Center

P.O. Box 1398

Bartlesville, OK 74005
H. -J. Klimisch

BASF Aktiengesellschaft

Abteilung Toxikologie, Z470

D-6700 Ludwigshafen

FEDERAL REPUBLIC OF

GERMANY

J. P. Knight

U.S. Department of Energy

Olfice of Safety Appraisals

EH-33, GTN

Washington, DC 20545

K. D. Knight

U.S. Department of Energy

EG-24

Washington, DC 20545

R. T. Kratzke

U.S. Department of Energy

EH-131, GTN

Germantown, MD 20545

T. Kumatori, Director

National institute of

Radiological Sciences

9-1, Anagawa-4-chome

Chiba-shi 260

JAPAN

R. F. Laitano

ENEA - CRE Casaccia

Casella Postale 2400

I-00100 Roma

ITALY

J. R. A. Lakey, Director Department of Nuclear Sciences \& Technology

Royal Naval College,

Greenwich

London SE10 9NN

ENGLAND

Li De-Ping

Professor and Director of North

China Institute of Radiation

Protection, NMI

Tai-yuan, Shan-Xi

THE PEOPLE'S REPUBLIC OF

CHINA

Librarian

Brookhaven National

Lahoratory

Research Library, Reference

Upton, Long Island, NY 11973
Librarian

Centre d'Etudes

Nucléaires de Saclay

P.O. Box 2, Saclay

Fig-sur-Yvette (S\&O)

FRANCE

\author{
Librarian \\ Colorado State University \\ Documents Department-The \\ Libraries \\ Ft. Collins, CO 80523
}

Librarian
CSIRO
314 Albert

314 Albert Street

P.O. Box 89

East Melbourne, Victoria

AUSTRALIA

Librarian

CSIRO

Div. of Atmospheric Research Station Street

Aspendal, Victoria 3195

AUSTRALIA

Librarian

Electric Power Research Institute

3412 Hillview Avenue

P.O. Box 10412

Palo Alto, CA 94303

Librarian

World Health Organization

$\mathrm{HCS} / \mathrm{EHE}$

$\mathrm{CH}-1211$ Geneva 27

SWITZERLAND

Librarian

University of Washington

Health Sciences Library, SB-55

Seattle, WA 98195

Librarian

Kernforschungzentrum

Karlsruhe

Institut fur Strahlenbiologie

Postfach 3640

D-75 Karisruhe 1

FEDERAL REPUBLIC OF

GERMANY 
Librarian

University of California,

Lawrence Livermore National Laboratory

Technical Information Dept., L-3

P.O. Box 808

Livermore, CA 94550

Librarian

Los Alamos National Laboratory

Report Library, MS P364

P.O. Box 1663

Los Alamos, NM 87545

Librarian

Max-Planck-Institut für

Biophysics

Forstkasstrasse

D-6000 Frankfurt/Main

FEDERAL REPUBLIC OF

GERMANY

Librarian

Ministry of Agriculture,

Fisheries \& Food

Fisheries Laboratory

Lowestoft, Sulfolk NR33 OHT

ENGLAND

Librarian

National Institute of

Radiological Sciences

9-1, Anagawa-4-chome

Chiba-shi 260

JAPAN

Librarian

Washington State University

Pullman, WA 99164-6510

Library

Atomic Energy Commission

Riso, Roskilde

DENMARK

Library

Atomic Energy Commission of

Canada, Ltcł.

Whiteshell Nuclear Research

Establishment

Pinawa, Manitoba ROE 1 L0

CANADA
Library

University of Stockholm

Department of Meteorology

Arrhenius Laboratory

S-106 91 Stockholm

SWEDEN

Library

University of Chicago

Serials Department

(\# 80-170187)

1100 East 57 th Street

Chicago, IL. 60637

B. Lindeil

National Institute of Radiation

Protection

Fack S-10401

Stockholm 60

SWEDEN

Ma Fubang, Director and Chief Engineer

Institute of Atomic Energy

P.O. Box 275

Beijing

THE PEOPLE'S REPUBLIC OF CHINA

J. N. Maddox

U.S. Department of Energy

ER-73, GTN

Washington, DC 20545

J. R. Maher

U.S. Department of Energy

ER-65, GTN

Washington, DC 20545

C. R. Mandelbaum

U.S. Department of Energy

ER-32, GTN

Washington, DC 20545

A. M. Marko, Director

Atomic Energy Commission of

Canada, Ltd.

Biology and Health Physics

Division

Chalk River Nuclear

Laboratories

P.O. Box 62

Chalk River, Ontario KOJ $\uparrow \mathrm{JO}$

CANADA
S. Marks

Radiation Effects Research

Foundation, Hijiyama Hall

5-1 Hijiyama Park

Minami-Ku

Hiroshima 732

JAPAN

P.O. Matthews

U.S. Department of Energy

P.O. Box A

Ajken, SC 29802

R. A. Mayes

U.S. Department of Energy

Chicago Operations Office

9800 South Cass Avenue

Argonne, IL 60439

R. C. McCall

Stanford Linear Accelerator

P.O. Box 4349

Stanford, CA 94305

H. M. McCammon

U.S. Department of Energy

ER-75, GTN

Washington, DC 20545

R. O. McClellan, President

Chemical Industry Institute of Toxicology

P.O. Box 12137

Research Triangle Park, NC 27709

W. T. Mee

$T-12$

P.O. Box $Y$

Oak Ridge, TN 37830

C. B. Meinhold

Radiological Sciences Division Bldg. $703 \mathrm{M}$

Brookhaven National Laboratory

Upton, Long Lsland, NY 11973

M. L. Mendelsohn

University of California

Biomedical and Environmental Research Program

Lawrence Livermore National Laboratory, L-452

P.O. Box 5507

Livermore, CA 94550 


C. Miller
P.O. Box 180
Watermill, NY 11976
W. A. Mills
Oak Ridge Associated
Universities
Committee on Interagency
Radiation Research \&
Policy Coordination (CIRRPC)
to19 19th Street, NW
Suite 700
Washington, DC 20036
H. J. Moe
Argonne National Laboratory
9700 South Cass Avenue
Argonne, 1 L 60439
D. W. Moeller
Harvard School of Public
Health
677 Huntington Avenue
Boston, MA 02115
D. R. Monti
U.S. Department of Energy
ER-14, GTN
Washington, DC 20545
F. A. Morris
Battelle - Seattle
4000 NE 41 st Street
Seattie, WA 98105
D. O. Moses
U.S. Department of Energy
EH-23, GTN
Washington, DC 20545
W. D. Moss
Los Alamos National
Laboratory
Group HSE9, MS-484
P.O. Box 1663
Los Alamos, NM 87545
S. M. Nealey
Battelle - Seattle
4000 NE 41 st Street
Sealtle, WA 98105

\author{
R. A. Neff \\ Monsanto Research Corp. \\ Mound Laboratory \\ P.O. Box 32 \\ Miamisburg, $\mathrm{OH} 45342$ \\ D. R. Nelson \\ U.S. Department of Energy \\ Office of Safety Policy \\ and Standards \\ EH-352 \\ Washington, DC 20545
}

N. S. Nelson

U.S. Environmental Protection Agency

Office of Radiation Programs,

ANR-461

$401 \mathrm{M}$ Street, SW

Washington, DC 20460

J. C. Nénot, Deputy Director

Département de Protection

Centre d' Etudes Nucléaires

BP No. 6

F-92260 Fontenay-aux-Roses

FRANCE

\section{P. Nettesheim \\ National Institutes of Environmental Health Sciences \\ Research Triangle Park, NC 27711}

S. M. Neuder

U.S. Nuclear Regulatory Commission

Mail Stop NL-007

Washington, DC 20555

W. R. Ney, Executive Director National Council on Radiation Protection and Measurements 7910 Woodmont Avenue Suite 1016

Washington, DC 20014

U.S. Nuclear Regulatory Commission

Advisory Committee on Reactor Safeguards

Washington, DC 20555
M. J. O'Brien

University of Washington

Radiation Safety Office, GS-05

Seattle, WA 98195

D. P. O'Neil

Argonne National Laboratory 9700 South Cass Avenue

Argonne, IL 60439

W. S. Osburn, Jr.

U.S. Department of Energy

ER-75, GTN

Washington, DC 20545

Pan Zi-Qiang

Bureau of Safety, Protection and Health

Ministry of Nuclear Industry

P.O. Box 2102

Beijing

THE PEOPLE'S REPUBLIC OF CHINA

H. G. Paretzke

GSF Institut für Strahlenschutz Ingolstadter Landstrasse 1

D-8042 Neuherberg

FEDERAL REPUBLIC OF

GERMANY

N. Parmentier

Centre d'Etudes Nucléaires

Département de Protection Sanitaire

BP No. 6

F-92260 Fontenay-aux-Roses

FRANCE

D. C. Parzyck

Oak Ridge National Laboratory

P.O. Box 2008

Oak Ridge, TN 37831-6103

O. Pavlovski

Institute of Biophysics

Ministry of Public Health

Givopisnaya 46

Moscow D-182

USSR 


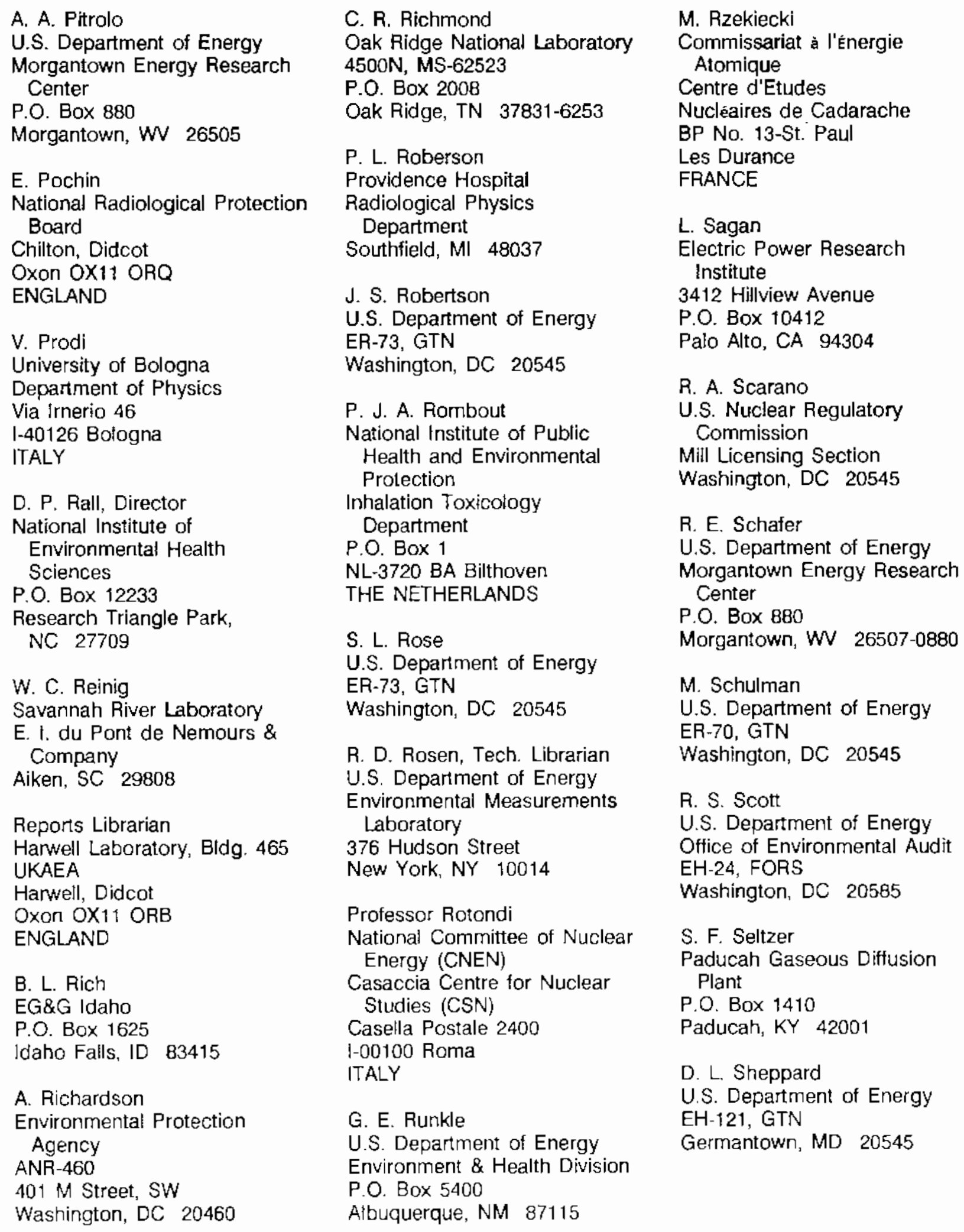

M. Rzekiecki

Commissariat à l'énergie

Atomique

Centre d'Etudes

Nucléaires de Cadarache

Les Durance

L. Sagan

lectric Power Research

P.O. Box 10412

R. A. Scarano

U.S. Nuclear Regulatory

Commission

Mitl Licensing Section

R. E. Schafer

U.S. Department of Energy

Energy Research

P. Box 880

M. Schulman

U.S. Department of Energy

ER-70, GTN

R. S. Scott

U.S. Department of Energy

Office of Environmental Audit

-24, FORS

S. F. Seltzer

Paducah Gaseous Diffusion

P.O. Box 1410

D. L. Sheppard

S.S. Department of Energy

EH-121, GTN

U.S. Department of Energy

P.O. Box 5400

Albuquerque, NM 87115 
R. Shikiar

Battelle - Seattle

4000 NE 41st Street

Seattle, WA 98105

P. H. Sitverman

University of California

Lawrence Berkeley Laboratory

Donner Laboratory, Room 466

Berkeley, CA 94720

W. J. Silvey

U.S. Department of Energy

PE-2, FORS

Washington, DC 20585

C. S. Sims

Oak Ridge National Laboratory

$X-10$, Building 7710, Room 101

P.O. Box 2008

Oak Ridge, TN 37831-6379

W. K. Sinclair, President

National Council on Radiation

Protection

7910 Woodmont Avenue

Suite 1016

Bethesda, MD 20814

D. H. Slade

U.S. Department of Energy

ER-74, GTN

Washington, DC 20545

D. A. Smith

U.S. Department of Energy

ER-72, GTN

Washington, DC 20545

H. Smith

International Commission on

Radiological Protection

P.O. Box 35

Didcot

OxOn OX11 ORJ

ENGLAND

J. Snow

U.S. Department of Energy

ER-6, FORS

Washington, DC 20585

R. G. Stafiord

Los Alamos National

Laboratory

MS E584

P.O. Box 1663

Los Alamos, NM 87545
J. N. Stannard

University of California

17441 Plaza Animado \#132

San Diego, CA 92128

R. W. Starostecki

U.S. Department of Energy

NE-A0, GTN

Washington, DC 20545

J. W. Stather

National Radiological Protection Board

Building 383

Chilton, Didcot

OXOn OX11 ORO

ENGLAND

E. T. Still

Kerr-McGee Corporation

P.O. Box 25861

Oklahoma City, OK 73125

M. J. Suess, Regional Officer for Environmental Hazards

World Health Organization

8, Scherfigsvej

DK-2100 Copenhagen

DENMARK

Sun Shi-quan, Head Radiation-Medicine

Department

North China Institute of Radiation Protection, MNI

P.O. Box 120

Tai-yuan, Shan-Xi

THE PEOPLE'S REPUBLIC OF CHINA

J. Swinebroad

U.S. Department of Energy

PE-24, GTN

Washington, DC 20545

J. Swinebroad

U.S. Department of Energy

$\mathrm{EH}-12$, GTN

Washington, DC 20545

Technical Information Service

Savannah River Laboratory

Room 773A

E. I. du Pont de Nemours \& Company

Aiken, SC 29801
T. Terasima, Director-General

National Institute of

Radiological Sciences

941. Anagawa-4-chome

Chiba-shi 260

JAPAN

J. G. Themelis

U.S. Department of Energy

Albuquerque Operations

Office

P.O. Box 5400

Albuquerque, NM 87115

J. W. Thiessen

Radiation Effects Research

Foundation

5-2 Hijiyama Park

Minami-Ku

Hiroshima 732

JAPAN

R. G. Thomas

U.S. Department of Energy

ER-72, GTN

Washington, DC 20545

R. H. Thomas

Lawrence Berkeley Laboratory

University of California

Occupational Health Division

Bidg. 50A-5104

Berkeley, CA 94720

W. T. Thorton

Occupational Safety Branch

P.O. Box A

Aiken, SC 29801

R. E. Toohey

Division of Biological and Medical Research

Argonne National Laboratory (201-231)

9700 South Cass Avenue

Argonne, IL. 60439

F. Tooper

U.S. Department of Energy

Operational Standards and

Analysis Division

Office of Safety Policy

and Standards

Washington, DC 20545 


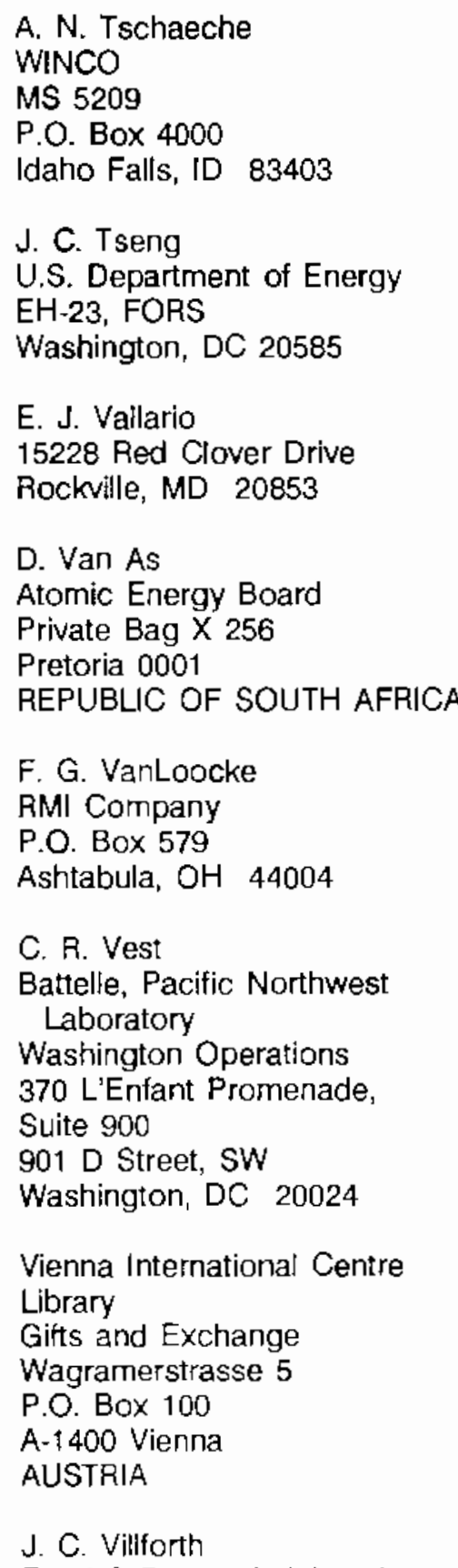

Food \& Drug Administration Bureau of Radiological Health Rockville, MD 20852

G. J. Vodapivc

U.S. Department of Energy

Schenectady Naval Reactors Office

P.O. Box 1069

Schenectady, NY 12301
G. L. Voelz

Los Alamos National

Laboratory

MS-K404

P.O. Box 1663

Los Alamos, NM 87545

B. W. Wachholz

National Cancer Institute

Radiation Effects Branch

8000 Rockville Pike

EPN, Room 530

Bethesda, MD 20892

E. R. Wagner

Portsmouth Gaseous Diffusion

Plant

Martin Marietta Energy Systems

P.O. Box 628

Piketon, $\mathrm{OH} 45661$

ค. A. Waiters

Los Alamos National

Laboratory

MS-A114

P.O. Box 1663

Los Alamos, NM 87545

Wang Hengde

North China Institute of

Radiation Protection

P.O. Box 120

Tai-yuan, Shan-Xi

THE PEOPLE'S REPUBLIC OF CHINA

Wang Ruifa, Associate Director Laboratory of industrial Hygiene

Ministry of Public Health

2 Xinkang Street

P.O. Box 8018

Deshengmenwai, Beijing 100088

THE PEOPLE'S REPUBLIC OF CHINA

Wang Yibing

North China Institute of

Radiation Protection

P.O. Box 120

Taj-yuan, Shan-Xi

THE PEOPLE'S REPUBLIC OF

CHINA
G. Warren

Stanford Linear Accelerator

P.O. Box 4349

Stanford, CA 94305

Wei Lü-Xin

Laboratory of Industrial

Hygiene

Ministry of Public Health

2 Xinkang Street

Deshengmenwai, Beijing

THE PEOPLE'S REPUBLIC OF CHINA

W. W. Weyzen

Electric Power Research

institute

3412 Hillview Avenue

P.O. Box 10412

Palo Aito, CA 94303

H. D. Whitehead

Oak Ridge Gaseous Diffusion Plant

P.O. Box P

Oak Ridge, TN 37831

E. R. Williams

U.S. Department of Energy 1000 independence Ave., SW

Washington, DC 20585

G. A. Wiltsee, Director

Univ. of North Dakota Energy Research Center

Box 8213, Univ. Station

Grand Forks, ND 58202

B. C. Winkler, Director Licensing

Raad Op Atomic

Atoomkrag Energy Board

Privaatsk X 256

Pretoria 0001

REPUBLIC OF SOUTH AFRICA

F. E. Witmer

U.S. Department of Energy

EH-131, GTN

Washington. DC 20545

F. J. Wobber

U.S. Department of Energy

14 Goshen Court

Gaithersburg, MD 20879-4403 


R. W. Wood
U.S. Department of Energy
PTRD, OHER
ER-74, GTN
Washington, DC 20545
M. E. Wrenn
Environmental Radiation \&
Toxicology Laboratory
956 West Levoy, Suite 100
Salt Lake City, UT 84123
Wu De-Chang
Institute of Radiation Medicine
27 Tai Ping Road
Beijing
THE PEOPLE'S REPUBLIC OF
CHINA
Xie Zi, Senior Engineer Scientific Secretary of Rådiation Protection Laboratory Institute of Atomic Energy P.O. Box 275
Beijing
THE PEOPLE'S REPUBLIC OF CHINA

\section{R. E. Yoder \\ Science Applications International Corporation 20030 Century Blvd., Suite 201 Germantown, MD 20874}

Zhu Zhixian
University of California
Laboratory for Energy-Related
Health Research
Davis, CA 95616
P. L. Ziemer
Purdue University
School of Health Sciences
West Lafayette, IN 47907
ONSITE
DOE Richland Operations
Olfice (12)
D. T. Evans
T. R. Fitzsimmons
E. S. Goldberg
R. B. Goranson
R. D. Izatt
E. C. Norman

M. W. Tiernan

G. R. Yesberger (5)

Iri-Cities University Center (2)

J. Cooper, Librarian

B. Valett

Hanford Environmental Health

(2)

D. B. Breitenstein
R. D. Gilmore

Westinghouse Hanford Co. (5)

W. M. Jacobi

R. E. Lerch

H. E. McGuire

R. M. Mitchell

D. E. Simpson

Pacific Northwest Laboratory

(195)

M. S. Abashian

R. C. Adams

T. L. Anderson

L. H. Arnold

G. F. Athey

R. W. Baalman

J. F. Bagley

W. J. Bair (15)

D. A. Baker

E. G. Baker

W. W. Ballard

C. M. Berkowitz

J. S. Bogard

L. W. Brackenbush

P. E. Bramson (5)

R. D. Brockhaus

J. B. Brown

J. W. Buck

B. A. Bushaw

B. D. Cannon

D. B. Cearlock

T. D. Chikalla

T. T. Claudson

F. T. Cross

J. L. Daniel (5)

D. H. Denham

J. T. Denovan

P. G. Doctor

J. C. Doran

D. W. Dragnich

J. G. Droppo

J. S. Durham

R. M. Ecker
P. A. Eddy

C. E. Elderkin

G. W. R. Endres

S. L. English

S. K. Ennor (5)

L. G. Faust (10)

D. R. Fisher

J. J. Fix

W. C. Forsythe

A. A. Fox

D. R. Friedrichs

J. E. Gebhart

G. K. Gerke

J. A. Glissmeyer

M. J. Graham

L. K. Grove

D. E. Hadlock

J. M. Hales (5)

R. Harty

P. C. Hays

E. E. Hickey

D. P. Higby

K. A. Higley

D. E. Hilmas

G. R. Hoenes

C. D. Hooker

B. L. Hoopes

D. G. Huizenga

K. L. Imhoff

E. A. Jacobson

R. E. Jaquish

J. R. Johnson

B. V. Johnston

K. L. Jones

B. J. Kelman

W. E. Kennedy, Jr.

L. J. Kirby

W. W. Laity

D. A. Lamar

J. L. Latkovich

J. A. Leonowich

J. A. MacLellan

J. B. Martin

G. A. McAtee

W. D. McCormack

E. J. McCoy

J. C. McDonald

D. A. McNeill

S. E. Merwin

T. B. Miley

S. D. Miller

J. Mishima

E. B. Moore, Jr.

W. D. Moss

1. C. Nelson

P. L. Oberlander

R. A. Owens

H. E. Palmer 
M. A. Parkhurst

R. A. Peloquin

R. W. Perkins

W. T. Pennell (5)

A. M. Platt

K. M. Poad

D. W. Raichart

J. V. Ramsdell

L. A. Rathbun

J. R. Raymond

W. D. Reese

R. I. Scherpelz

R. G. Schreckhise

W. B. Scott

J. M. Selby (5)

M. R. Sikov
C. L. Simpson

D. R. Simpson

D. R. Sisk

J. K. Soldat

R. D. Stenner

J. G. Stephan

G. A. Stoetzel

J. A. Stottlemyre

J. L. Straalsund

D. L Strenge

C. M. Stroud

M. J. Sula

M. F. Sullivan

A. S. Tabatabaj (5)

K. L. Swinth

J. E. Tanner
T. S. Tenforde (2)

R. J. Traub

L. M. Valdez

B. E. Vaughan

M. B. Walter

G. Whelan

T. J. Whitaker

J. S. Wilbur

R. E. Wildung

W. R. Wiley

W. G. Woodruff

Health Physics Department Library

L.ife Sciences Library (2)

Publishing Coordination

Technical Report Files (5) 